\title{
Investigation of Energy Consumption and Characteristics of a Battery Electric Vehicle
}

Jacob Hill

Follow this and additional works at: https://researchrepository.wvu.edu/etd

\section{Recommended Citation}

Hill, Jacob, "Investigation of Energy Consumption and Characteristics of a Battery Electric Vehicle" (2017). Graduate Theses, Dissertations, and Problem Reports. 5804.

https://researchrepository.wvu.edu/etd/5804

This Thesis is protected by copyright and/or related rights. It has been brought to you by the The Research Repository @ WVU with permission from the rights-holder(s). You are free to use this Thesis in any way that is permitted by the copyright and related rights legislation that applies to your use. For other uses you must obtain permission from the rights-holder(s) directly, unless additional rights are indicated by a Creative Commons license in the record and/ or on the work itself. This Thesis has been accepted for inclusion in WVU Graduate Theses, Dissertations, and Problem Reports collection by an authorized administrator of The Research Repository @ WVU. For more information, please contact researchrepository@mail.wvu.edu. 


\title{
INVESTIGATION OF ENERGY CONSUMPTION AND CHARACTERISTICS OF A BATTERY ELECTRIC VEHICLE
}

\author{
Jacob Hill
}

Thesis submitted

to the Benjamin Statler College of

Engineering and Mineral Sources

at West Virginia University

in partial fulfillment of the requirements for the degree of

Master of Science in

Mechanical Engineering

Ross Ryskamp, Ph.D., Chair

Scott Wayne, Ph.D.

Kenneth Means, Ph.D.

Department of Mechanical and Aerospace Engineering

Morgantown, West Virginia

2017

Keywords: Battery Electric Vehicle, Energy Consumption, Fuel Economy, Emissions Copyright 2017 Jacob Hill 


\section{A BSTRACT}

\section{INVESTIGATION OF ENERGY CONSUMPTION AND CHARACTERISTICS OF A BATTERY ELECTRIC VEHICLE}

\section{by Jacob Hill}

Electric vehicles are becoming more popular for manufacturers as emissions restrictions for internal combustion engine (ICE) powered vehicles become tighter. The primary objective of this study was to characterize a battery electric vehicle (BEV) with respect to energy consumption as well as emissions from the battery or propulsion system. It was also desired to compare the BEV to internal combustion engine (ICE) powered vehicles in its class considering greenhouse gases, as well as energy economy, miles per gallon (MPG), and miles per gallon equivalent (MPGge) efficiency.

Tesla is a forerunner in BEVs. The approach they took in making their battery pack is different from any other BEV manufacturer. The Tesla battery pack or energy storage system (ESS) is constructed out of thousands of 18650 style lithium ion battery cells through a partnership with Panasonic. The tooling for these battery cells was already established which keeps costs down. This unique design allows Tesla to have one of the cheapest ESS cost per kilo-watt-hour of any manufacturer.

A 2013 Tesla Model S P85 was exercised on a chassis dynamometer along with on road testing consisting of a CAFEE Morgantown Route and Bruceton Mills Route to characterize its energy consumption. Energy consumption data was measured with a current clamp on the positive high voltage battery cable and voltage probes contacting the high voltage busbar. Vehicle speed was recorded from the chassis dynamometer and a global positioning system (GPS) when operating the vehicle on-road.

Battery electric vehicles do not have a tailpipe and thus do not produce tailpipe emissions like an internal combustion engine powered vehicle does. However; it was desired to investigate if the ESS or propulsion system emitted any gases. A sample manifold was fabricated to mount to the battery pack vent. Samples were taken with and without a sample pump during charging, highway driving, and dynamometer testing. These samples were analyzed with a Fourier transform infrared (FTIR) analyzer and a gas chromatograph (GC) analyzer.

A bench top experiment was devised in an attempt to determine the source of the gases emitted from the vehicle's ESS. Six Tesla 18650 style battery cells were purchased and installed into a test rig. These cells were then charged and discharged to determine if there was any gases emitted from the cells themselves. Exercising the battery cells outside of the ESS did not produce any of the emissions observed while examining the ESS on the vehicle. Through these experiments it was concluded that the gases emitted from the ESS on the vehicle were a result of damaged cells or deterioration of other construction materials. Furthermore, it was also possible that the ESS was acting as a thermal pump due to ambient temperature changes within the ESS. 


\section{ACKNOWLEDGMENTS}

The author wishes to thank Dr. Ross Ryskamp for his mentorship and constant willingness to offer help and feedback. This opportunity was made possible with his guidance.

Thank you to Dr. Wayne for his support and mentorship throughout the Formula SAE program. The technical writing and hands on experience provided has been invaluable.

Dr. McKenzie, thank you for always being just a phone call away, and helping me achieve my academic goals.

Pat and Pam, your dedication to my education and constant support has not gone unnoticed. I will always be grateful for the examples you set for me throughout the years of my education.

To my loving family, thank you for always being there and encouraging me to pursue my dreams.

Lastly, I would like to thank Mr. Beam, you were always there for me whenever I needed a morale booster. 


\section{TABLE OF CONTENTS}

ABSTRACT

ACKNOWLEDGMENTS

TABLE OF CONTENTS.

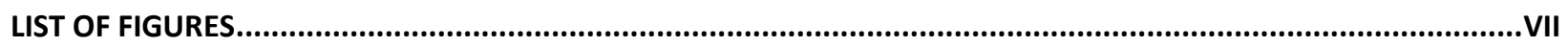

LIST OF TABLES

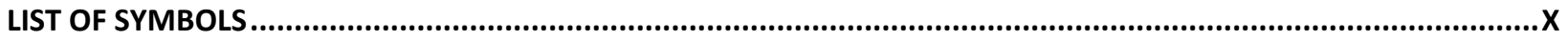

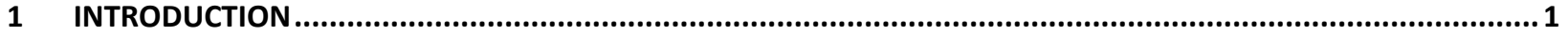

1.1 TEST VEHICLE

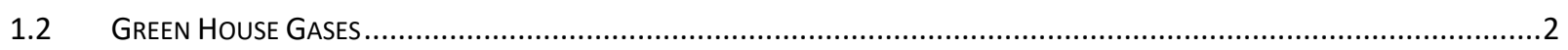

1.3 Comparison of Electric VehICLE To LUXURy Sedans In Market ..................................................................

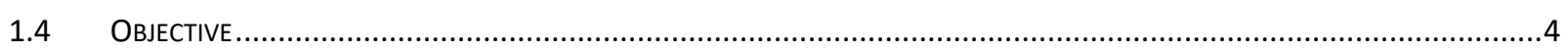

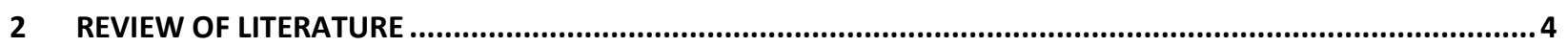

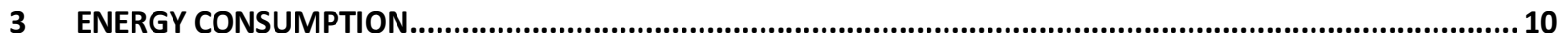

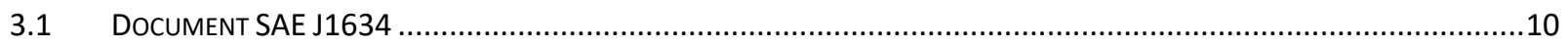

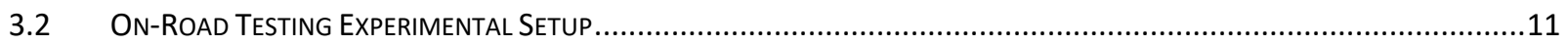

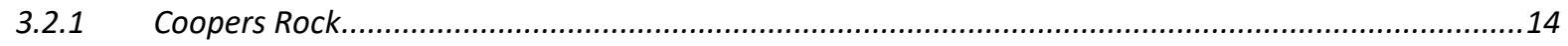

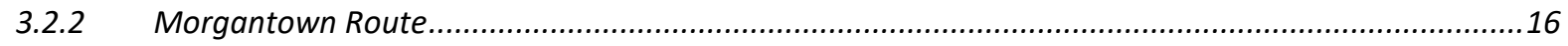

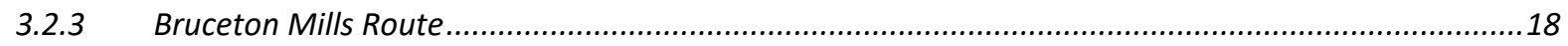

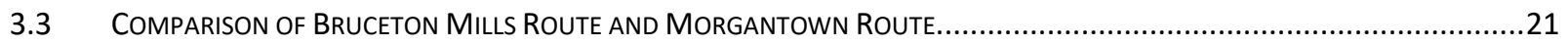

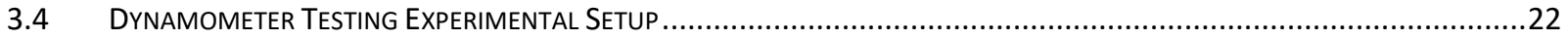

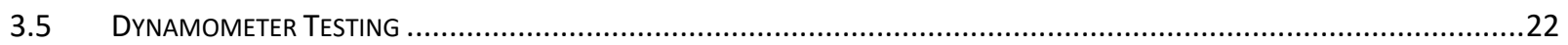

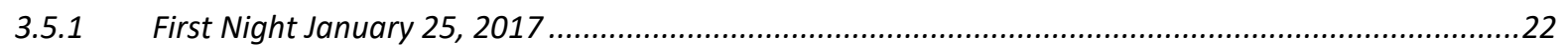

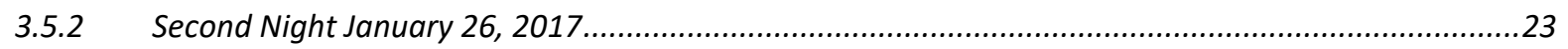

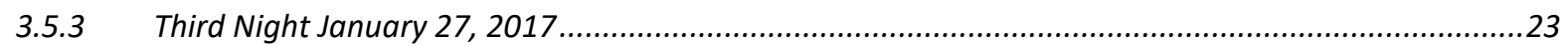

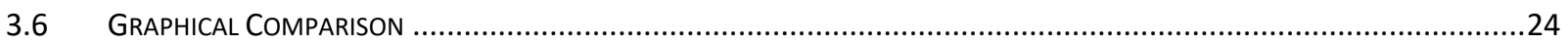




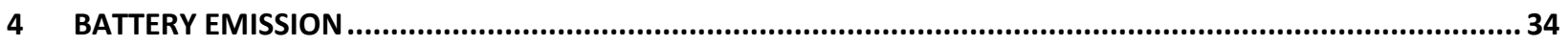

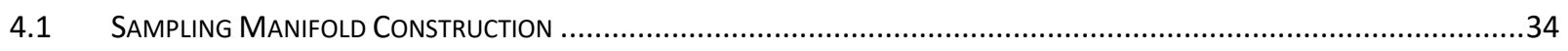

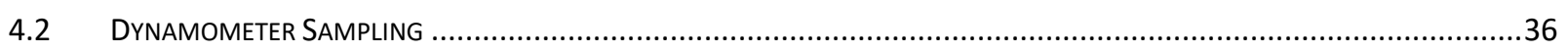

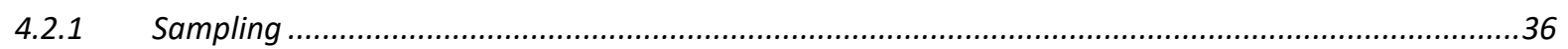

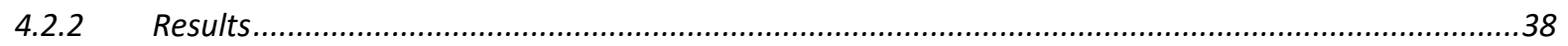

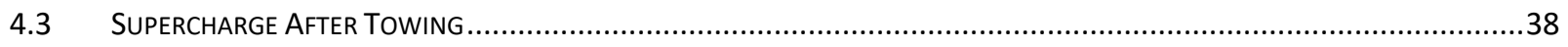

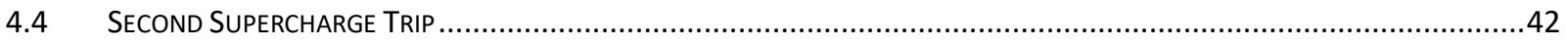

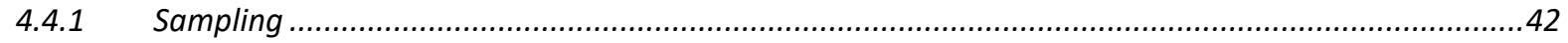

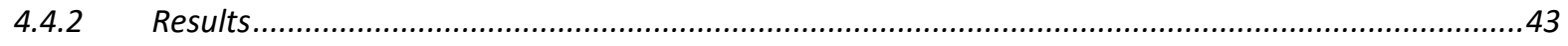

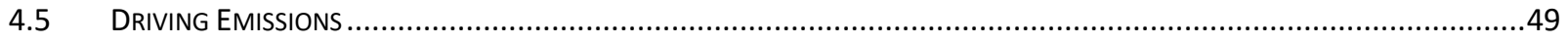

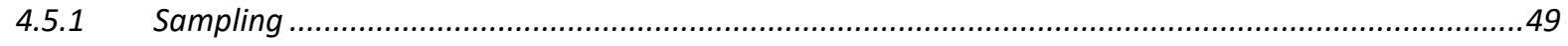

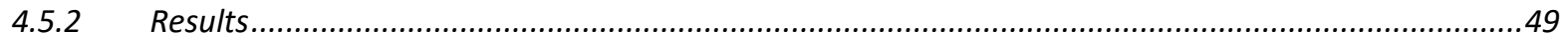

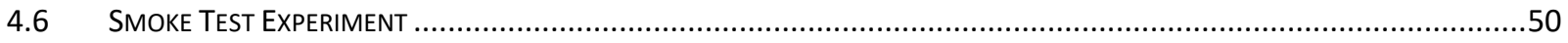

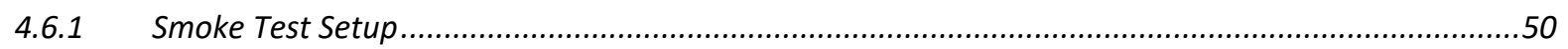

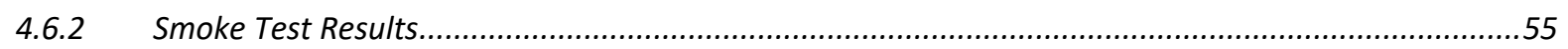

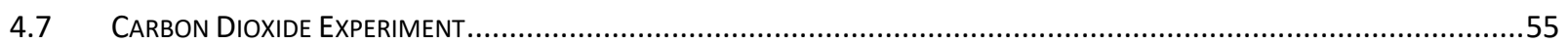

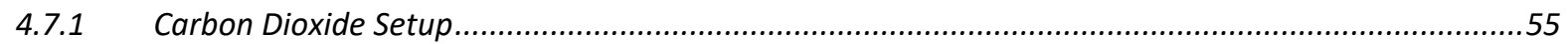

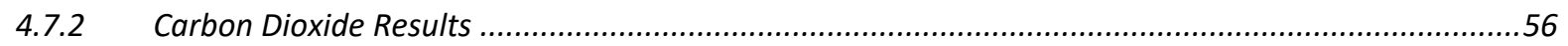

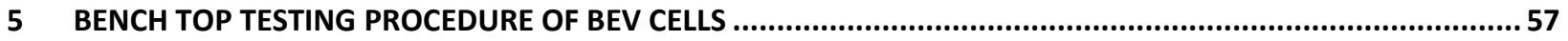

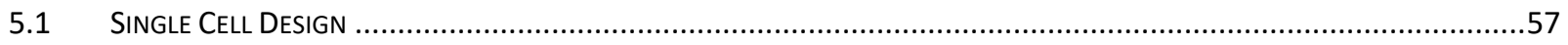

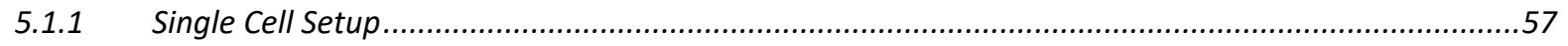

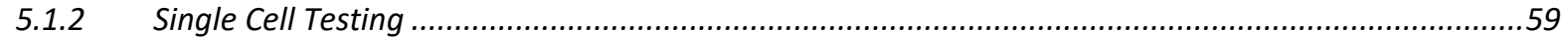

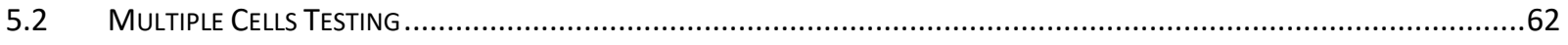

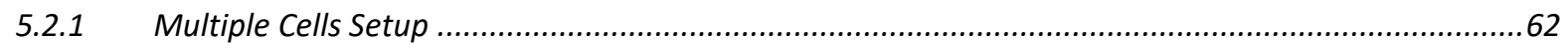

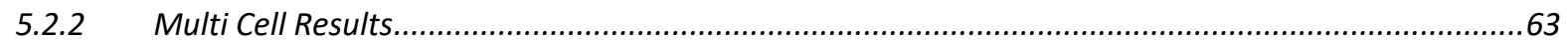

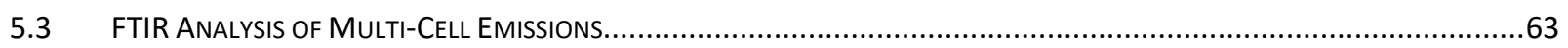

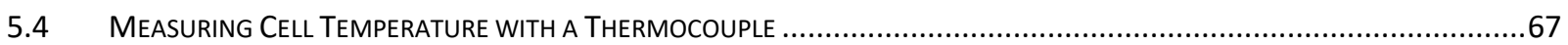




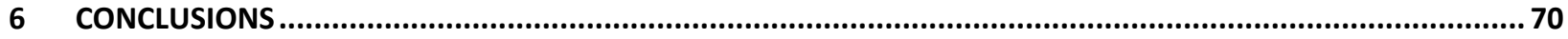

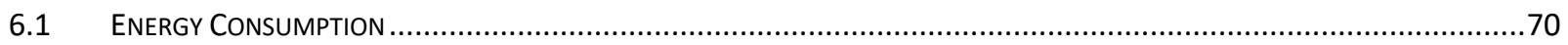

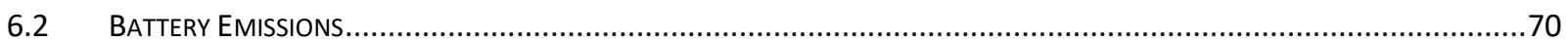

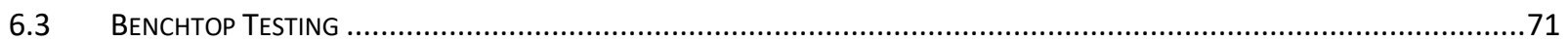

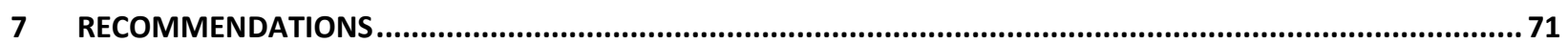

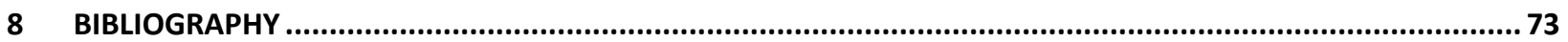

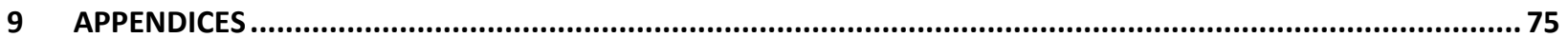

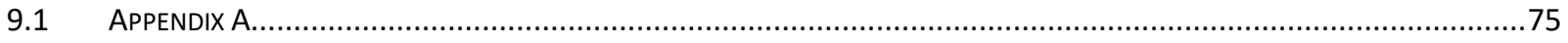

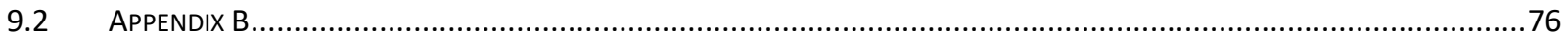

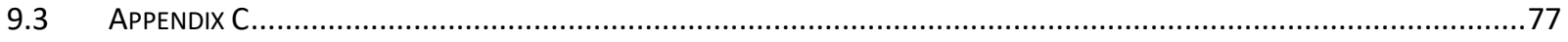

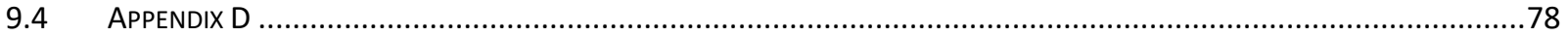




\section{LIST OF FIGURES}

Figure 1 Tesla Model S, Courtesy Kelly Blue Book .......................................................................... 2

Figure 2 Left: The Differential Probe. Right: The Current Clamp.................................................... 11

Figure 3 AEMC Instruments Model MR 521 AC/DC Current Probe .................................................... 12

Figure 4 Tektronix P5205A 100MHz, High Voltage Differential Probe ................................................13

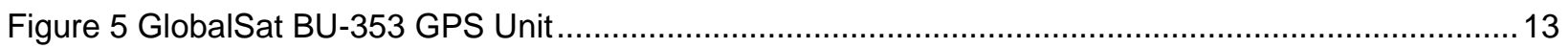

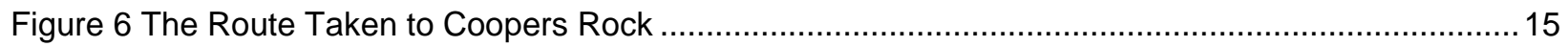

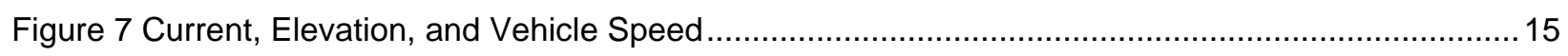

Figure 8 Residential Service Rate for MonPower Morgantown, WV ..................................................... 16

Figure 9 The Morgantown Route Displayed on a Map …............................................................... 17

Figure 10 Current, Altitude, and Vehicle Speed for the Morgantown Route........................................ 18

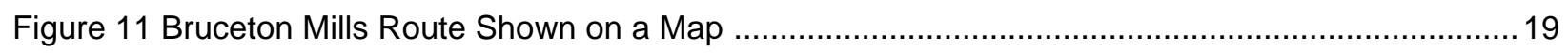

Figure 12 Bruceton Mills Route; from VETL to Bruceton Mills...........................................................20

Figure 13 Bruceton Mills Route; from Bruceton Mills to VETL.......................................................2 20

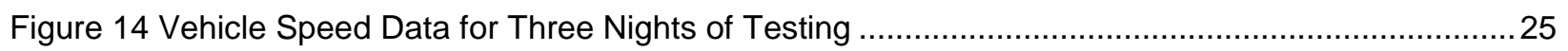

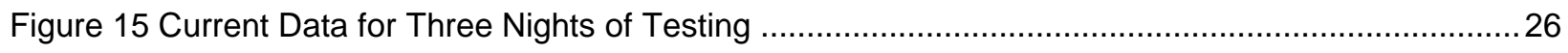

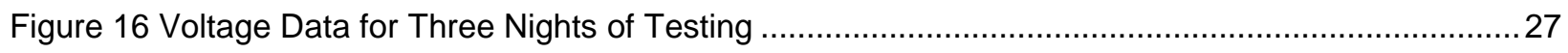

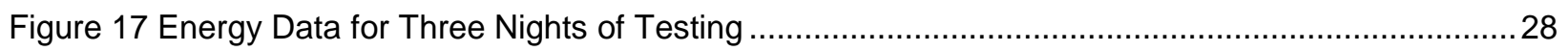

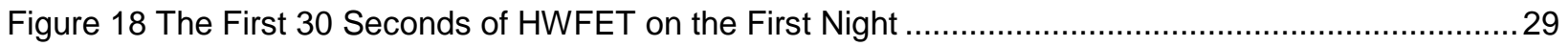

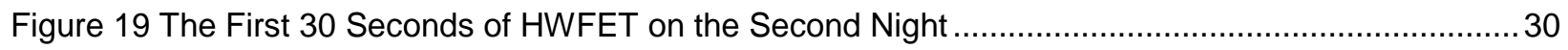

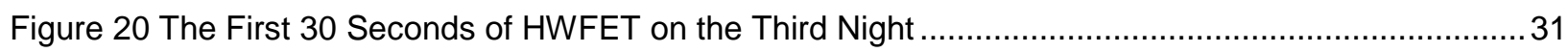

Figure 21 Edc Uncertainty Error Plot for US06 on the Third Night of Testing ...................................... 33

Figure 22 Zoomed in Edc Uncertainty Error Plot for US06 on the Third night of Testing ......................... 34

Figure 23 The ESS Vent Covered, Left. Uncovered, Right ........................................................... 35

Figure 24 Clockwise from Top Left: The Sample Manifold and Cover. The Inside of the Sample Manifold.

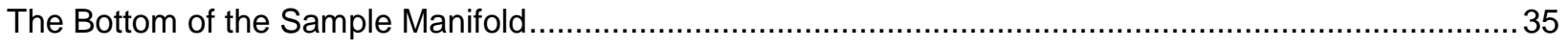

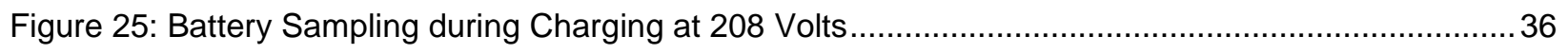

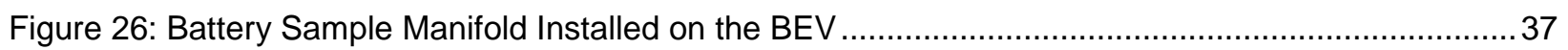


Figure 27: BEV Secured to the Chassis Dynamometer

Figure 28 Supercharging the BEV While on the Tow Truck 39

Figure 29 Main Display Indicating that the BEV is Supercharging ..................................................... 39

Figure 30 Rotameter Connected to Sample Manifold as ESS Flows ................................................. 40

Figure 31 Ambient Carbon Monoxide vs. Battery Carbon Monoxide ................................................... 40

Figure 32 Ambient Carbon Dioxide vs. Battery Carbon Dioxide ............................................................. 41

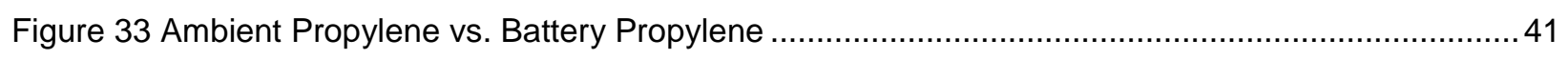

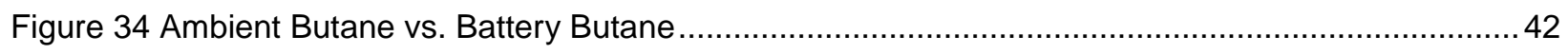

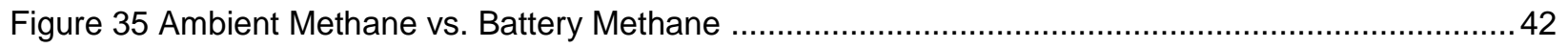

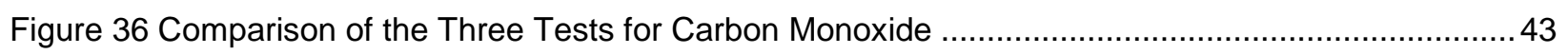

Figure 37 Comparison of the Three Tests for Carbon Dioxide ........................................................... 44

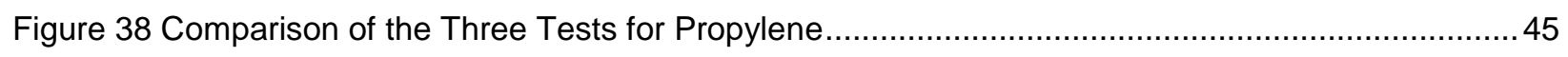

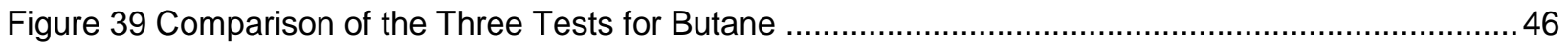

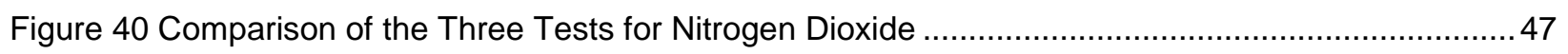

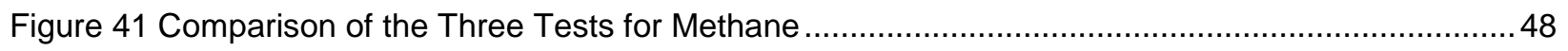

Figure 42 Left: Inflated Bag. Right: Deflated Bag ..................................................................... 50

Figure 43 C Clips Were Fabricated to Hold the Orange Diaphragm Valves Open.................................51

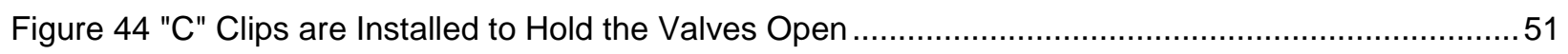

Figure 45 Manifold is Reinstalled with a Pressure Gauge to See if the Battery Pack Pressurizes ............52

Figure 46 Canister to Funnel Smoke into the Manifold................................................................. 53

Figure 47 Canister with Tube and Smoke Generator ................................................................. 53

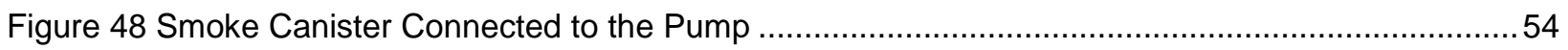

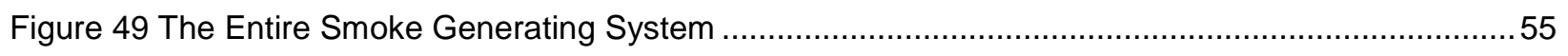

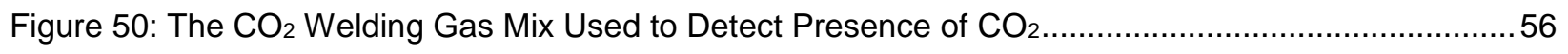

Figure 51: The DAQ Setup as well as the Box Containing the HoribaBE150 ....................................56

Figure 52 Top View of Enclosure Looking into the Test Chamber ...................................................59

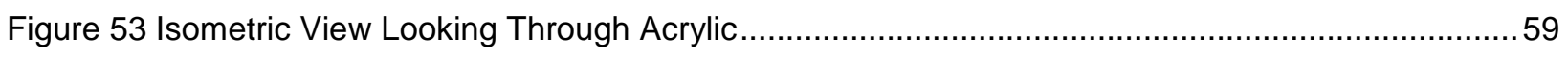

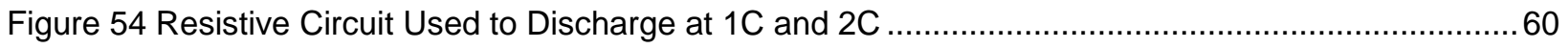


Figure 55 Left: The Sample Bag Connected to the Bulkhead. Right: The Single Battery Cell Enclosed...60 Figure 56 The Single Cell Sample Test 61

Figure 57 Digital Multi Meter Measuring the Voltage of the New Battery Configuration 62

Figure 58 Resistive Network Used to Discharge the Battery Pack ...................................................62

Figure 59 The Battery Pack Discharging While Connected to a Sample Bag ......................................63

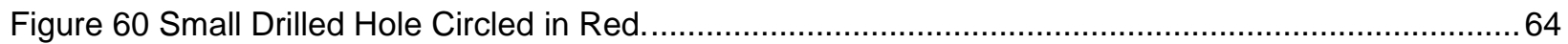

Figure 61 No Load is Placed on the Batteries. Sample is Taken as Control ......................................... 64

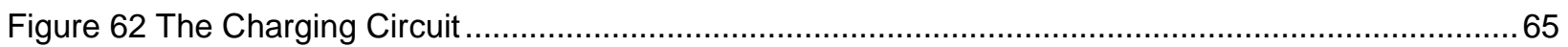

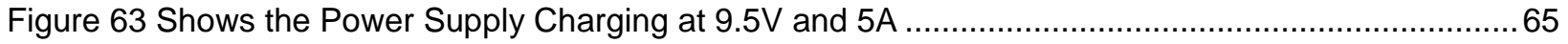

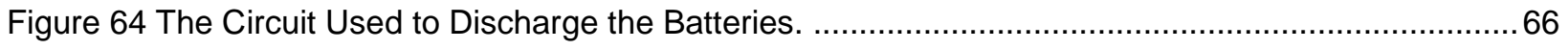

Figure 65 Shows No Discernable Differences Between the Control and the Sample ............................67

Figure 66 The Thermocouple is in Contact with the Battery Cell....................................................... 68

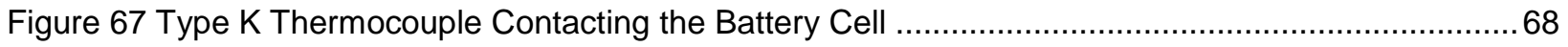

Figure 68 Left: Temperature Rise of a Battery Cell due to Discharge. Right: Temperature Rise of a Battery

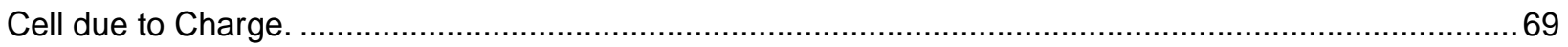

\section{LIST OF TABLES}

Table 1 Details for Each Leg of the Bruceton Mills Route ............................................................... 19

Table 2 MPGge and Trip Cost for the Four Federal Test Procedures .................................................2 23

Table 3 MPGge and Trip Cost for the Four Federal Test Procedures .....................................................2 23

Table 4 MPGge and Trip Cost for the Four Federal Test Procedures ...................................................24

Table 5 The Max Concentrations Detected of Each Gaseous Species..................................................48

Table 6 Shows the C-rates for a Panasonic NCR18650b battery cell.................................................57

Table 7 Resistive Load and Power Dissipation Needed to Discharge at Specified C-rates......................58 


\section{LIST OF SYMBOLS}

\begin{tabular}{|c|c|}
\hline Meaning & Symbol \\
\hline Air- Conditioning & $\mathrm{AC}$ \\
\hline Amp-hours & Ah \\
\hline Argonne National Lab & ANL \\
\hline Battery Electric Vehicle & BEV \\
\hline Carbon Dioxide & $\mathrm{CO}_{2}$ \\
\hline Carbon Monoxide & $\mathrm{CO}$ \\
\hline $\begin{array}{l}\text { Center for Alternative Fuels, Engines and } \\
\text { Emissions }\end{array}$ & CAFEE \\
\hline Computer Aided Design & CAD \\
\hline Current Interrupt Device & CID \\
\hline Data Acquisition & DAQ \\
\hline Direct Current & $\mathrm{DC}$ \\
\hline Direct Current Energy & Edc \\
\hline Electric Vehicle & $\mathrm{EV}$ \\
\hline Energy Storage System & ESS \\
\hline Fourier Transform Infrared & FTIR \\
\hline Gas Chromatograph & GC \\
\hline Global Positioning System & GPS \\
\hline Greenhouse Gas & GHG \\
\hline Heating, Ventilation and Air Conditioning & HVAC \\
\hline High Voltage & $\mathrm{HV}$ \\
\hline Kilo-watts & KW \\
\hline Liters per Minute & Ipm \\
\hline Lithium Ion & Li-ion \\
\hline Lower Heating Value & LHV \\
\hline
\end{tabular}




\begin{tabular}{|l|l|}
\hline Methane & CH4 \\
\hline Miles per Gallon Gasoline Equivalent & MPGge \\
\hline Miles per hour & MPH \\
\hline Milli-amp-hours & mAh \\
\hline Nickel Metal Hydride & NiMH \\
\hline Nitrogen Dioxide & NO2 \\
\hline Parts Per Million & ppm \\
\hline Positive Temperature Coefficient & PTC \\
\hline Room Temperature Vulcanizing & RTV \\
\hline Society of Automotive Engineers & SAE \\
\hline South West Research Institute & SwRI \\
\hline State of Charge & SOC \\
\hline State of Health & SoH \\
\hline The Greenhouse gases, Regulated Emissions, \\
and Energy use in Transportation Mode & GREET \\
\hline Universal Serial Bus & USB \\
\hline Vehicle and Engines Testing Laboratory & Wh \\
\hline Watt-hours & \\
\hline
\end{tabular}




\section{Introduction}

To reduce carbon emissions from internal combustion engine (ICE) powered vehicles, other methods of powering vehicles are being explored. Battery electric vehicles (BEV) are one such method that have become prevalent in recent years. Battery technology has progressed from relatively heavy lead-acid batteries to more compact, highly energy dense lithium-ion batteries providing vehicles more power available and a longer range at a lower curb weight. These technologies allow the consumer to plug in their vehicle at their residence and charge the batteries from the electrical grid, or at a public charging station.

Throughout the years several battery chemistries emerged as prominent on the market. These battery chemistries are: lead-acid, nickel metal hydride (NiMH) and lithium ion (Li-ion). The lead-acid battery is the least expensive battery chemistry; however, lead-acid technology has some drawbacks when compared to other battery chemistries available. Lead-acid battery packs are much heavier than $\mathrm{NiMH}$ and Li-ion by comparison. Another drawback is that the State of Charge (SOC) of the lead-acid battery must be below seventy percent in order to receive regenerative energy [1] [2].

The Li-ion battery has a higher energy density than $\mathrm{NiMH}$ batteries. The mass of a Li-ion battery pack is about half the mass of a NiMH pack and takes up twenty percent less volume. In a hybrid ICEelectric vehicle, a Li-ion battery pack has five percent better efficiency than an equivalent $\mathrm{NiMH}$ battery pack [3].

The battery packs of NiMH cells must have vents that open and close as needed to release gases as the $\mathrm{NiMH}$ batteries vent over their life cycle. Li-ion batteries on the other hand are sealed batteries, however the battery pack may have vents for thermal expansion. If Li-ion batteries vent, it is a one-time occurrence that is irreversible. Many li-ion batteries contain a current interrupt device (CID), once internal battery pressure gets too high the li-ion battery cell may vent and open the CID, breaking the internal circuit of the battery cell [3].

\subsection{Test Vehicle}

The test vehicle was a 2013 Tesla Model S, it is a battery electric vehicle [4]. The 85-kWh version, tested, produces 362 horsepower and 317 foot-pounds of torque. It has an estimated range of 300 miles 
at 55 miles per hour. The luxury sedan has a 0-60 mile per hour time of 4.4 seconds. Figure 1, below shows a picture of the vehicle.

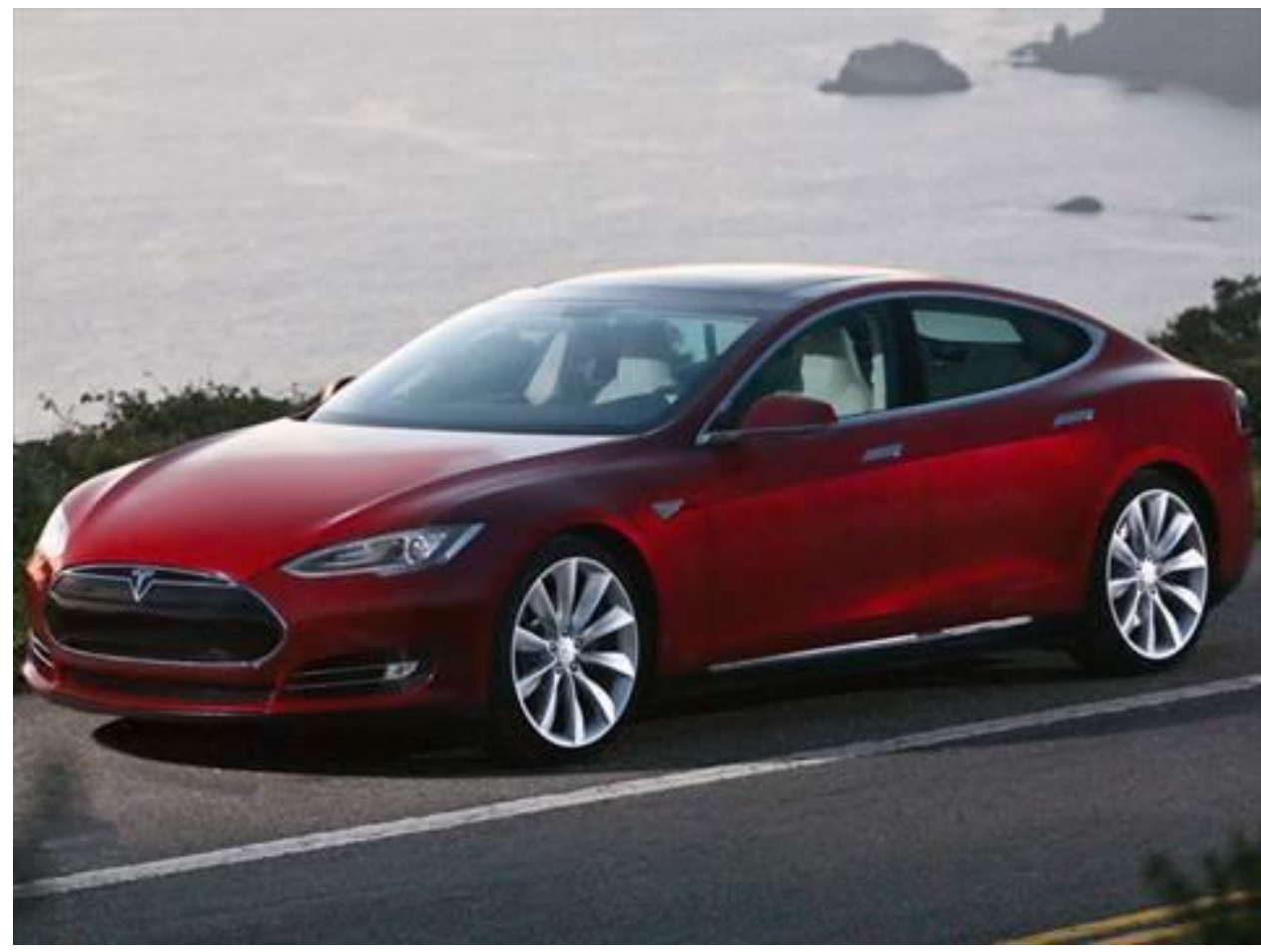

Figure 1 Tesla Model S, Courtesy Kelly Blue Book

\subsection{Green House Gases}

A major attraction to battery electric vehicles is that they produce no tailpipe emissions. Tailpipe emissions refer to gases that are produced as a byproduct of combusting a fossil fuel in an ICE. On average 19.6 pounds of carbon dioxide $\left(\mathrm{CO}_{2}\right)$ are emitted from burning one gallon of gasoline. An electric vehicle produces no tailpipe emissions, but there are still upstream (GHG) emissions associated with an electric vehicle. These emissions originate from power plant electricity production and the emissions produced refining the materials used in an electric vehicle (EV) [5].

The experiments discussed within took place in Morgantown, WV. The electric provider for the region is MonPower. The Environmental Protection Agency's (EPA) "Power Profiler" tool [6], shows what percentage of power in the region is created using coal, nuclear, hydro, oil, or gas as an energy source. The national average for coal produced electricity is $38.7 \%$. The percentage of power produced using coal in the Morgantown region is sixty percent. The national average of $\mathrm{CO}_{2}$ produced from power production is 1,123 pounds per mega-watt hour, the amount of $\mathrm{CO}_{2}$ produced in Morgantown is 1,381 
pounds per mega-watt hour. Charging an eighty-five kilowatt hour battery pack emits 122 pounds of carbon dioxide [6].

Another online tool created by the EPA calculates emissions from electric vehicles based on upstream GHG. GHG are defined as nitrogen oxides $\left(\mathrm{NO}_{x}\right)$, sulfur dioxide $\left(\mathrm{SO}_{2}\right)$ and $\mathrm{CO}_{2}$. Upstream $\mathrm{GHG}$ are emissions that are produced during the manufacturing process of materials. The test vehicle, a 2013 Tesla Model S 85 (kilo-watt hours) kWh, produces 270 grams per mile of $\mathrm{CO}_{2}$ according to this calculator [7]. This emission rate is lower than the 430 grams per mile that an average new vehicle produces.

Argonne National Laboratory (ANL) created "The Greenhouse Gases, Regulated Emissions, and Energy use in Transportation Model" (GREET). This model accounts for all production emissions from each step of the production process [8]. Using the GREET model, one pound of nickel cobalt aluminum (NCA), which the Model S uses in its cathode, produces 10.7 pounds of $\mathrm{CO}_{2}$.

There are no associated tailpipe emissions with an electric vehicle, but there are vehicle emissions when the vehicle production process is considered.

\subsection{Comparison of Electric Vehicle to Luxury Sedans in Market}

Comparing the top three large luxury sedans in 2017, according to US World and News Report, the top three are the Tesla Model S, Genesis G90, and the Audi A7. All three vehicles are in the $\$ 68,000$ price range. All three vehicles were in their lowest trim and performance packages at the time of comparison. The Genesis $\mathrm{G} 90$ has a twin turbo 3.3L V6 internal combustion engine with a fuel economy rating of 17 city/ 24 Highway. The Audi A7 has a 3.0L supercharged V6 internal combustion engine with 21 City/ 29 Highway miles per gallon (MPG) fuel economy rating [9]. The Genesis costs $\$ 2,100.00$ to fuel it for the year. The Audi costs $\$ 1,750.00$ to fuel it for the year. The Tesla costs $\$ 650.00$ to power for the year. The Tesla emits no tailpipe greenhouse gas (GHG) emissions. The Genesis emits 454 grams of $\mathrm{CO}_{2}$ per mile for tailpipe emissions. The Audi emits 376 grams of $\mathrm{CO}_{2}$ equivalent per mile for tailpipe emissions. These calculations assume forty-five percent highway driving, fifty-five percent city driving, and 15,000 annual miles [7].

The Genesis G90 gets twenty MPG, consuming five gallons of gas per 100 miles. The Audi A7 achieves twenty-four MPG, consuming 4.2 gallons of gasoline per 100 miles. The Tesla gets ninety-nine MPGge, consuming thirty-four kWh of electrical energy per 100 miles. Using the conversion factor, that 
gasoline has $33.7 \mathrm{kWh}$ of energy per gallon, the Tesla consumes approximately one gallon of gasoline per 100 miles [10].

\subsection{Objective}

The objective of this paper is to see if the battery pack produces any emissions under various conditions. If emissions were emitted, was it possible for them to breach the vehicle cabin, exposing the passengers to harmful toxins. Secondary, it was desired to compare the manufacturer energy efficiency claims to on-road testing data, and dynamometer testing cycles.

\section{Review of Literature}

\section{Fuel Economy Ratings}

The government states that vehicles prior to model year 2007 calculated fuel economy from a city driving schedule, and a highway driving schedule [11]. The city test cycle represents urban driving where the vehicle is started with the engine cold and driven in stop-and-go traffic. The city test consists of a 505 second cold start phase, an 864 second transient phase, and a 505 second hot start phase. The test cell for the highway travel test must be between $68^{\circ} \mathrm{F}$ and $86^{\circ} \mathrm{F}$.

The highway test cycle represents a mixture of rural and interstate highway driving with a warmed-up engine. This test is to simulate longer trips in free-flowing traffic. The test cell temperatures must be within the same temperature range as the highway testing cycle.

The fuel economy rating for model year 2008 and later added three additional testing cycles to adjust the highway and city estimates to account for higher vehicle speeds, air-conditioning use, and colder temperatures.

The high-speed test is the US06 testing cycle, it represents highway driving at higher speeds and more aggressive acceleration and braking. The SC03 cycle is used to estimate fuel economy to account for air-conditioning usage under hot outside conditions. The test cell must be $95^{\circ} \mathrm{F}$ to account for sun loading, and the air-conditioning in the vehicle must be on. The cold temperature test cycle, tests the effects of colder outside temperature on cold-start stop-and-go traffic. The temperature in the testing cell for the cold temperature cycle must be $20^{\circ} \mathrm{F}$. 
The combined fuel economy rating us a weighted average of the city and highway test cycles [12]. The city test cycle is weighted by $55 \%$, and the highway test cycle is weighted by $45 \%$

\section{The Tesla Roadster Battery System}

The Tesla Roadster, Tesla's first battery electric vehicle uses 18650 style lithium-ion battery cells. The designers decided to use lithium-ion technology due to its commonality. It is used every day in laptops and cell phones. The battery pack of the Tesla roadster stored fifty-three kWh of energy, the equivalent energy of eight gallons of gasoline, Berdichevsky et al. [13] claim.

The 18650-style battery cell was chosen due to its size. It has a diameter of eighteen millimeters, and a length of sixty-five millimeters. If one of the cells were to fail in the battery pack overall performance would not be affected as if fewer, large lithium-ion batteries were used as a power source [13].

\section{Timeline on Battery Electric Vehicles}

The Public Broadcasting Service (PBS) released a documentary on the timeline of the electric vehicle [14]. In the 1830s Scottish inventor Robert Anderson created the first electric powered carriage which was powered by non-rechargeable cells. In 1859 a rechargeable lead-acid battery was created by a French physicist named Gaston Planté. By 1893 the first models of electric vehicles were debuted in Chicago. In 1900 twenty-eight percent of vehicles produced in America were powered by electricity. Henry Ford started to mass produce the Ford Model T in 1908. By the 1920s the electric vehicle was still a viable option, however; due to the increased range, horsepower, and the availability of gasoline, internal combustion engines became the chosen technology to power vehicles.

In 1966 Congress passed a bill that recommended electric vehicle technology to reduce air pollution. In the 1970s, with the Arab Oil Embargo in place there was a renewed interest in the electric vehicle market. Vanguard-Sebring debuted the CitiCar at the electric vehicle symposium in Washington, D.C., in 1974. The vehicle had a top speed of 30 miles per hour ( $\mathrm{mph}$ ) and a total range of 40 miles.

In 1990 California passed a Zero Emission Vehicle mandate stating that two percent of on road vehicles by 1998 had to produce zero tailpipe emissions. The number of vehicles was supposed increase to ten percent by 2008. In 1988 the C.E.O of General Motors approved the research and production of the 
vehicle EV1[6]. The EV1 was the first mass produced electric vehicle in recent times. It was powered by lead-acid batteries with a ninety-mile highway range and a seventy-mile city range per charge. The amount of charge that the EV1 contained was equivalent to 1.5 gallons of gas [15, p. 1]. However, by the end of 2004 General Motors stated that the EV1 would no longer be supported; reclaiming and crushing all EV1 cars. Tesla Motors (now Tesla) unveiled its Tesla Roadster in 2006, it was released in 2008. The Tesla Roadster was arguably the first BEV to compete with modern internal combustion engine vehicles, offering similar horsepower and range per charge [14].

Numerical Investigations of Vehicle Climate Control Strategies Impact on Plug-In Electrical Vehicle

\section{Battery Range}

Kandasamy et al. investigated how the efficiency of a BEV was reduced when the cabin cooling system was used [16]. When the ambient temperature is low, range decreases because of additional load on the battery due to the cabin climate control system. The range also decreases in the summer months when the temperature is higher due to the air-conditioning $(A C)$ of the cabin which runs off the high voltage (HV) system. Higher temperature climates place a higher load on the air-conditioning compressor causing the vehicle to consume more energy.

There are many factors affecting the consumption of the battery: such as operating conditions, ambient temperature, and cabin climate controls. Temperature also affects the life of the battery. Batteries need to operate within a certain temperature range for optimal performance. This requires that BEV have active cooling systems.

The lithium-ion battery pack discussed consisted of 114 modules for an ESS capacity of $36 \mathrm{kWh}$, with a nominal voltage of 480 volts (V). The ESS in the paper was passively cooled and heated using the ambient air, or the cabin air, depending. When the ambient air temperature increases by $5^{\circ}$ Celsius (C) the battery SOC reduces by $2.42 \%$. When the cabin target temperature is reduced by $2^{\circ} \mathrm{C}$ there is a $7.05 \%$ loss in ESS SOC [17]. 


\section{Energy Efficiency and Performance of Cabin Thermal Management in Electric Vehicles}

Energy used for cabin heating and cooling can drastically affect how long the car can travel. The energy management can quickly reduce the battery SOC. Energy efficiency of cabin thermal management can be improved using a heat pump utilizing the excess heat energy created from the powertrain components (i.e. electric motor). Key challenges to maintaining energy efficiency is cabin heating in cold temperatures, and battery cooling in hot temperatures. In cold temperatures when the battery and powertrain do not produce enough heat to maintain battery temperatures a supplemental resistive heater is used. A positive temperature coefficient (PTC) heater is usually used. The typical heater has a rating between four and six $\mathrm{kW}$ of power.

Heat pumps are a more efficient way to heat the cabin of the vehicle. Rather than converting electrical energy into heat energy the heat pump moves the heat from the hot powertrain system to the cabin [18].

\section{Electrical Vehicle Thermal Management System}

A patent invented by Peng Zhou for Tesla is a new thermal management system [19]. Early thermal management systems were overly complex, often using multiple heat management systems. Zhou's patent uses multiple heat exchanger circuits using the same medium. The circuits are all connected to each other, allowing the high temperature circuit to flow to the low temperature circuit, or the low temperature circuit to cool the high temperature circuit.

The invention cools a heat exchanger with a refrigerant. This first loop flows through the vehicles ESS. The second loop flows through the heat exchanger as well as the vehicles heating, ventilation and air conditioning (HVAC) system. The third loop circulates through the vehicles drive motor, and exchanges with the second loop. The method of using the same refrigerant and heat exchanger throughout several coolant loops eliminates the need to place heavy loads on the ESS, previously used for heating and cooling. 


\section{Panasonic Delivers Over 100 Million Lithium-Ion Battery Cells for Tesla's Model S EV}

The press release [20] states a partnership between Tesla and Panasonic. Panasonic announced that it would produce the lithium-ion battery cells for the Model S. The two started their partnership when Tesla first debuted their Roadster model. The relationship was continued throughout the production of the Model S. The 18650-style battery cell used in the Model S was designed for energy density and performance. They were specially manufactured for use in an electric vehicle [20].

Online Capacity Estimation for Automotive Lithium-Ion Cells Incorporating Temperature-Variation and $\underline{\text { Cell-Aging }}$

Advanced algorithms are needed to estimate battery state of charge and capacity. The capacity of a battery is a function of, battery age, temperature, and discharge current. Where the battery cell age is referred to as state of health $(\mathrm{SoH})$.

$$
C(T, S o H, I)=\int_{U \min }^{U \max } I(t) d t
$$

Equation 1 Capacity of a Battery

Where:

$\mathrm{T}$ is the temperature

$\mathrm{SoH}$ is the state of health

$\mathrm{I}$ is the current

$C$ is the charge

$U_{\min }$ and $U_{\max }$ are the minimum and maximum voltages, respectfully,

Most of the SOC estimation methods rely on open circuit voltage (OCV). OCV is a direct function of the SOC of the battery pack. Cell capacity is measured by counting the amount of charge that left the battery during a discharge period. A waiting period of several hours must take place before an accurate measurement can take place. Immediately after charging or discharging, there are transient effects in the battery pack that can give unreliable OCV data until they settle. In a laboratory setting the cell capacity is 
measured by extracting all the charge from the battery. In practice, a battery should never be discharged to zero percent SOC [21].

\section{$\underline{\mathrm{DC} \text { arc fault in lithium-ion batteries }}$}

The current interrupt device is a safety feature built into 18650 style batteries. It breaks like a fuse when gas pressure gets too high internally—because of overcharging. Over pressure typically occurs when internal battery pressure reaches greater than ten bar.

Under high voltage circumstances an arc can form when the CID opens in an 18650-battery cell. This can cause a battery cell failure. Other primary causes for battery cell failure are temperature rise, thermal runaway, over pressure, overcharge, over discharge, and electric arc internal and external short circuits. Over pressure can occur while recharging. When electrical energy is turned into chemical energy. Gases and heat are released as a result.

This is especially dangerous in an ESS with thousands of cells in the same pack. If one cell ignites it can start a chain reaction leading to thermal runaway. A thermal runaway is when one battery cell in an ESS bursts due to overpressure, and ignites. This causes the neighboring cells to overpressure, burst, and ignite as well. This trend will continue until the entire pack is consumed [22].

\section{Assessment of Performance of Lithium Iron Phosphate Oxide, Nickel Manganese Cobalt Oxide and}

\section{Nickel Cobalt Aluminum Oxide Based cells for Using in Plug-in Battery Electric Vehicle Applications}

Lithium ion battery types are characterized by the composition of the cathode. Various lithium ion battery types, including lithium iron phosphate oxide (LFP), lithium manganese cobalt oxide (NMC) and (NCA), batteries were compared for energy density, and performance at different temperatures.

A baseline energy density for the three battery compositions was taken at a temperature range of $40^{\circ} \mathrm{C}$ to $0^{\circ} \mathrm{C}$. The results were then compared to performance at $-18^{\circ} \mathrm{C}$. The NMC lost sixty percent of its energy density, NCA composition lost forty percent energy density, and the LFP lost twenty percent. The paper goes on to explain that while NCA batteries performed well compared to the other two chemistries at a temperature of $-18^{\circ} \mathrm{C}$ a heating system would be required to maintain the performance of the batteries [23]. 
Characterizing Thermal Runaway of Lithium-ion Cells in a Battery System Using Finite Element Analysis Approach

Yeow et al. tested a mini battery pack using three pouch style seventy amp hour (Ah) NMC cells cooled on a liquid cooling plate [24]. It was tested to see how a thermal runaway occurs when a battery pack is overheated. At $80^{\circ} \mathrm{C}$, the lithium salt in the electrolyte starts to decompose. At $110^{\circ} \mathrm{C}$ the anode starts to decompose and react with the lithium electrolyte. At $130^{\circ} \mathrm{C}$ the binders start to melt. At $150^{\circ} \mathrm{C}$ the separator between the anode and the cathode begins to melt. At temperatures above $250^{\circ} \mathrm{C}$ the lithium electrolyte dries out.

There are five lithium ion chemistries mentioned by the author, lithium cobalt oxide (LCO), lithium manganese oxide (LMO), (NMC), (NCA), and lastly (LFP). The author ranks these five in order of decreasing specific heat release during a thermal runaway event. In order of decreasing heat release: LCO, NCA, NMC, LMO, LFP.

Thermal runaway can be triggered by electrical, mechanical or thermal abuses. The main cause of thermal runaway is the self-heating that occurs due to chemical reactions taking place inside the battery cell [24].

\section{Energy Consumption}

\subsection{Document SAE J1634}

Society of Automotive Engineers International (SAE) document, SAE J1634 [25], refers to the proper procedures to test the energy consumption of a BEV. The direct current (DC) energy (Edc) is equal to the voltage multiplied by the current, this product yields watts. Dividing watts by 3600 and the frequency of data collected gives an answer in watt-hours (Wh). This is the net energy that the BEV consumed during testing. The goal is to calculate the gasoline equivalent fuel economy (MPGge) for a 2013 Tesla Model S P85. 


$$
E d c=\frac{1}{3600 * f} * \sum_{j=0}^{n} V_{j} * i_{j}
$$

\section{Equation 2 DC Energy Calculation}

Where:

$\mathrm{V}_{\mathrm{j}}$ represents the Battery DC bus voltage.

$\mathrm{i}_{\mathrm{j}}$ represents the battery current

The summation of the product of $V_{j}$ and $i_{j}$ is the wattage.

$f$ is the frequency of the measurements

$\mathrm{n}$ is the number of samples

The document [25, p. 163], states that the current clamp must be placed in a way that current both entering and exiting the battery pack can be recorded. The high voltage was recorded using a high voltage differential probe, measured off of the busbar in the main contactor pack, Figure 2.

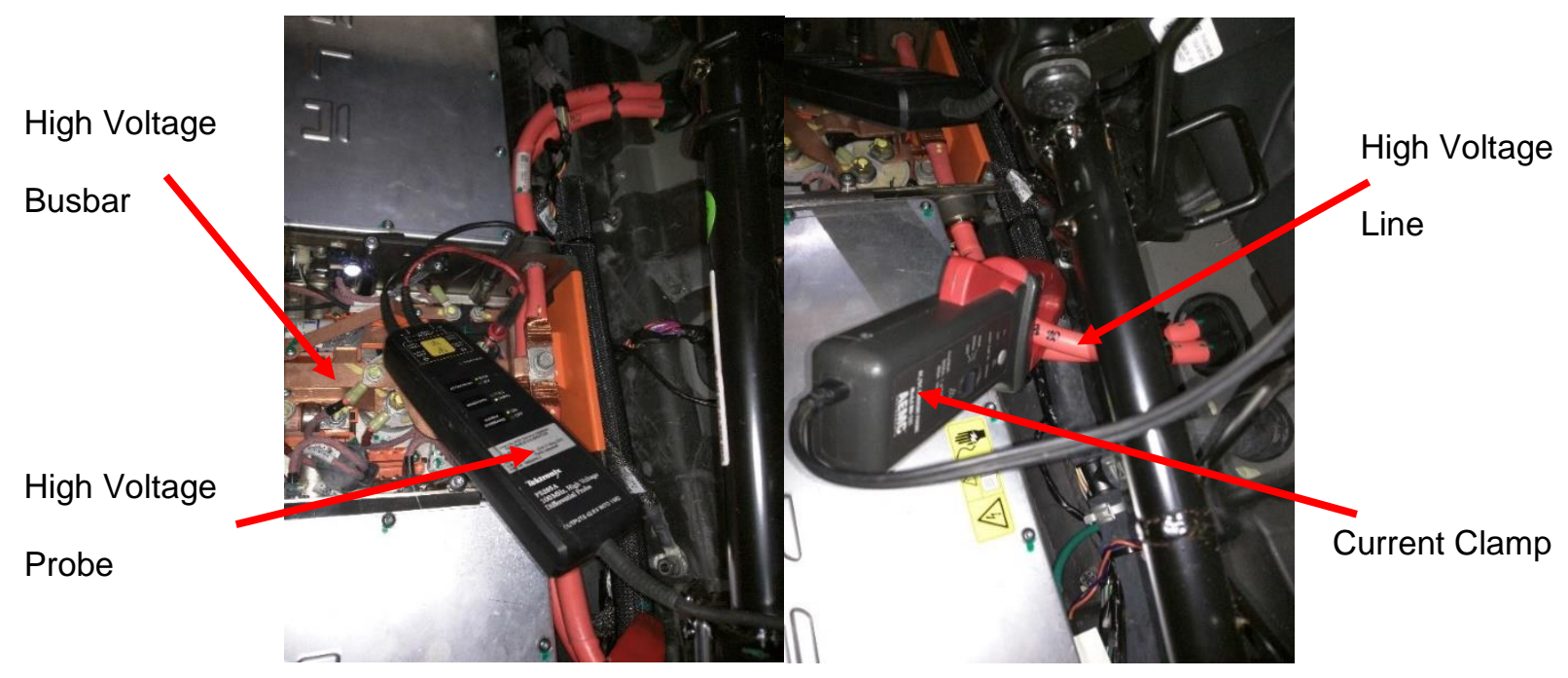

Figure 2 Left: The Differential Probe. Right: The Current Clamp

\subsection{On-Road Testing Experimental Setup}

The on-road testing required three main pieces of hardware to capture vehicle data. An AEMC Instruments, Figure 3, current clamp was used to measure the current consumed by the electric motor, as well as all current consumed by the electric subsystems. The current clamp has an accuracy of $\pm 2.5 \%$. A 
Tektronix high voltage differential probe, seen in Figure 4, was used to measure the battery voltage at the battery pack's main contactors busbar. The high voltage differential probe has an accuracy of $\pm 2 \%$. A GlobalSat BU-353 global positioning system (GPS) was used to track vehicle altitude and vehicle speed, Figure 5.

The access points for both the high voltage and the current conductors are located underneath the rear seat of the vehicle. After the rear seat was removed the current conductor could be clamped. The main contactors for the vehicle were located the middle of the rear seating area. Originally the main contactors were covered with a protective metal plate. A custom plate was made from acrylic to replace the stock cover. Two holes were drilled for voltage probe connectors in the acrylic plate. This ensured that the main contactor pack did not expose any researcher to high voltage while the differential probe was installed or removed.

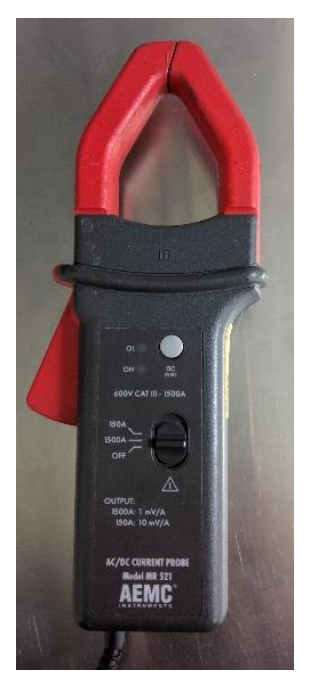

Figure 3 AEMC Instruments Model MR 521 AC/DC Current Probe 


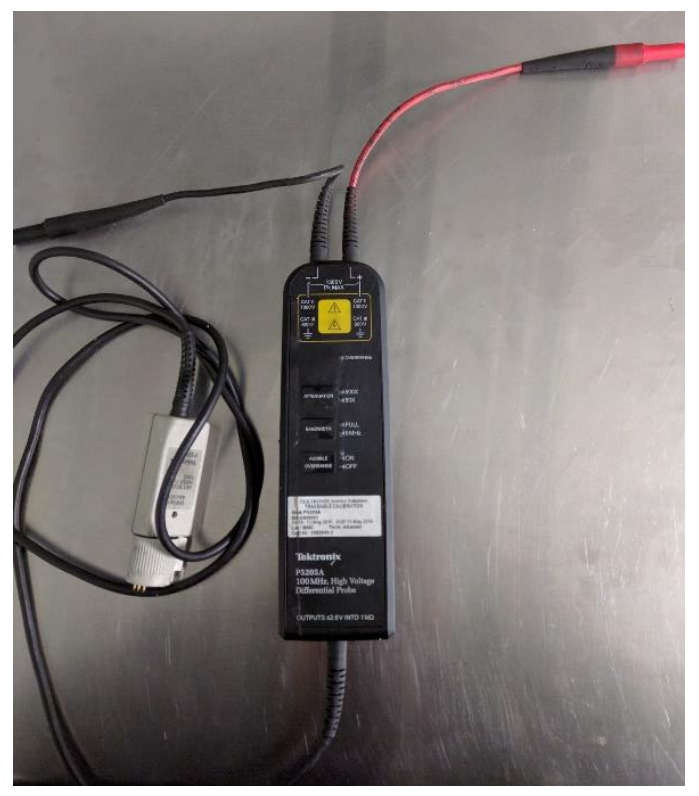

Figure 4 Tektronix P5205A 100MHz, High Voltage Differential Probe

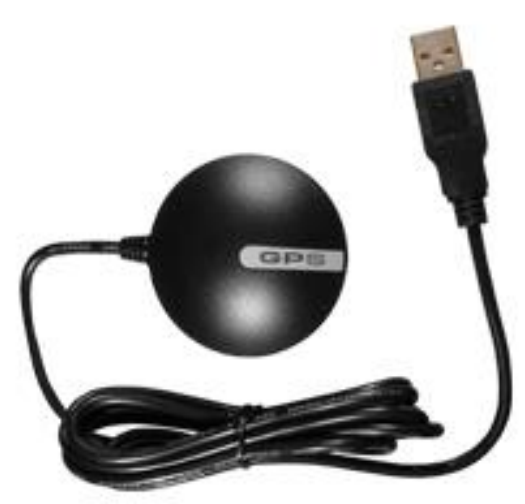

Figure 5 GlobalSat BU-353 GPS Unit

The last piece of hardware used for on road energy consumption was a LabJack UE9. The LabJack UE9 is an ethernet multifunction data acquisition (DAQ) with fourteen analog inputs [26, p. 9]. The LabJack senses voltage changes in the testing equipment and transmits the data to DAQ software. A DAQ software developed by Zachary Luzader called Scimitar was used for this research.

The differential probe and the LabJack needed to be powered by $120 \mathrm{~V}$, sixty hertz $(\mathrm{Hz})$ power. A 1500-watt (W) voltage converter was used to power these devices from a twelve volt plug in the vehicle's cabin. The converter also allowed the laptop to be charged during longer trips. The current clamp was 
powered by a $9 \mathrm{~V}$ battery, its output was zero to five $\mathrm{V}$ and was directly connected to the LabJack. The GPS directly interfaced with the laptop with Scimitar through a universal serial bus connecter (USB) on the DAQ computer.

The twelve-volt power source for the voltage converter was on a five amp (A) fused circuit. Based on the current consumption of the LabJack and laptop charger the fuse would not blow. The results of the test were not influenced by the current draw of the DAQ systems. The max current draw for a charging laptop was 3.3A. The high voltage probe drew $0.3 \mathrm{~A}$ and the LabJack drew $0.2 \mathrm{~A}$. The DAQ systems ran off of the twelve-volt battery. The twelve-volt system is recharged via the high voltage battery so the low voltage and the high voltage systems are connected. However, the extra current draw of $3.8 \mathrm{~A}$ on the low voltage system is negligible when compared to the current draw on the high voltage battery, which is an order of magnitude higher.

From the driver's seat, the researcher could monitor all systems to ensure that they were providing data with reasonable values.

\subsubsection{Coopers Rock}

The BEV was taken from the Vehicle and Engine Testing Laboratory (VETL), located off of Greenbag road, in Morgantown, West Virginia, to the Coopers Rock State Forest overlook. This was a preliminary test to ensure that the onboard recording systems were properly operating and recording. Figure 6, shows the eighteen-mile route taken. 


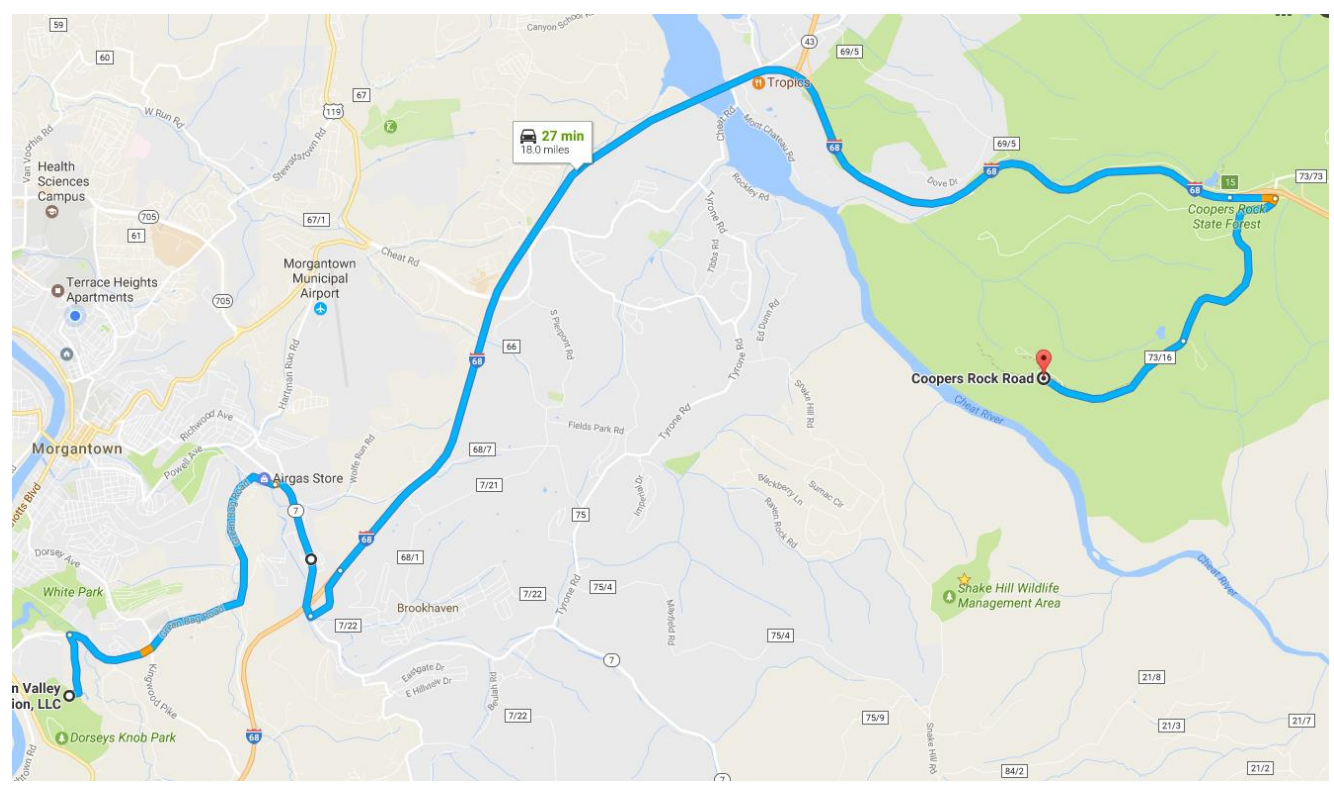

Figure 6 The Route Taken to Coopers Rock

The average temperature for the day was $55^{\circ} \mathrm{F}$ with spotty rain showers. The trip was taken to acquire highway data via I-68E, as well as lower speeds of $15-30 \mathrm{mph}$, posted in the state forest. It can be seen in Figure 7 that the current periodically spikes to over 1000A. This was when the driver passed vehicles on I-68, the highway portion of the trip. Around 3000 seconds in the graph below, it shows that there are no more current spikes. This is when the vehicle entered Coopers Rock State Forest, and the posted speed limit was lowered to $15 \mathrm{mph}$.

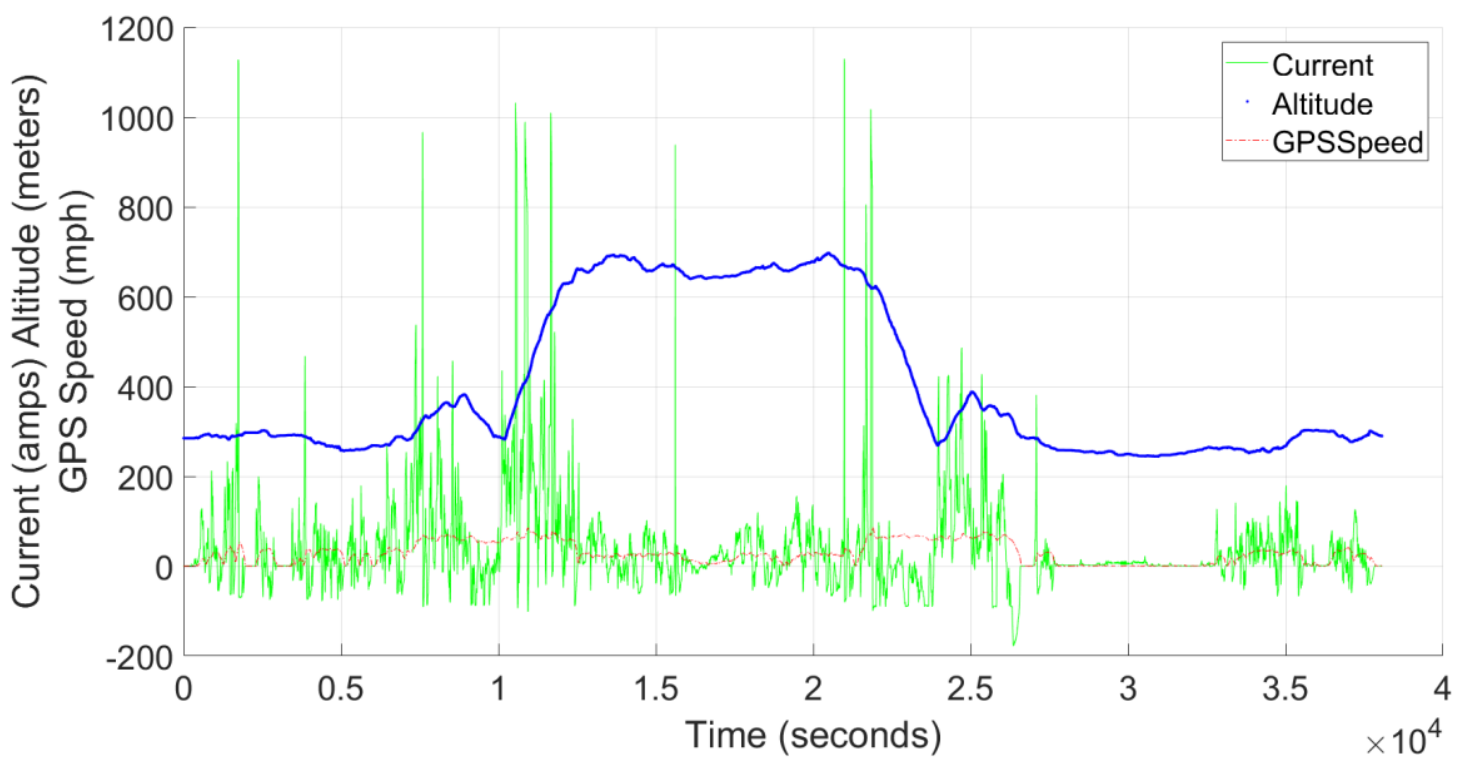

Figure 7 Current, Elevation, and Vehicle Speed 
Based on Morgantown Residential Electric Service of $\$ 0.09448$ per kilowatt hour $(\mathrm{kWh})$ of energy seen in Figure 8 , the round trip total cost was $\$ 1.31$, and $13.9 \mathrm{kWh}$ of energy were consumed during the trip. Eighty-four MPGge was recorded for this trip.

\section{RESIDENTIAL SERVICE RATE SCHEDULE "A"}

AVAILABLE for single phase residential use through one meter.

MONTHLY RATE (For a single residence)

Customer Charge $-\$ 5.00$ per month

Energy Charge

All kilowatt-hours.

$\$ 0.09448$ per kilowatt-hour

Figure 8 Residential Service Rate for MonPower Morgantown,

WV

The consumed energy was calculated from the data recorded during the trip. The recorded GPS speed was numerically integrated to calculate the total miles traveled by the BEV. From the current and the voltage data, the power consumed was calculated. Integrating power (watts) with respect to time, gives the energy consumed (watt-hours). The energy-consumption can then be used to calculate the cost of the trip.

The BEV recorded on-board that the average specific energy consumption of the round trip was $381 \mathrm{Wh} / \mathrm{mi}$. Data that was collected with the current clamp, voltage probe, and GPS, showed that the realtime road test data had an average consumption of $401.98 \mathrm{Wh} / \mathrm{mi}$. The ambient temperature for the day was $37^{\circ} \mathrm{F}$, with some rain showers. The climate control of the vehicle was set to $73^{\circ} \mathrm{F}$ with the windshield defroster and the windshield wipers on.

\subsubsection{Morgantown Route}

The Morgantown Route is an on-road test cycle designed by Center for Alternative Fuels, Engines and Emissions (CAFEE) researchers to simulate a mix of urban and highway driving conditions. The route is seen below in Figure 9. 


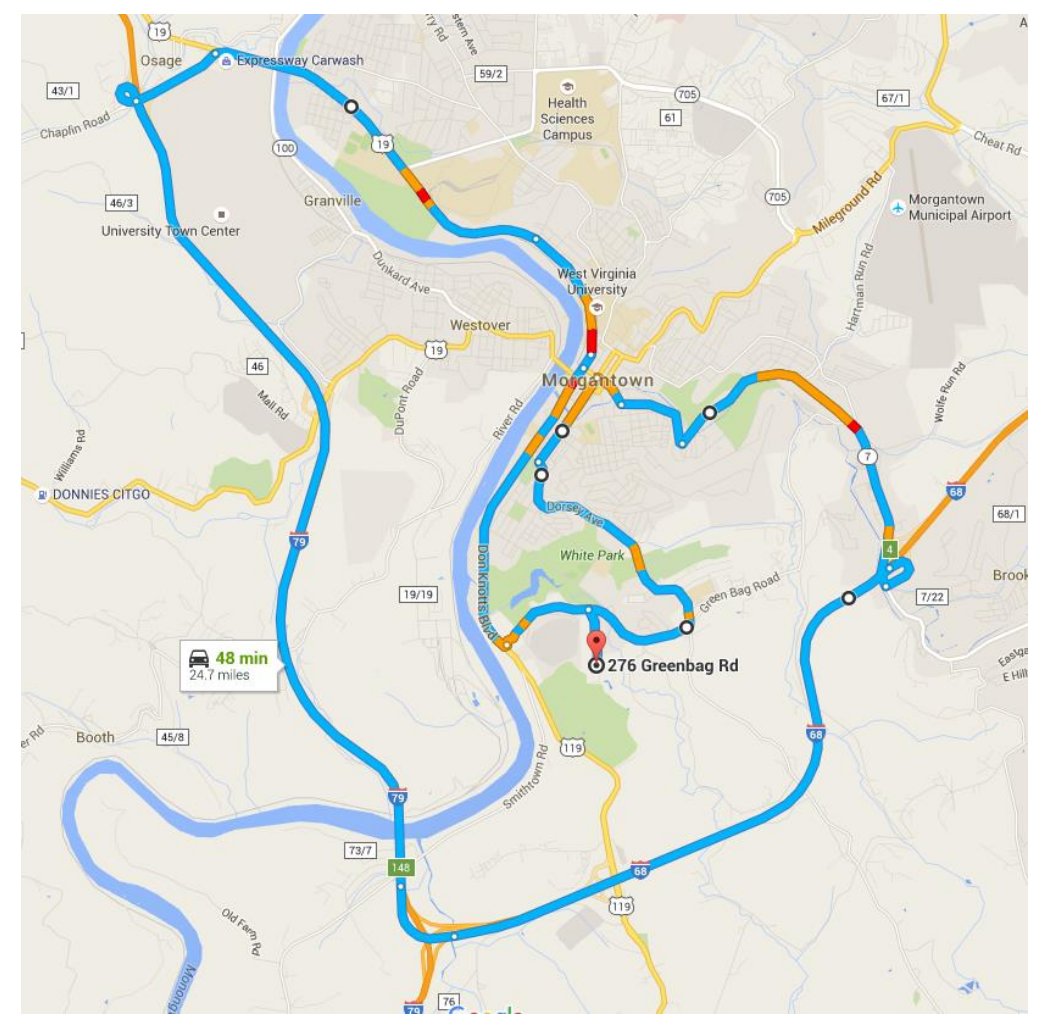

Figure 9 The Morgantown Route Displayed on a Map

It is a 25-mile-long route that incorporates highway travel via I-79, as well as two lane road ways throughout more congested areas of Morgantown, WV (i.e. Sabraton, and High Street). This route simulates traffic conditions and styles of driving that a typical Morgantown denizen would see daily. Figure 10 shows the data collected while driving the Morgantown Route. 


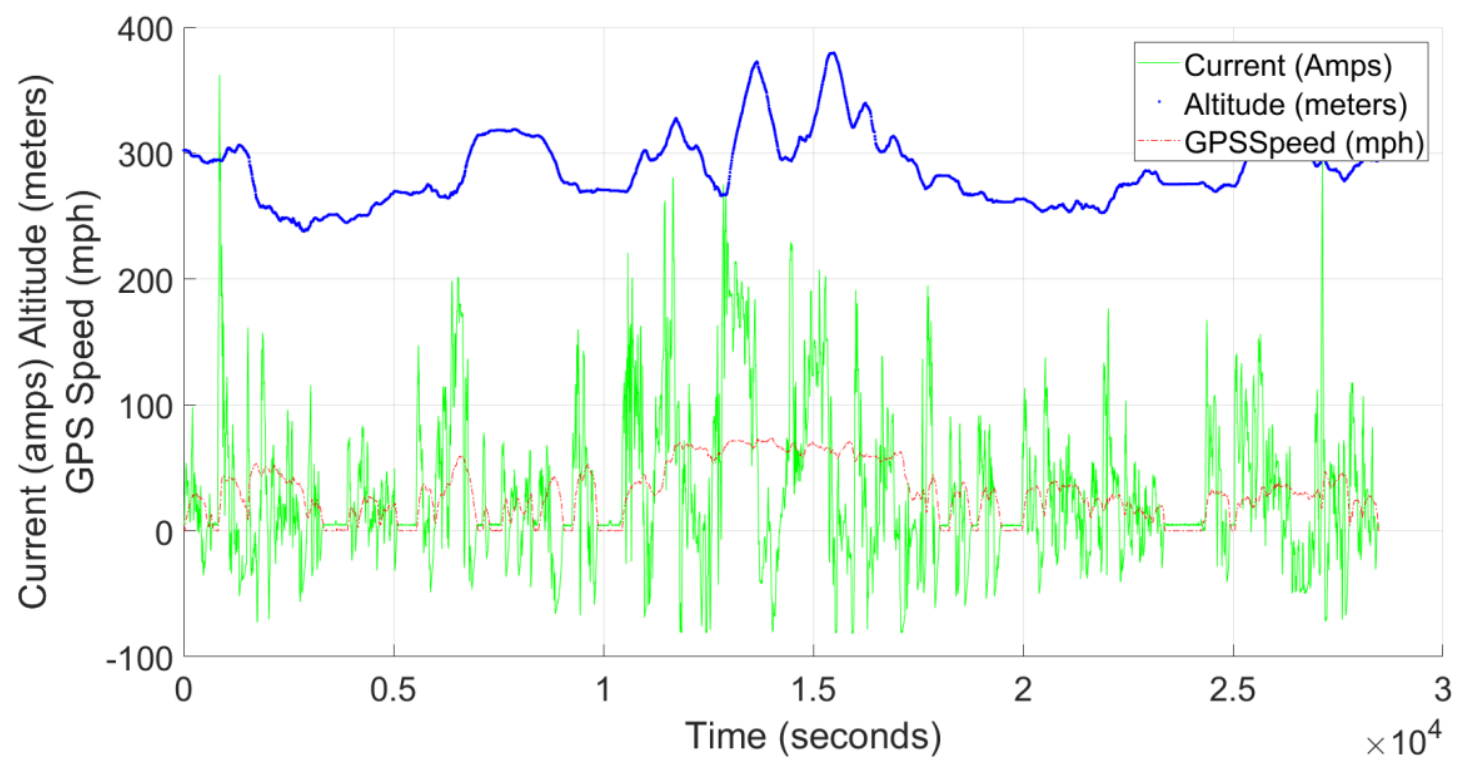

Figure 10 Current, Altitude, and Vehicle Speed for the Morgantown Route

At the beginning of the Morgantown route the Tesla displayed 178mi of range. At the end of the test the Tesla displayed that the trip was 25.1 miles long with 150 miles of range left. The average energy consumption as recorded by the Tesla system showed $312 \mathrm{Wh} / \mathrm{mi}$. Experimental data recorded using the current clamp and high voltage differential probe show a power consumption of $355 \mathrm{Wh} / \mathrm{mi}$. The average MPGge calculated using document SAE J1634 [25] was 95 MPGge, and the total trip cost was $\$ 0.82$ using the local schedule rate for residential electricity. The equivalent fuel consumption, using a lower heating value (LHV) for gasoline of $33705 \mathrm{Wh} / \mathrm{gal}$, was 0.26 gallons. The ambient temperature for the trip was $65^{\circ} \mathrm{F}$ and mostly cloudy. The total elevation change of the trip, from the lowest point to the highest point was $141 \mathrm{~m}$. The ambient temperature for the day was $68^{\circ} \mathrm{F}$ with some clouds. The HVAC system was not used during the trip.

\subsubsection{Bruceton Mills Route}

The route to Bruceton Mills is 50 miles long and is used to collect local highway data. It starts out at VETL, in Morgantown, WV, and travels by highway until the Bruceton mills exit via I-68E. I-68 maintains highway speeds of $70 \mathrm{mph}$, with an increasing elevation of approximately 400 meters. Figure 11, shows a map of the Bruceton Mills route. 


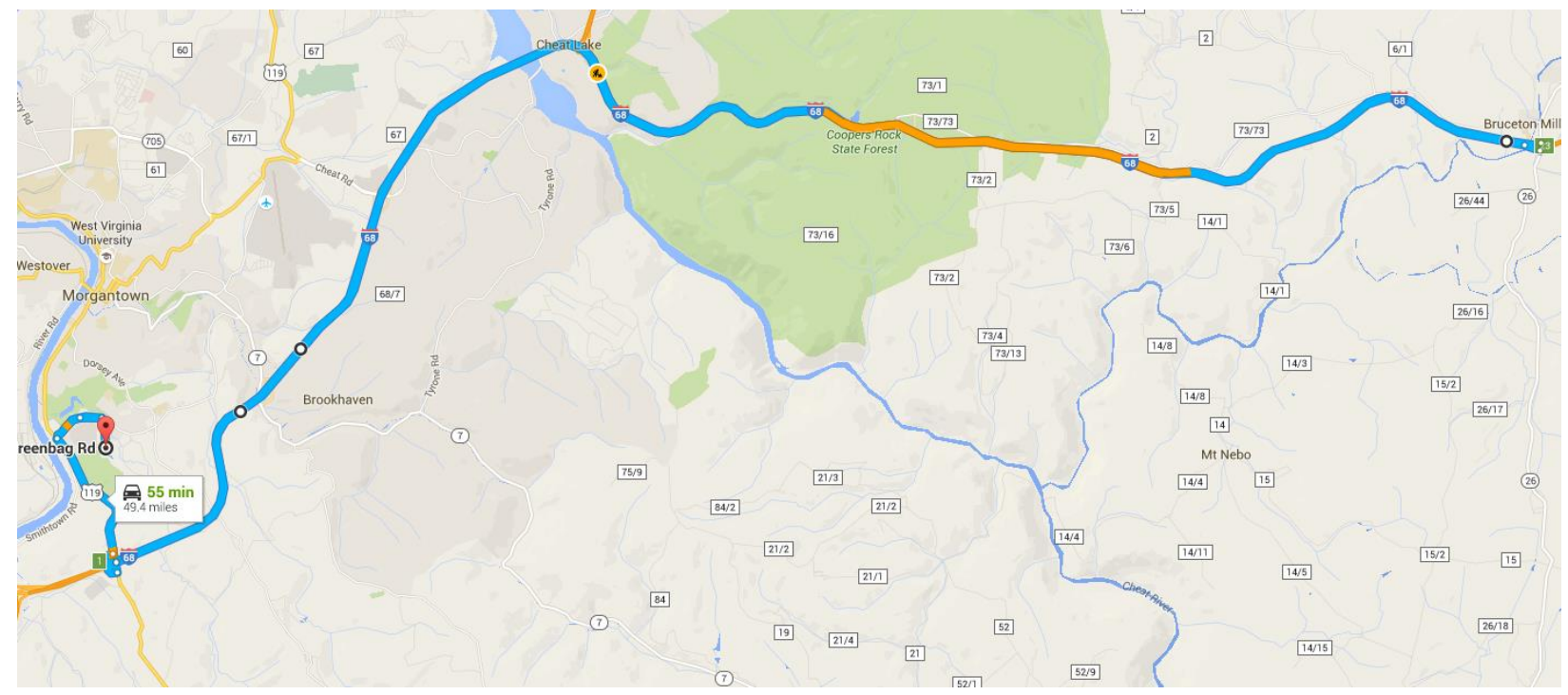

Figure 11 Bruceton Mills Route Shown on a Map

The data for the Bruceton Mills highway was broken into two different trips. One trip was outgoing from the Vehicle and Engines Testing Laboratory (VETL) to Bruceton Mills, WV, the other trip was the return trip. The results are displayed in the Table 1 below.

Table 1 Details for Each Leg of the Bruceton Mills Route

\begin{tabular}{|l|c|c|}
\hline & VETL to Bruceton Mills & Bruceton Mills to VETL \\
\hline Average MPGge & 83.02 & 104 \\
\hline Cost $(\$)$ & 0.95 & 0.75 \\
\hline Energy per Mile $(\mathrm{Wh} / \mathrm{mi})$ & 406 & 324 \\
\hline Altitude Change $(\mathrm{m})$ & +394 & -396 \\
\hline
\end{tabular}

The two sets of data represent the same route driven, however; there are key differences between the two. The outgoing trip to Bruceton mills had an elevation climb of approximately 395 meters. Figure 12 shows the graphical representation of the trip from VETL to Bruceton Mills. Due to the increasing elevation, the vehicle was unable to utilize regenerative braking, because of this it consumed $82 \mathrm{Wh} / \mathrm{mi}$ more on the outgoing trip. Around 8000 seconds, when the elevation climb began, the BEV consumed between 200 and $150 \mathrm{~A}$ for 2000 seconds. 


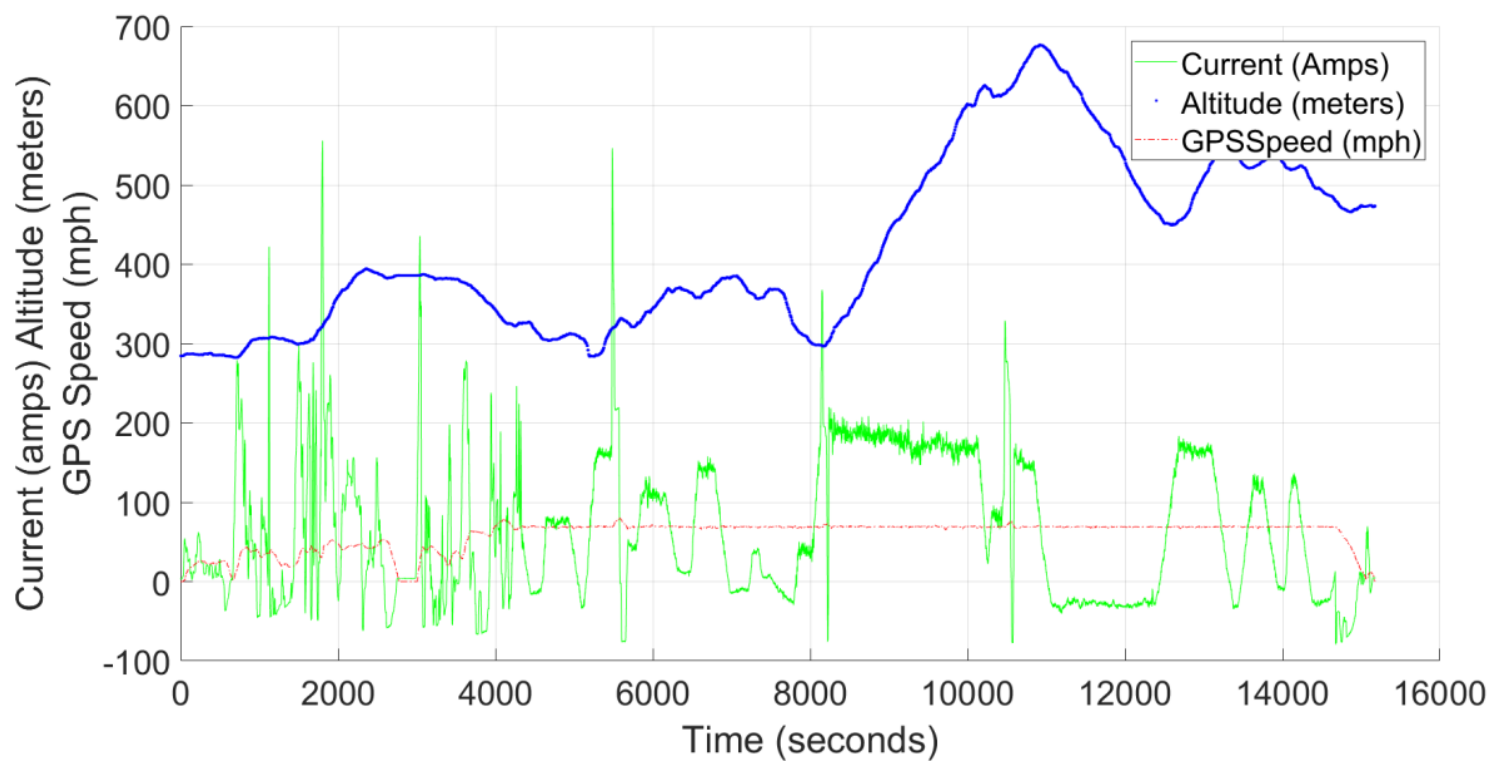

Figure 12 Bruceton Mills Route; from VETL to Bruceton Mills

On the return trip, Figure 13, the vehicle could utilize regenerative braking during the long downhill sections of the trip to recharge the batteries, resulting in higher MPGge.

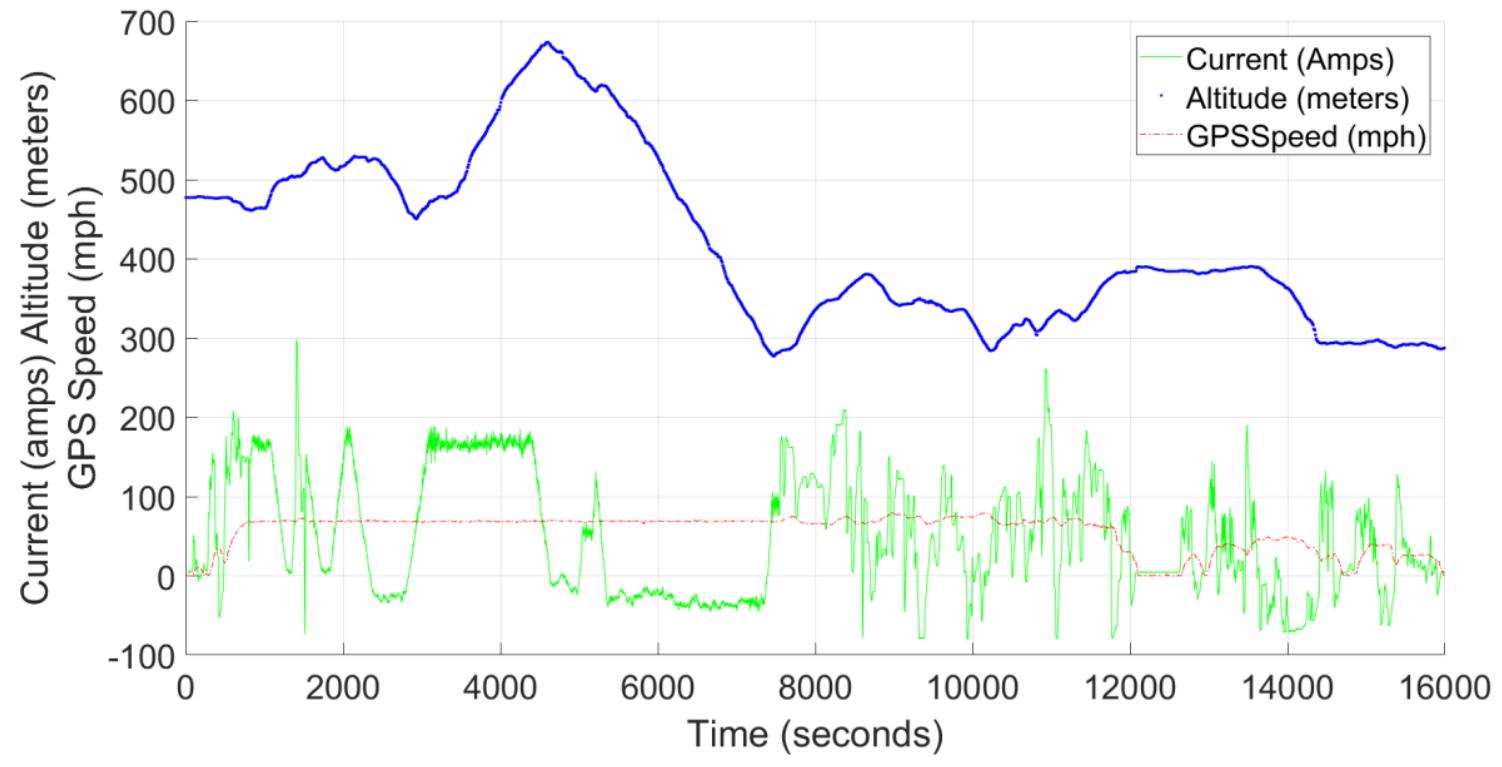

Figure 13 Bruceton Mills Route; from Bruceton Mills to VETL.

The decreasing elevation occurring in the figure directly above, between 6000 and 8000 seconds shows that the current is negative. This shows that the BEV was using regenerative braking to produce 
energy to recharge the ESS. The ambient air temperature for the day was $68^{\circ} \mathrm{F}$ with some clouds. The HVAC system was not used.

\subsection{Comparison of Bruceton Mills Route and Morgantown Route}

It can be seen from the data above that the Bruceton mills route, both to and from VETL, had higher MPGge than the Morgantown route. This is because the Bruceton Mills route is highway speeds. There is no starting and stopping typically associated with city driving. The vehicle does not have as many positive acceleration points. The highway travel is a more constant consumption as opposed to the current spikes commonly seen in the Morgantown route. Another difference is that on the return trip of the Bruceton Mills route, (Bruceton Mills to VETL) the altitude drops by 396 meters. This creates opportunity for regenerative braking. On the highway, cruise control was set to $70 \mathrm{mph}$. This allowed the BEV control system to take control, using regenerative braking as needed. In the Morgantown route, the driver relied more on the friction brakes to maintain speeds. Regenerative braking is a function of deceleration, as well as limits of the inverter, and the battery SOC. The amount of regenerative braking is controlled by the vehicle controls system. The driver has no direct influence on how much regenerative braking is used. The driver inputs a braking demand, the vehicle control system decides how much of the braking comes from the frictional brakes, and how much comes from regenerative braking.

The Genesis G90 achieves a fuel economy of twenty combined MPG and the Audi A7 achieves a fuel economy of twenty-four combined MPG. If these two ICE powered vehicles were to drive the Morgantown and Bruceton Mills routes they may get lower than rated fuel economy, due to the altitude change and the fact that energy cannot be recovered during decent in these vehicles. The default cost for premium gasoline in the fuel economy comparison EPA website [10] was $\$ 2.80$ per gallon. Using this fuel cost, and the fuel economy ratings of the above ICE powered vehicles, a trip cost can be calculated for the Audi A7 and the Genesis G90. The Audi A7 costs $\$ 2.92$ to run the Morgantown route and $\$ 5.82$ to run the Bruceton Mills route. The Genesis G90 costs $\$ 3.50$ to run the Morgantown route and $\$ 7.00$ to run the Bruceton Mills route. 


\subsection{Dynamometer Testing Experimental Setup}

After testing the vehicle on-road, the electric vehicle was installed on a four-wheel roller, eddy current dyno. The tests took place over a span of three evenings. Each test was repeated three times once each night, to help account for variability in the vehicle or measurement equipment. During the dyno tests the battery voltage was recorded, as well as vehicle speed and the current entering and exiting the battery. This approach captures the current during periods of positive acceleration as well as during regenerative braking. The data was recorded using the in-house DAQ software called Scimitar. The hardware used to record the energy consumption consisted of the previously described current clamp, high voltage differential probe, and LabJack UE9. The same placement for the components was used during the on-road testing.

\subsection{Dynamometer Testing}

\subsubsection{First Night January 25, 2017}

Document SAE J1634 [25] was referenced for the formulas used in calculating the MPGge of the electric vehicle. The current clamp was placed on the positive high current conductor connected to the battery to measure current entering and exiting the battery. Using the formulas in SAE J1634 the fuel economy of the battery electric vehicle was calculated. The residential rate schedule for Morgantown, West Virginia was incorporated to determine the cost of each test cycle using grid energy.

The four tests selected were FTP75, US06, SC03, and HWFET. There were two drivers that drove the vehicle on the dynamometer. Driver 1 drove on the first, and third night of testing. Driver 2 drove on the second night of testing. The HVAC was not used during any of the test cycles.

The first evening of testing driver 1 drove the test vehicle for the four testing cycles. Due to an error in the DAQ system, the ambient test cell temperature was not recorded. The SOC of the vehicle was not recorded, however; the first night of testing the SOC was less than the second night SOC, but higher than the third night SOC. 
Table 2 MPGge and Trip Cost for the Four Federal Test

Procedures

\begin{tabular}{|c|c|c|c|}
\hline FTP75 MPGge & US06 MPGge & SC03 MPGge & HWFET MPGge \\
\hline 127.25 & 95.60 & 121.88 & 134.23 \\
\hline \multicolumn{4}{|c|}{ Average MPGge } \\
\hline \multicolumn{3}{|c|}{119.74} \\
\hline FTP75 Cost & US06 Cost & SC03 Cost & HWFET Cost \\
\hline$\$ 0.28$ & $\$ 0.27$ & $\$ 0.09$ & $\$ 0.24$ \\
\hline
\end{tabular}

\subsubsection{Second Night January 26, 2017}

The second evening of testing, driver 2 drove the tests on the vehicle. It can be seen in the below table that the fuel economy decreased for all four test cycles as compared to the first night. The ambient temperature in the test cell ranged between $67^{\circ} \mathrm{F}$ and $68.5^{\circ} \mathrm{F}$. The SOC on the second night of testing was the highest of the three nights of testing.

Table 3 MPGge and Trip Cost for the Four Federal Test

Procedures

\begin{tabular}{|c|c|c|c|}
\hline FTP75 MPGge & US06 MPGge & SC03 MPGge & HWFET MPGge \\
\hline 111.01 & 91.14 & 106.57 & 123.99 \\
\hline \multicolumn{4}{|c|}{ Average MPGge } \\
108.17 \\
\hline FTP75 Cost & US06 Cost & SC03 Cost & HWFET Cost \\
\hline$\$ 0.32$ & $\$ 0.28$ & $\$ 0.11$ & $\$ 0.26$ \\
\hline
\end{tabular}

\subsubsection{Third Night January 27, 2017}

The third night of testing, driver 1 drove the tests. The ambient temperature in the test cell ranged between $66^{\circ} \mathrm{F}$ and $67.5^{\circ} \mathrm{F}$. The third night of testing had the lowest SOC of the three nights of testing. 
Table 4 MPGge and Trip Cost for the Four Federal Test

Procedures

\begin{tabular}{|c|c|c|c|}
\hline FTP75 MPGge & US06 MPGge & SC03 MPGge & HWFET MPGge \\
\hline 108.8 & 86.49 & 110.64 & 119.98 \\
\hline \multicolumn{4}{|c|}{ Average MPGge } \\
106.29 \\
\hline FTP75 Cost & US06 Cost & SC03 Cost & HWFET Cost \\
\hline \$0.33 & $\$ 0.30$ & $\$ 0.10$ & $\$ 0.27$ \\
\hline
\end{tabular}

The code used to analyze the data collected during testing is found in Appendix B.

\subsection{Graphical Comparison}

As previously stated, the BEV was exercised over four federal test procedures three nights in a row to account for variability in testing. Figure 14 shows the vehicle speed profile for each of the three tests. The three lines on each of the graphs correlate to the three evenings the vehicle was tested. The three speed traces closely resemble each other however the driver on the second night of testing did not follow the speed trace as well and thus resulted in more current consumption.

The vehicle did not start with the same SOC at the beginning of each night of testing. This was an oversight on the researcher's part. If the SOC was the same at the beginning of each of the tests a better comparison could be made. 

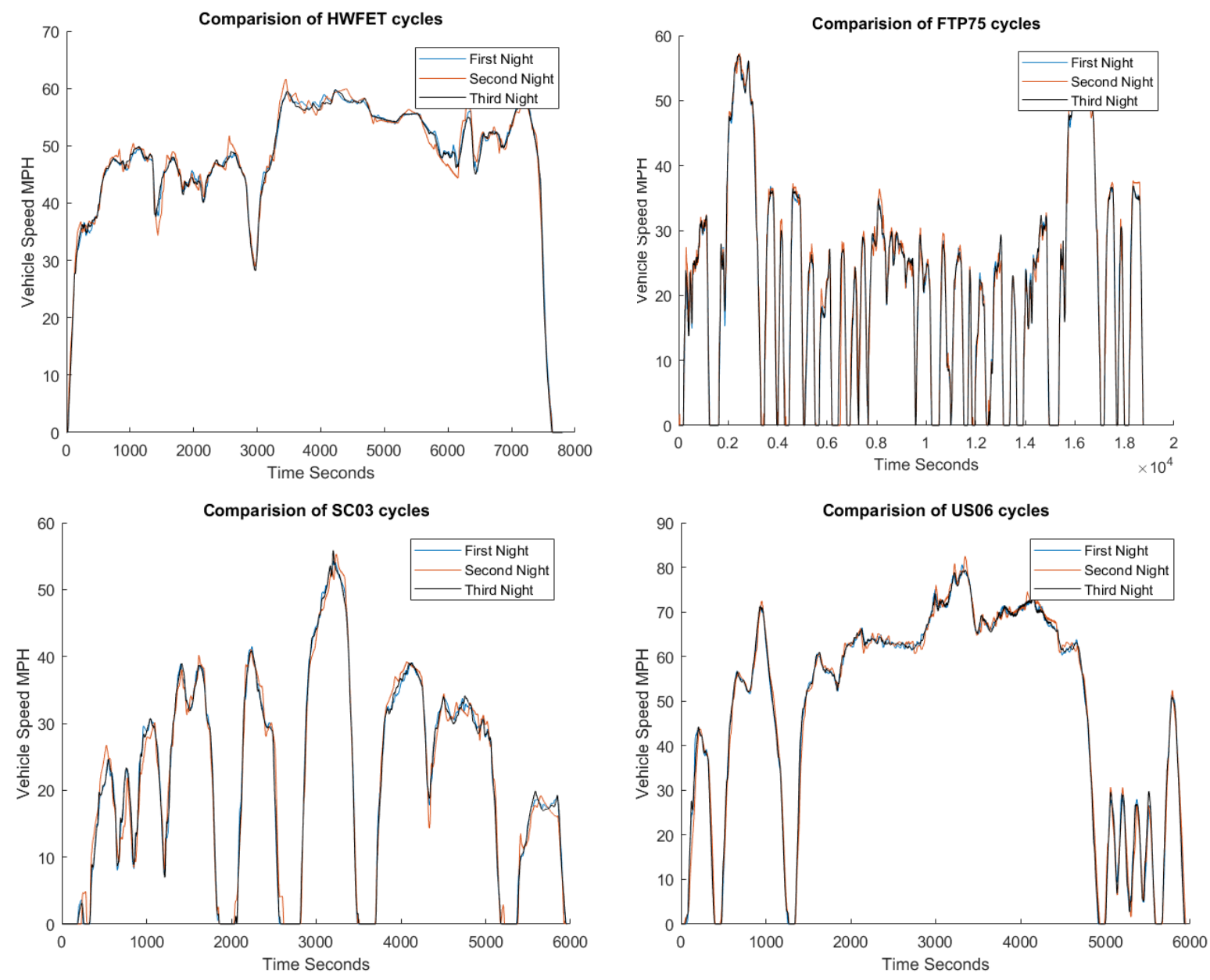

Figure 14 Vehicle Speed Data for Three Nights of Testing

Figure 15 shows the comparison for the current data collected over each night of testing. The second night shows higher current spikes than the other two nights. This means that the driver the second evening accelerated harder than the driver of the first and third night. 

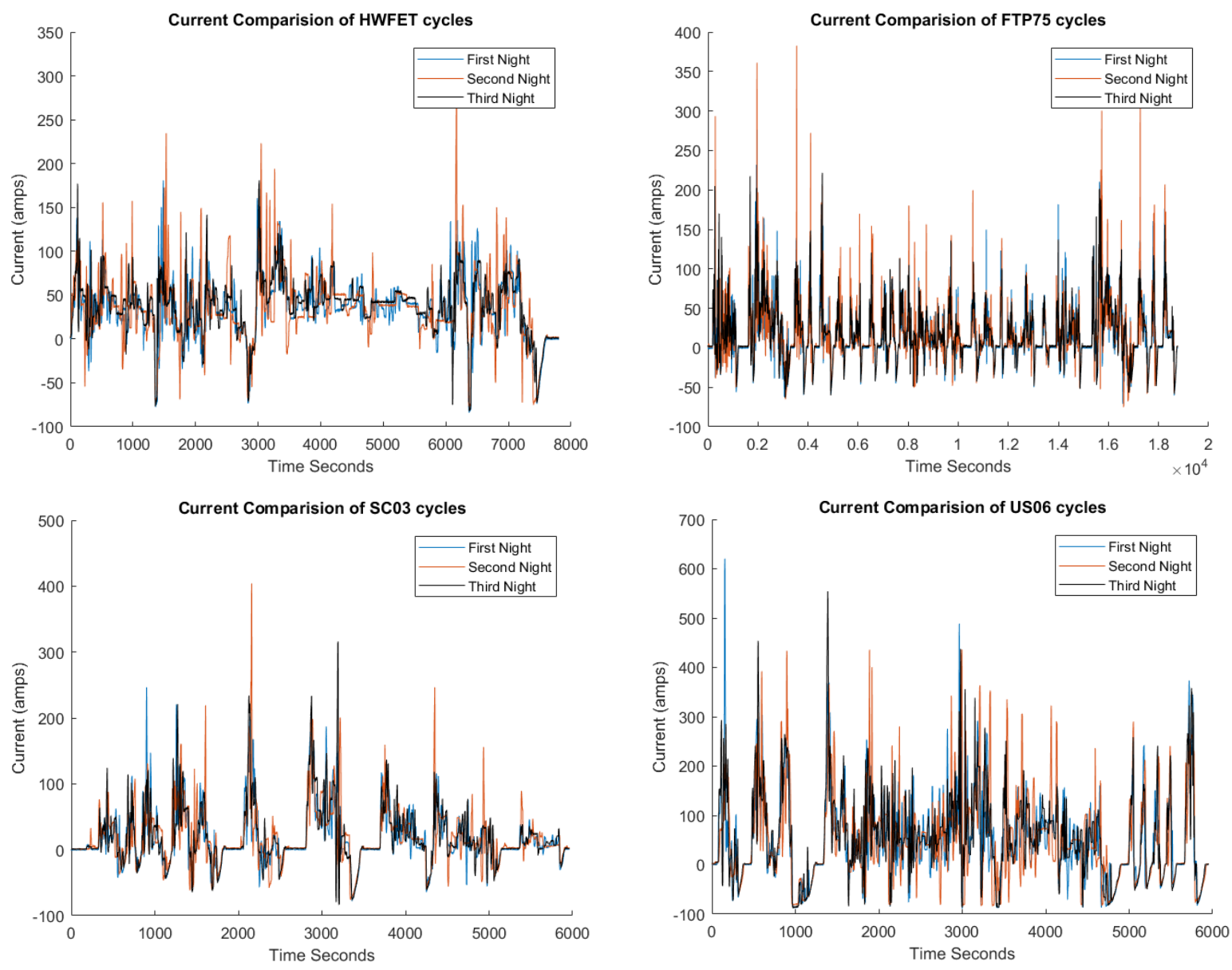

Figure 15 Current Data for Three Nights of Testing

The voltage data seen in Figure 16, shows that the second evening had a freshly charged battery. After the first night of testing the BEV was put on the charger overnight. The second night showed operational voltages much higher than the other two nights. 

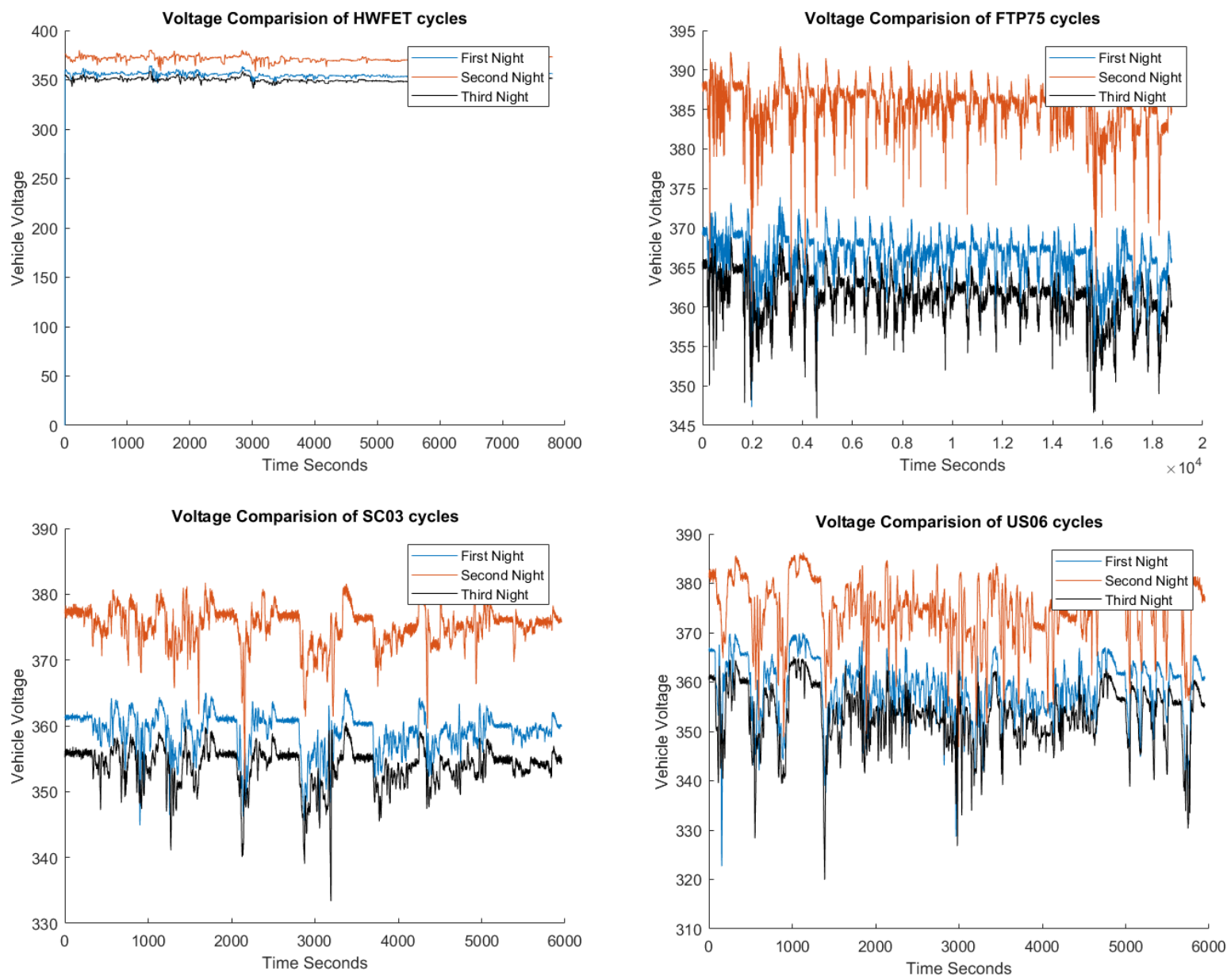

Figure 16 Voltage Data for Three Nights of Testing

In Figure 17, the energy consumption of the BEV is shown. The first night of testing consumed less energy than the second and third night of testing. 

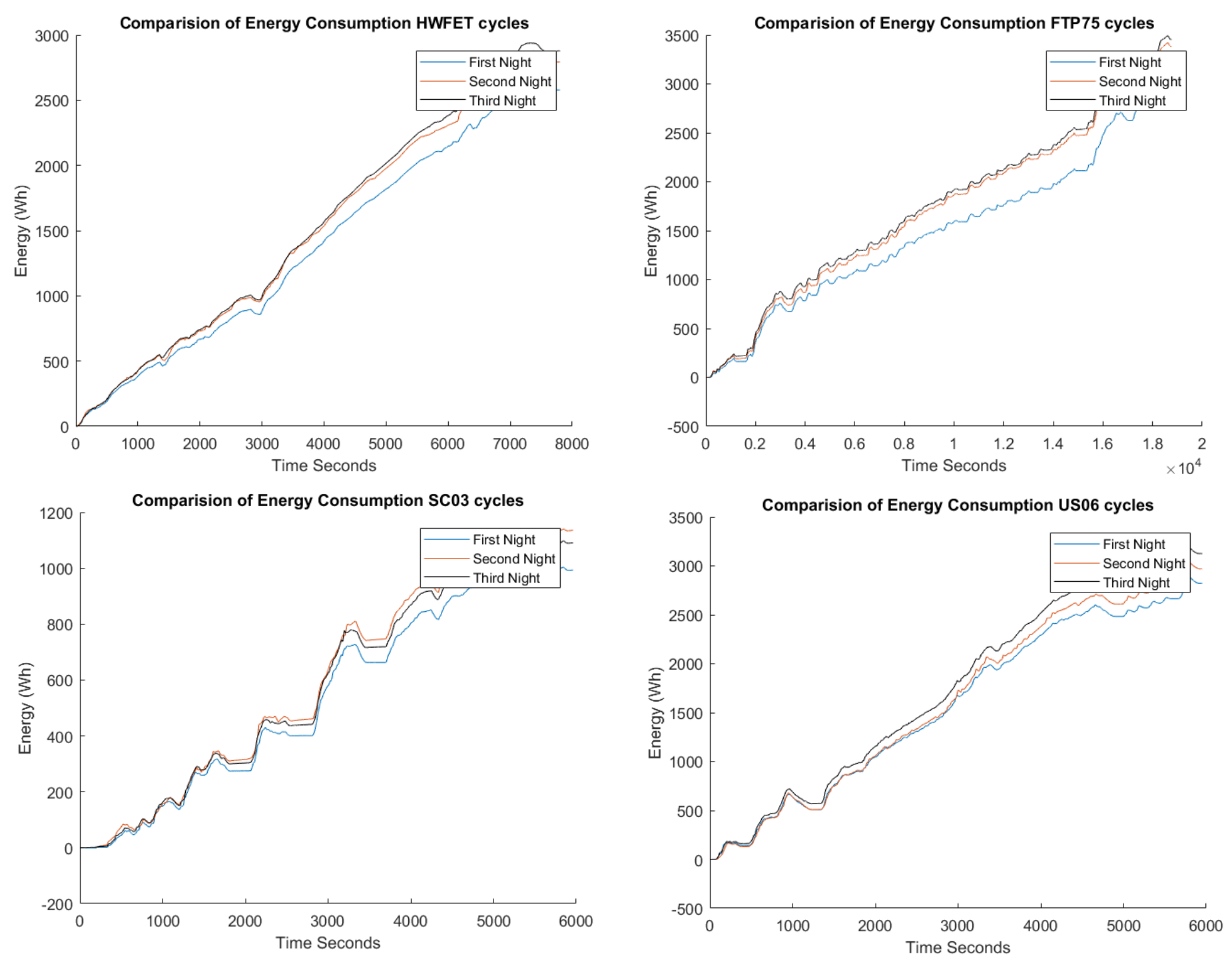

Figure 17 Energy Data for Three Nights of Testing

Observing the vehicle speed graph, Figure 14, there is variability between the three nights of testing. The HWFET test cycle showed the most variability between the vehicle speeds. Differentiating the vehicle speed yields vehicle acceleration. Comparing an enlarged graph of current and acceleration depicts a better picture of driver behavior.

Figure 18, shows the vehicle acceleration and the current consumption on the first night of testing with driver 1 . The shape of the acceleration graph resembles the shape of the current graph. This shows that driver 1 on the first night of testing gradually applied the accelerator pedal in the vehicle. There were no sudden accelerations. 

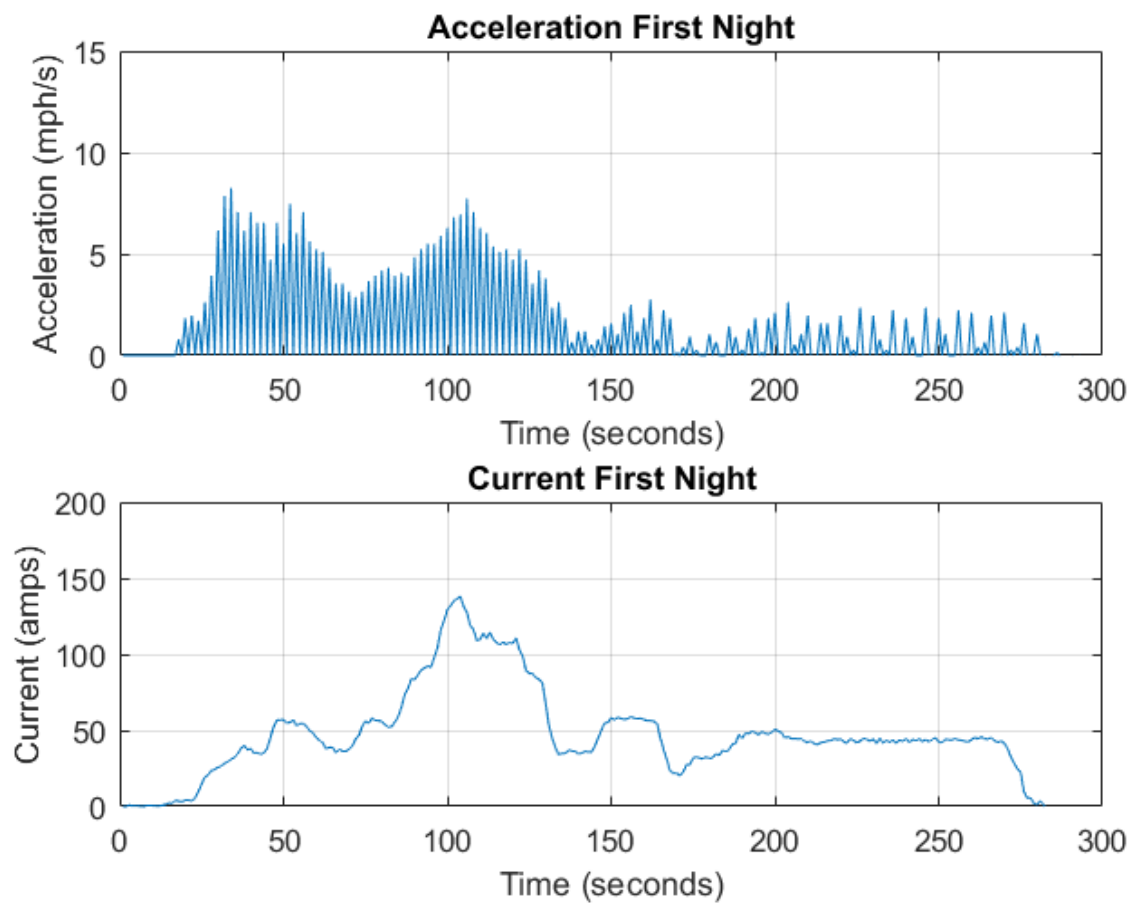

Figure 18 The First 30 Seconds of HWFET on the First Night

Figure 19 shows the first thirty seconds of the HWFET cycle, on the second night of testing with driver 2 driving the test cycle. The acceleration and the current graph do not follow the same trend as the first night did. Within the first five seconds there is a heavy acceleration followed by inconsistent acceleration that does not follow the trend of the current. This shows that driver 2 was heavy on the accelerator with more aggressive positive and negative acceleration. 

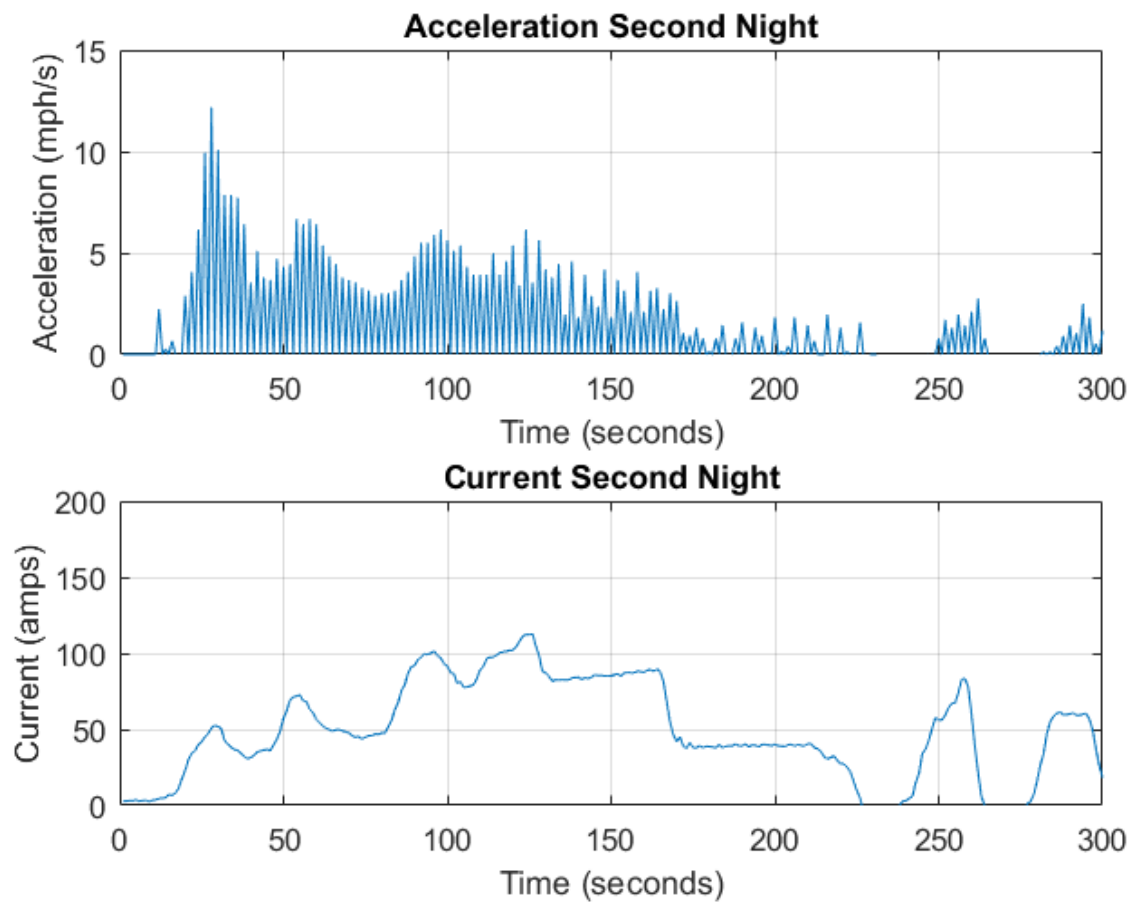

Figure 19 The First 30 Seconds of HWFET on the Second Night

Figure 20 shows the first thirty seconds of the HWFET cycle on the third night of testing, driven by driver 1. It can be seen within the first ten seconds of the test that the acceleration graph and the current graph do not align. This shows that on the third night of testing driver 1 was heavy on the accelerator and not as smooth as the first night of testing. 

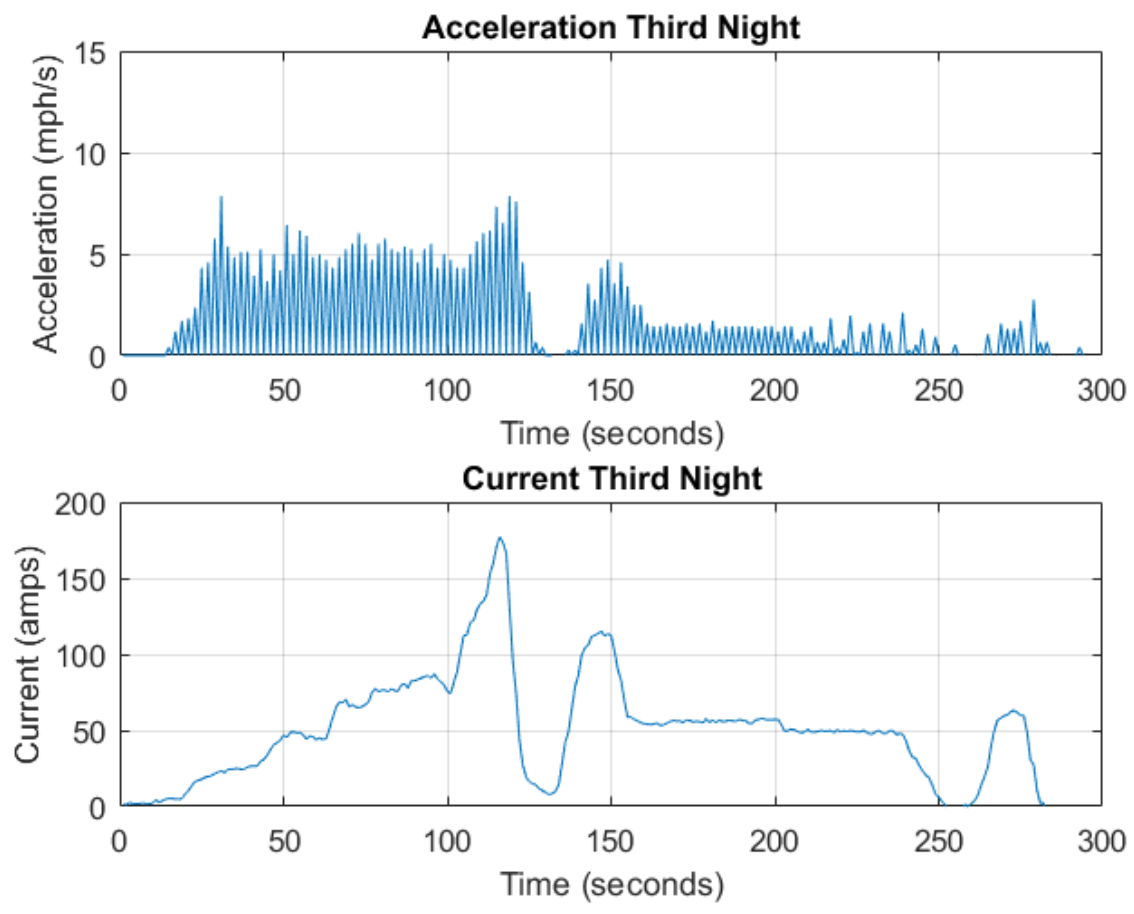

Figure 20 The First 30 Seconds of HWFET on the Third Night

The first evening had the highest rated fuel economy, and the lowest cost of the three nights. refer to

Table 2, Table 3,

Table 4.

\subsection{Measurement Uncertainty Error}

As previously stated the current clamp has an uncertainty error of $\pm 2.5 \%$, the voltage probe has an uncertainty of $\pm 2 \%$. This uncertainty can affect the accuracy of the overall energy consumption since the current and the voltage measurements are used in the total energy consumption. These systematic errors can propagate throughout the calculation.

Referring to Equation 2, the error for the Edc must be calculated as an upper bound and a lower bound.

$$
E d c=\frac{1}{3600 * f} * \sum_{j=0}^{n}\left(V_{j} \pm 0.02\right) *\left(i_{j} \pm 0.025\right)
$$

Equation 3 Edc With Uncertainty Error 
Equation 3 can be expanded into a lower bound and an upper bound.

Equation 4 shows the lower uncertainty bound using the lower error.

$$
E d c=\frac{1}{3600 * f} * \sum_{j=0}^{n}\left(V_{j}-0.02\right) *\left(i_{j}-0.025\right)
$$

Equation 4 Edc Lower Uncertainty Bound

Equation 5 shows the upper uncertainty bound using the upper error.

$$
E d c=\frac{1}{3600 * f} * \sum_{j=0}^{n}\left(V_{j}+0.02\right) *\left(i_{j}+0.025\right)
$$

Equation 5 Edc Upper Uncertainty Bound

Equation 6 expands the Edc uncertainty error for the upper and the lower bounds.

$$
\begin{gathered}
E d c=\frac{1}{3600 * f} * \sum_{j=0}^{n}\left(V_{j} * i_{j}\right) \pm\left(0.02 * i_{j}\right) \pm\left(0.025 \pm V_{j}\right) \\
+0.0005
\end{gathered}
$$

Equation 6 Expands the Uncertainty Error for Edc

Plotting the upper and lower bounds from Equation 6 along with the measured Edc will show an error plot to see how accurate the measurements are. Ideally the measured Edc will be between the upper and lower bounds. Figure 21 shows the uncertainty error plot for the third night of testing of the US06 cycle. 


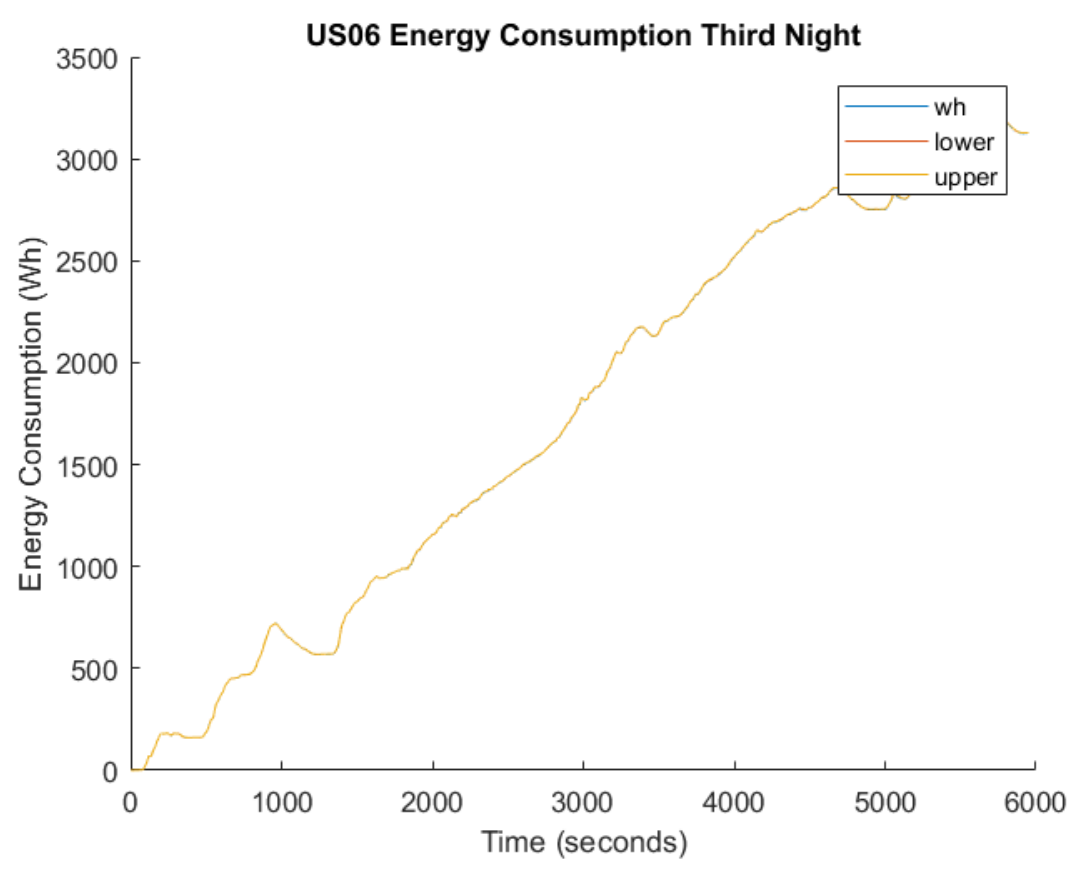

Figure 21 Edc Uncertainty Error Plot for US06 on the Third Night of Testing

Figure 22, shows a zoomed in portion of Figure 21. The measured energy is outside of the bounds of the upper and lower limits of the uncertainty error. This indicates that the error in the measurement instruments propagated throughout the calculations leading to a less accurate energy consumption calculation. 


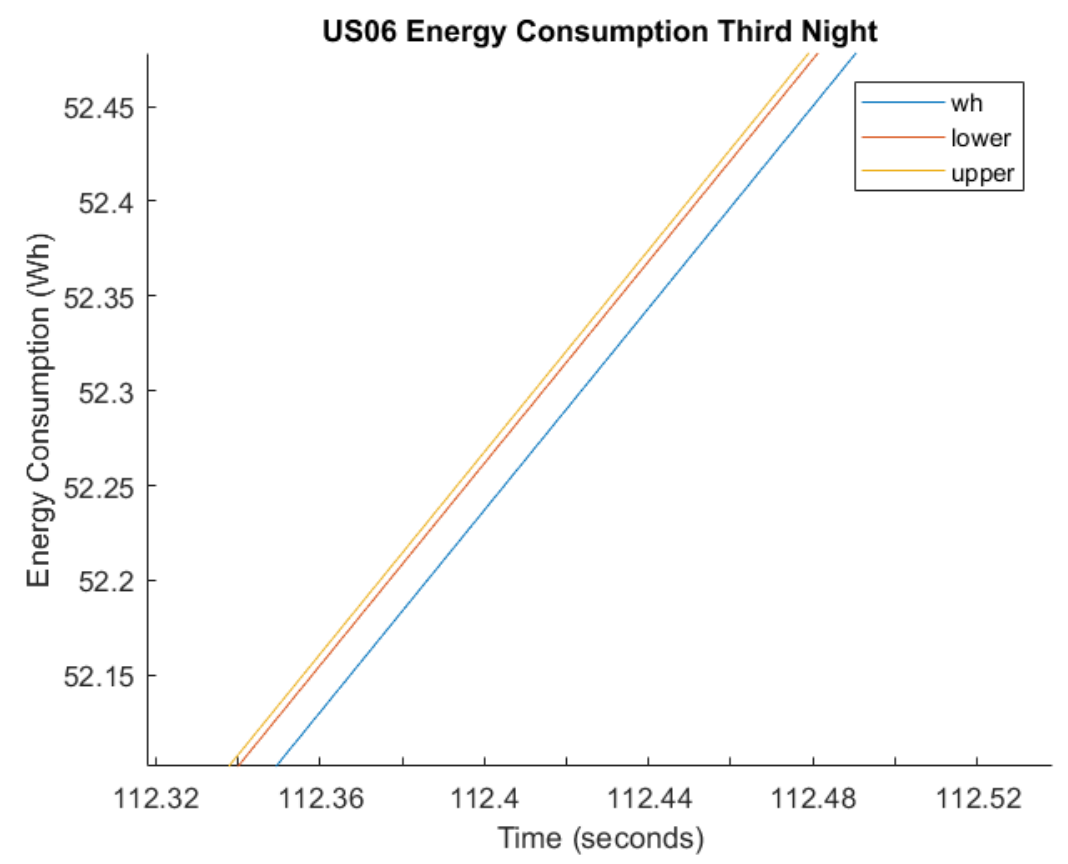

Figure 22 Zoomed in Edc Uncertainty Error Plot for US06 on the Third night of Testing

\section{Battery Emission}

\subsection{Sampling Manifold Construction}

The battery pack on the 2013 Tesla Model S is located underneath of the vehicle. It was desired to see if the battery pack produced any emissions while under electrical loading. After the underside of the vehicle was examined a vent cover was located and removed, Figure 23. Underneath the vent covering were three orange diaphragm one-way vents. These vents went directly into the battery pack of the BEV. 


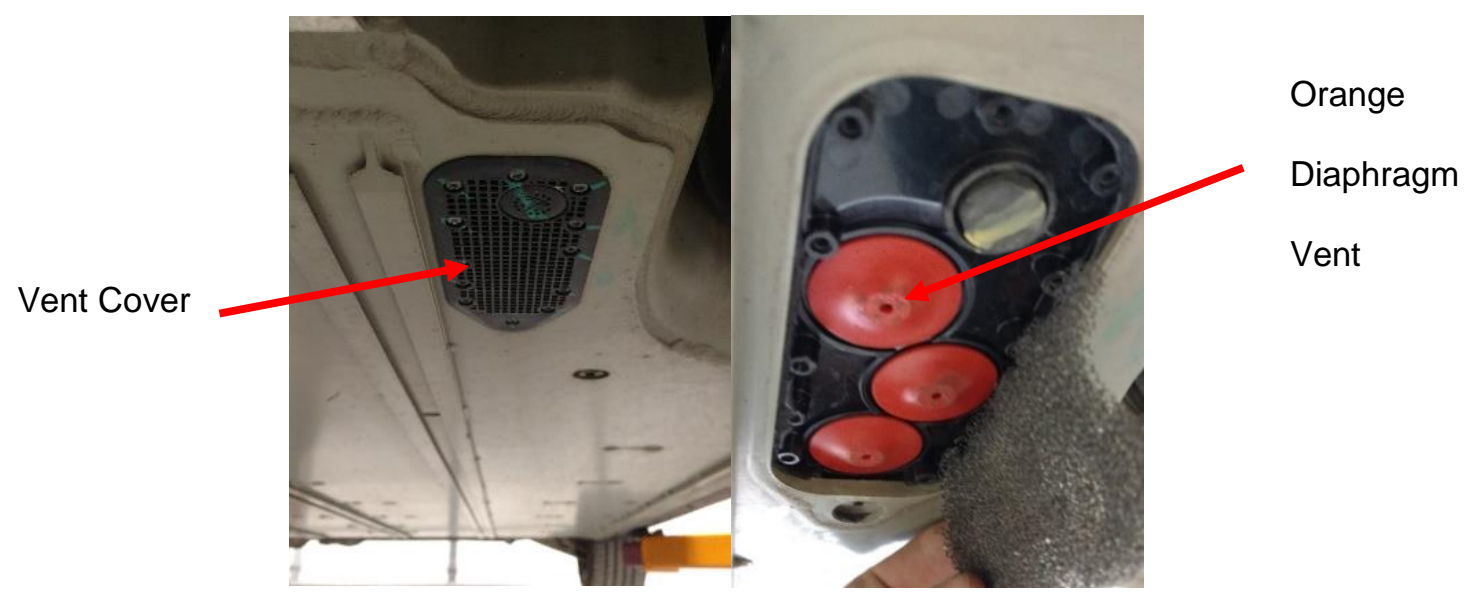

Figure 23 The ESS Vent Covered, Left. Uncovered, Right

A sample manifold was created to cover the vent on the bottom of the battery pack. The bolt pattern on the bottom was designed to match up to the bolt pattern of the vent. Two half couples were welded into the side of the sample manifold so various sampling equipment could be attached. The top cover, attached with six machine screws sealed off the box, Figure 24. The flat mating surfaces of the box were covered with room temperature vulcanizing (RTV) gasket maker to create a seal.

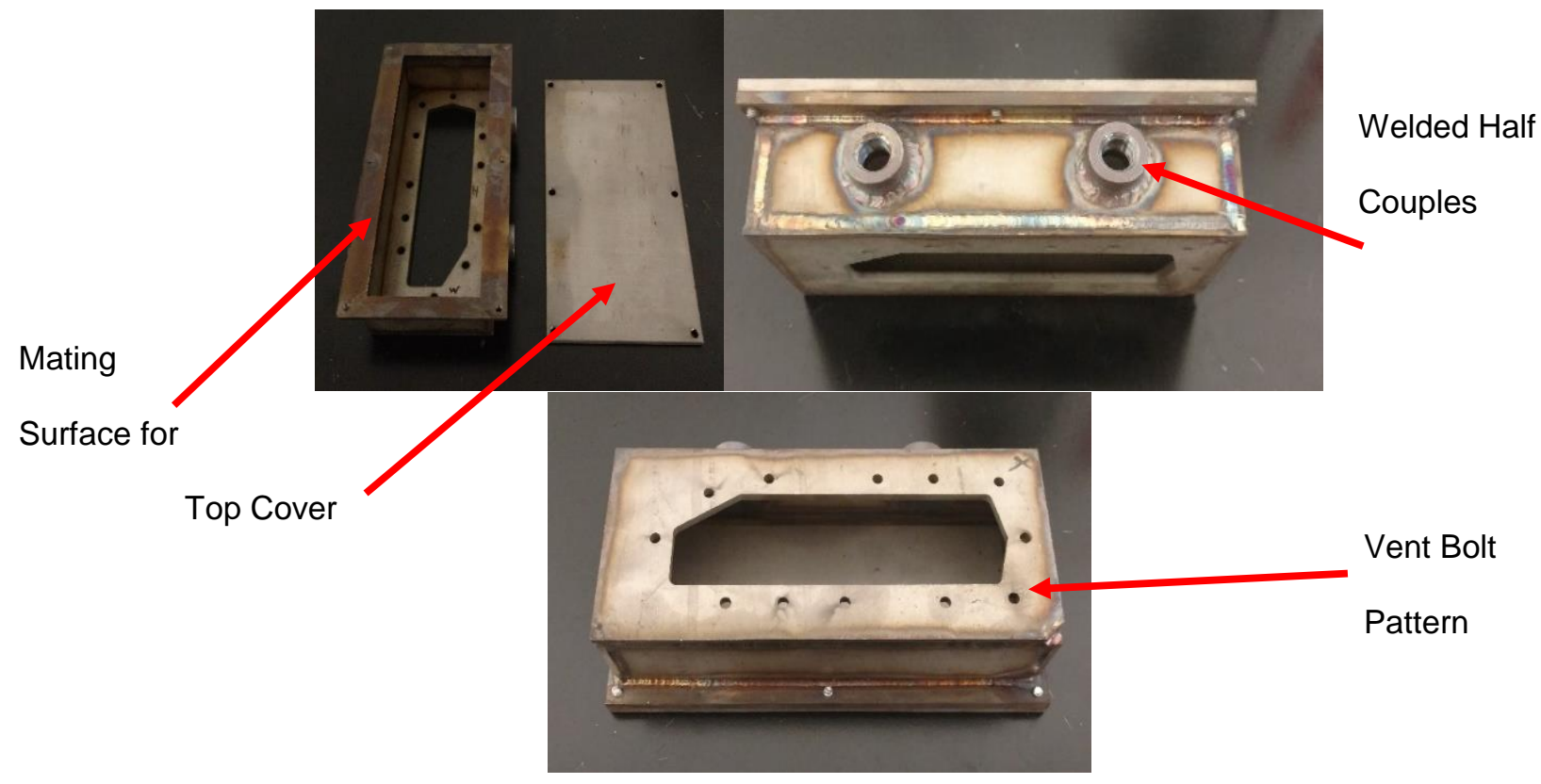

Figure 24 Clockwise from Top Left: The Sample Manifold and Cover. The Inside of the Sample Manifold. The Bottom of the Sample Manifold 


\subsection{Dynamometer Sampling}

\subsubsection{Sampling}

A total of twelve gas samples were collected from the BEV; three samples from the battery during charging at $208 \mathrm{~V}$, three control samples (sampling air) during charging, three samples from the battery during discharging (operation on the dynamometer), and another three control samples of ambient air from the dynamometer test cell.

The samples were collected by connecting a Swagelok stainless tube to one port of the sampling manifold. The other port of the sampling manifold was sealed off. A zero to five liter per minute (Ipm) variable pump was set at one Ipm to sample while the BEV charged. The inlet of the sample pump was connected to the manifold under the vehicle. The outlet of the pump was connected to a Tedlar ${ }^{\circledR}$ sample bag. Figure 25, below, shows the sample pump connected to the Swagelok and the Tedlar bag.

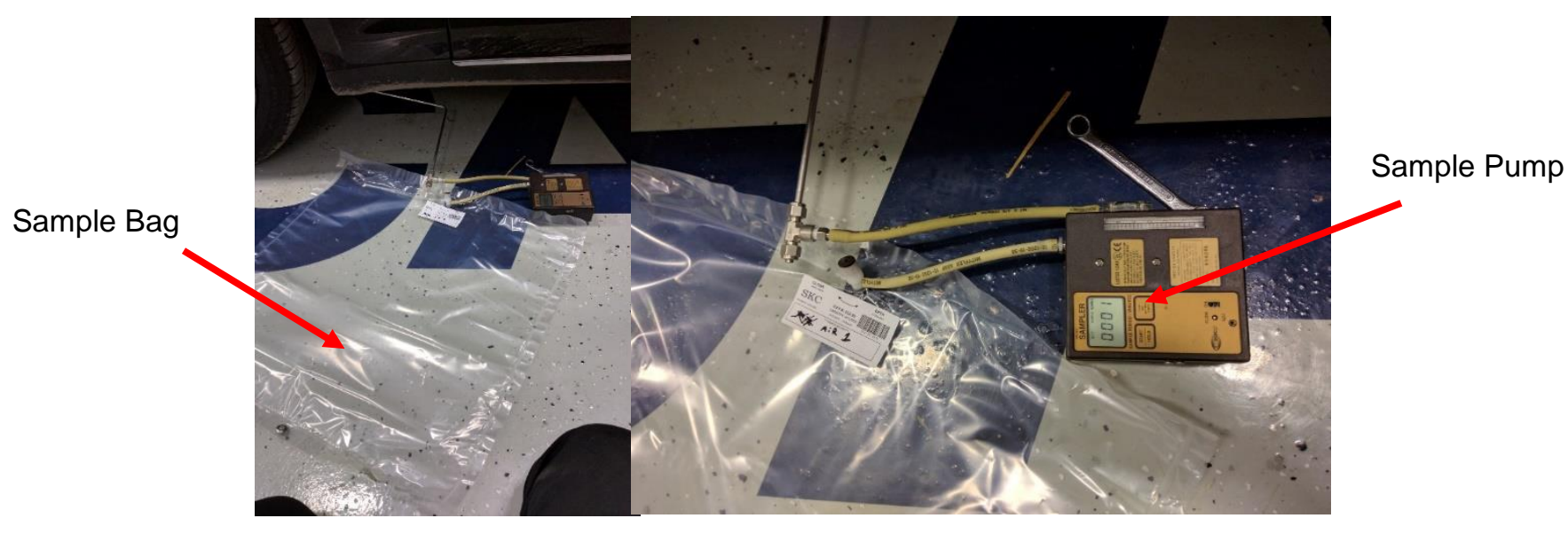

Figure 25: Battery Sampling during Charging at 208 Volts

Figure 26, below, shows the sample manifold in place under the vehicle while on the dyno, circled in red. The left port of the manifold is plugged, the right port on the manifold goes to the sampling pump system. 


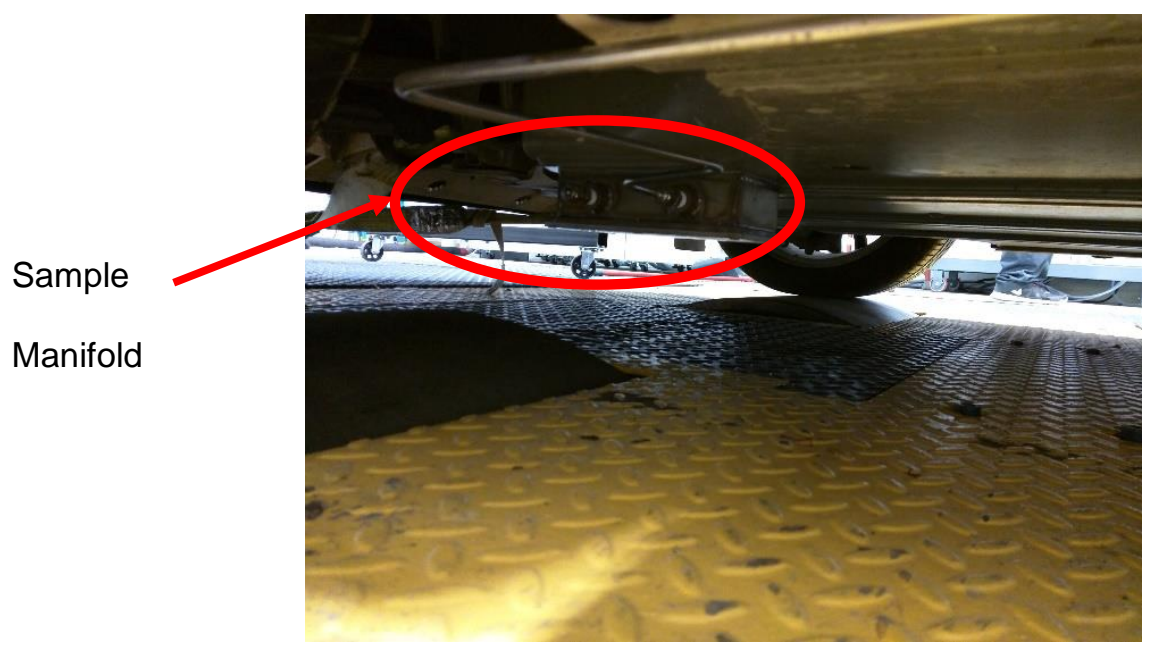

Figure 26: Battery Sample Manifold Installed on the BEV

Figure 27 shows the BEV secured to the four-wheel eddy current dyno, provided by CAFEE.

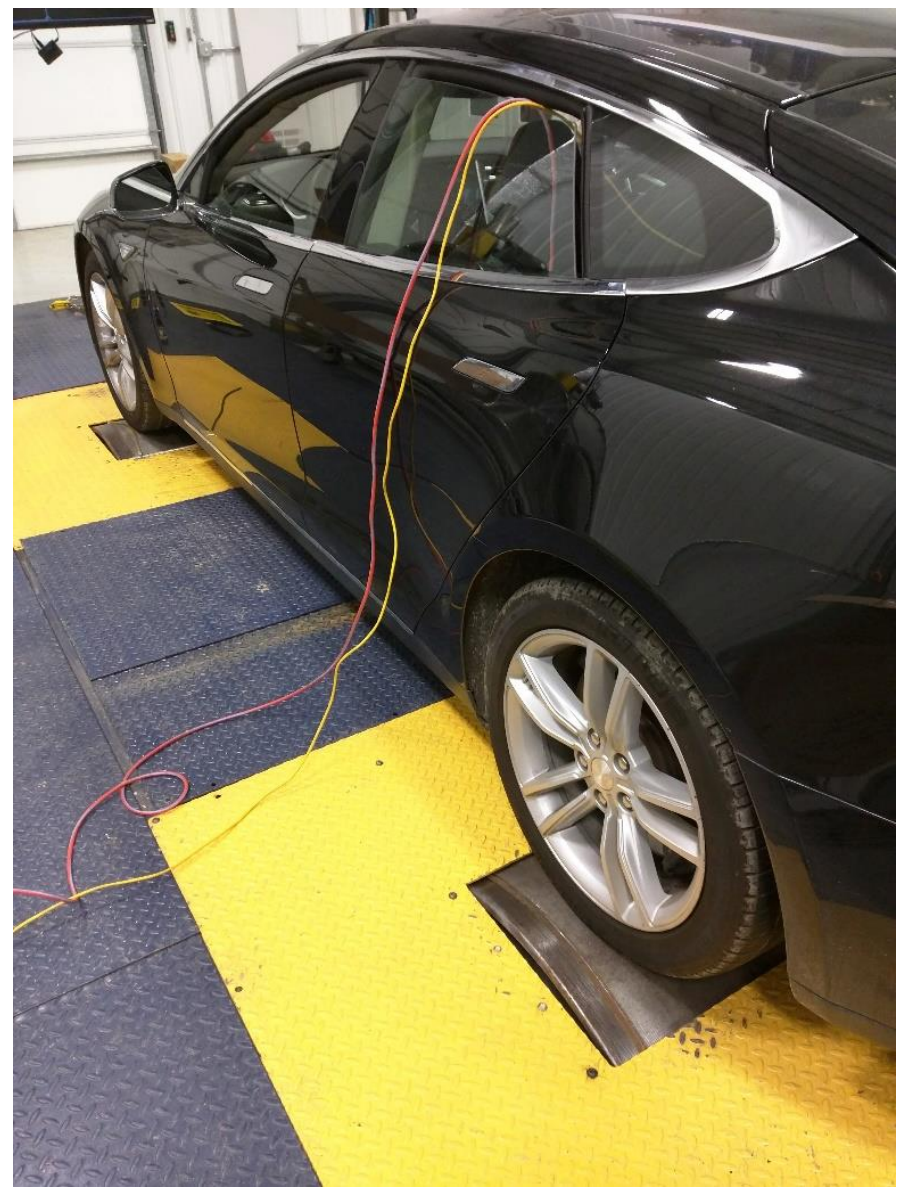

Figure 27: BEV Secured to the Chassis Dynamometer 


\subsubsection{Results}

Several sample bags were sent to Southwest Research Institute (SwRI) for gas chromatograph (GC) analysis, Appendix C, Appendix D. The sample analysis included total fluorine, permanent gases, and light hydrocarbons. They also performed a T015 test, which can identify 60 species of volatile organic compounds.

SwRI detected elevated ethane concentrations from one of the sample bags. Ethane was the only compound SwRI tested that the in-house FTIR was also able to detect. Southwest Research Institute detected a maximum concentration of ethane at $27.3 \mathrm{ppm}$ in one of the in-use samples derived from the Tesla during the supercharging trip. A supercharger is a Tesla term for a public charging station. Tesla has created a network of around 1,000 Superchargers in North America. The Superchargers allow the driver to recharge their vehicle quickly when a home charger is not available.

\subsection{Supercharge After Towing}

The BEV was transported by a flatbed tow truck up to a supercharging station in Triadelphia, WV. This was to see how the vehicle behaved during supercharging while all the components were at ambient temperature. The network of supercharging stations across the United States alone consists of 828 Supercharger Stations with 5,339 individual Superchargers. The Supercharging stations can deliver $120 \mathrm{~kW}$ of power to the battery pack, slowly tapering the charge as the battery fills up [27] Figure 28, Figure 29.

The ambient temperature for the trip was approximately $40^{\circ} \mathrm{F}$ and it was assumed that the battery pack was at equilibrium with the ambient surroundings. The batteries as well as the motor were unused during the trip. 


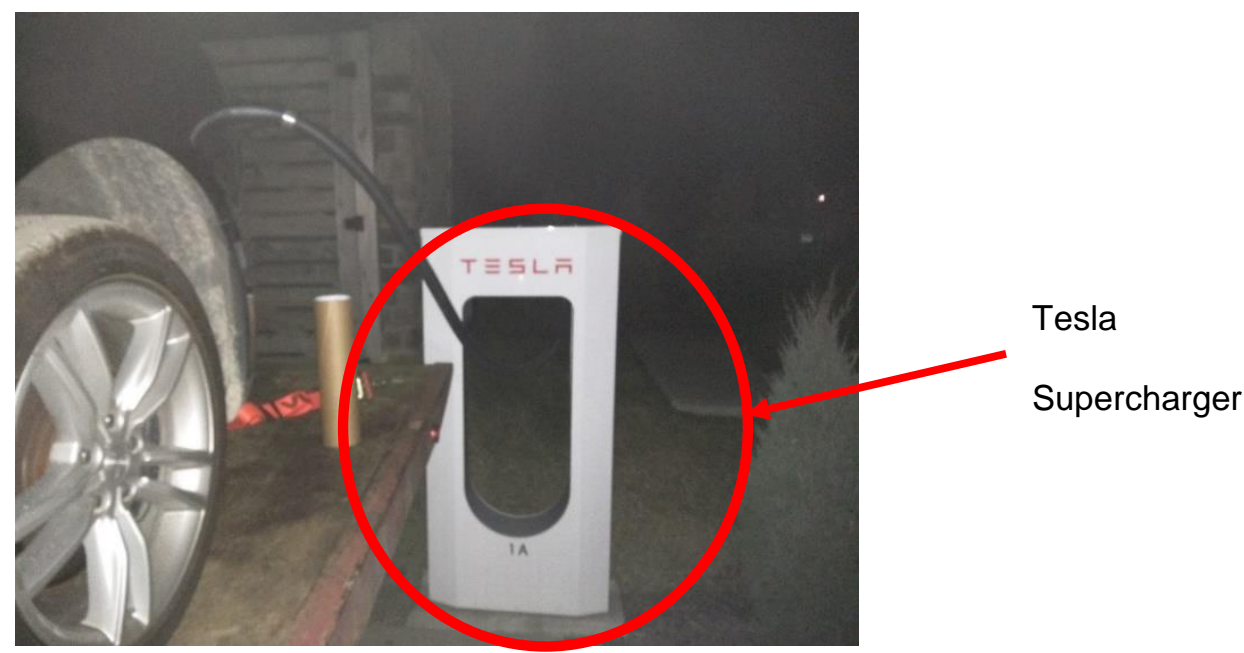

Figure 28 Supercharging the BEV While on the Tow Truck

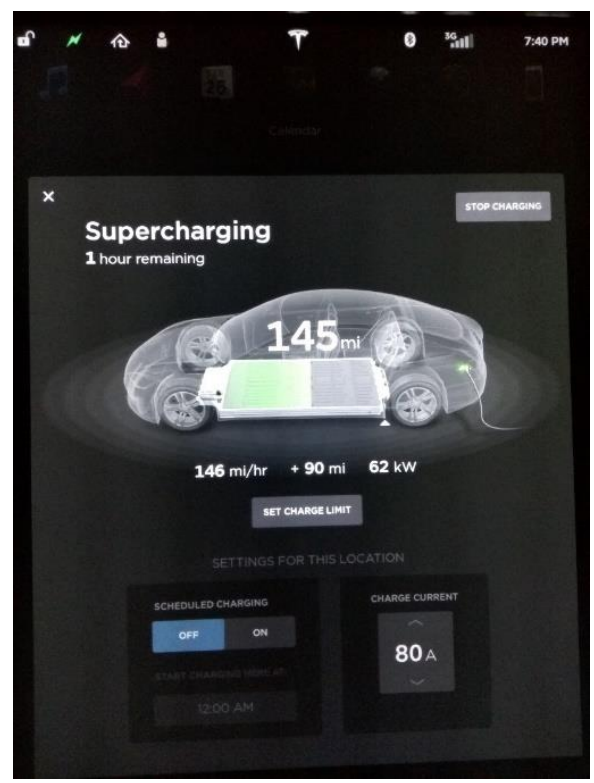

Figure 29 Main Display Indicating that the BEV is Supercharging

Samples were taken of the ambient air at the supercharging station as well as battery samples. A flow meter was connected to the sampling manifold to measure if the battery pack emitted gases during supercharging. It can be seen in, Figure 30 below, that the battery pack was flowing at a rate of $0.2 \mathrm{lpm}$. 


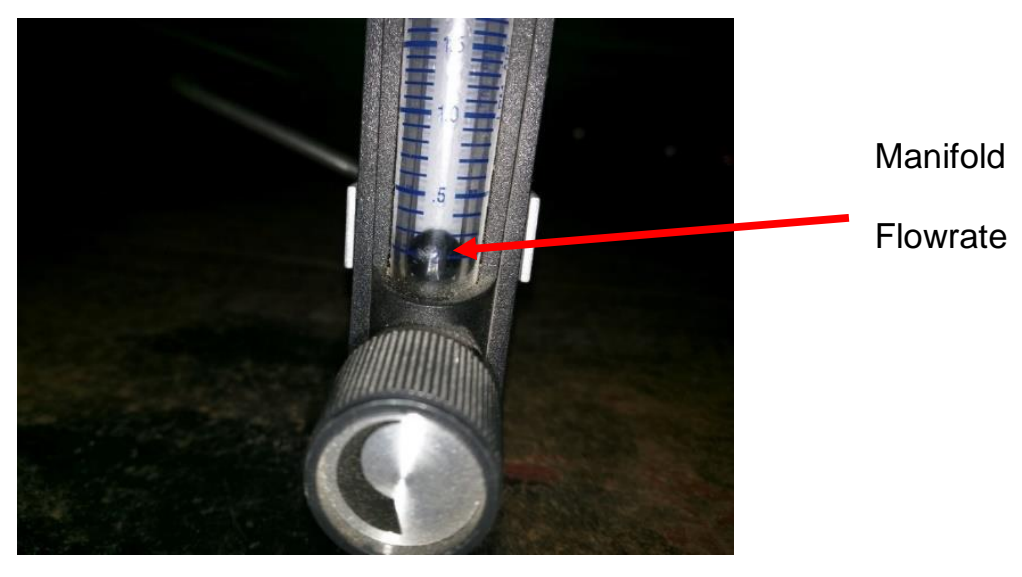

Figure 30 Rotameter Connected to Sample Manifold as ESS

Flows

The graphs below show the analysis of gaseous components found in the samples taken from the battery while supercharging. The compounds listed were, at first glance, significantly higher than their ambient air counterparts. All the below graphs were sampled through an MKS FTIR, at the in-house CAFEE location.

Figure 31 shows that the percent of carbon monoxide found in the battery sample is about four percent higher than the sample taken of the ambient air. The graphs have a rise in them, meaning that the values slowly increase until they stabilize. It takes the analyzer several seconds to respond. The stabilized value is what is in the sample bag.

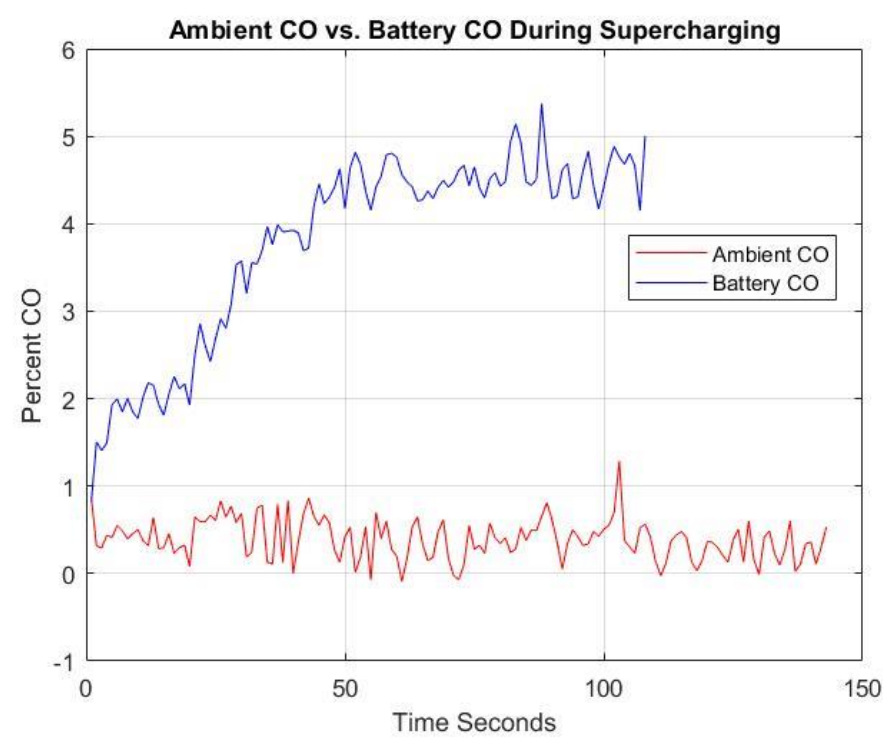

Figure 31 Ambient Carbon Monoxide vs. Battery Carbon Monoxide 
Figure 31 shows that the percentage of Carbon Dioxide between the battery sample and the ambient sample is about $0.6 \%$

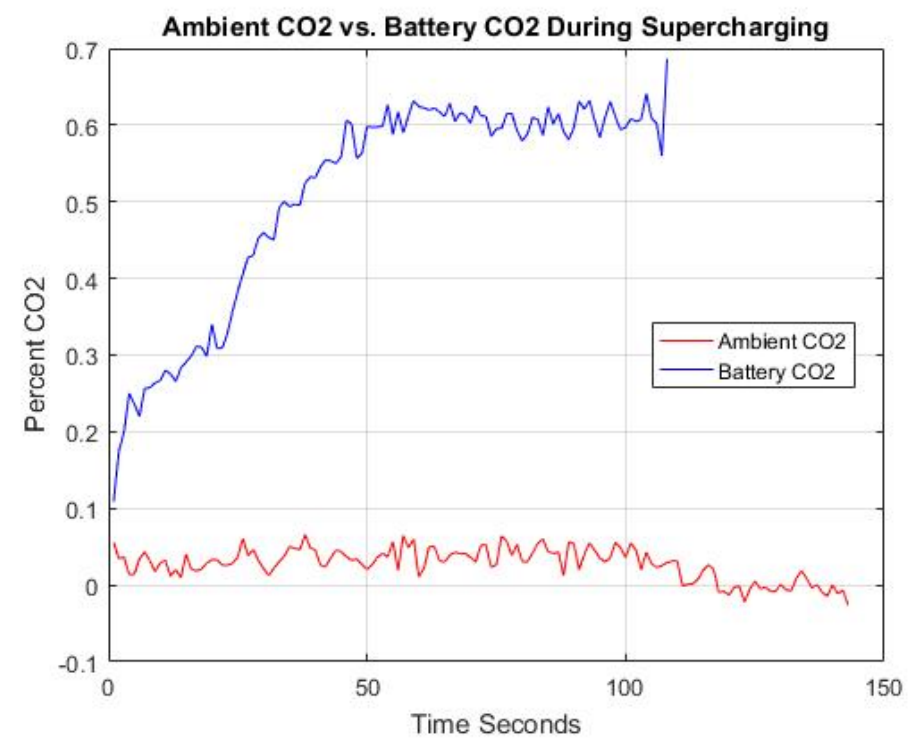

Figure 32 Ambient Carbon Dioxide vs. Battery Carbon Dioxide

Figure 33 shows that the concentration in parts per million (ppm) of the battery propylene was thirteen ppm higher than the ambient propylene.

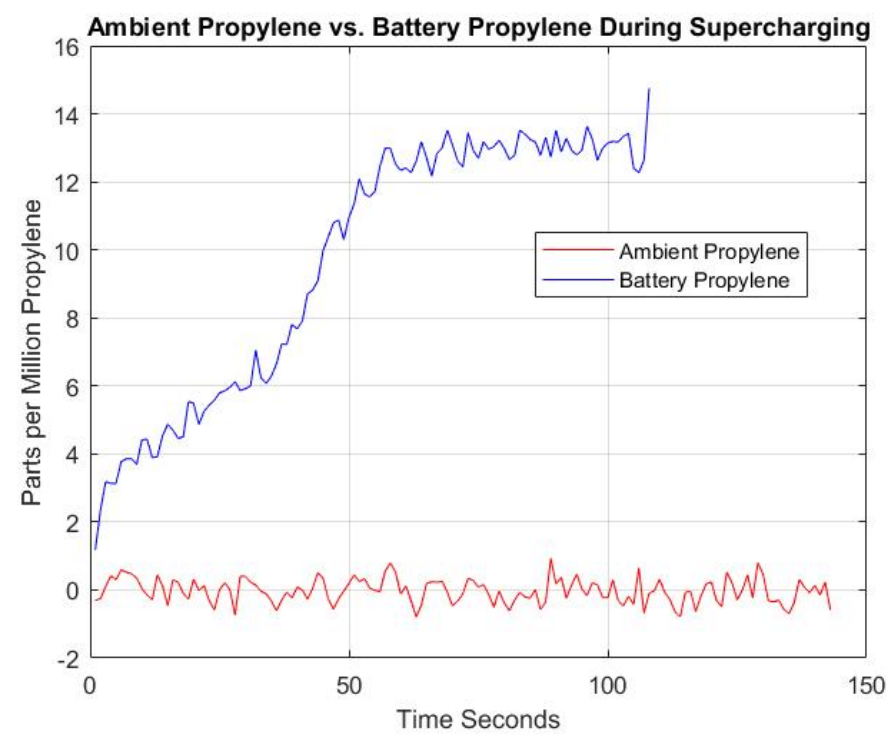

Figure 33 Ambient Propylene vs. Battery Propylene

Figure 34 shows that the battery butane is approximately five ppm above the ambient sample. 


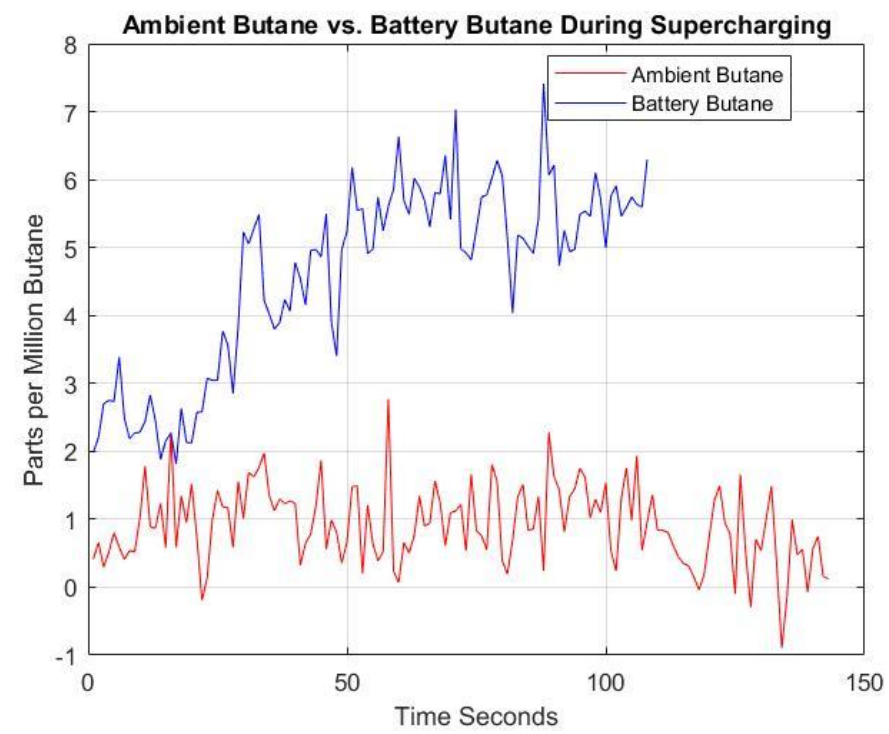

Figure 34 Ambient Butane vs. Battery Butane

Figure 35 shows that the ambient methane is about seventy percent higher than the ambient methane.

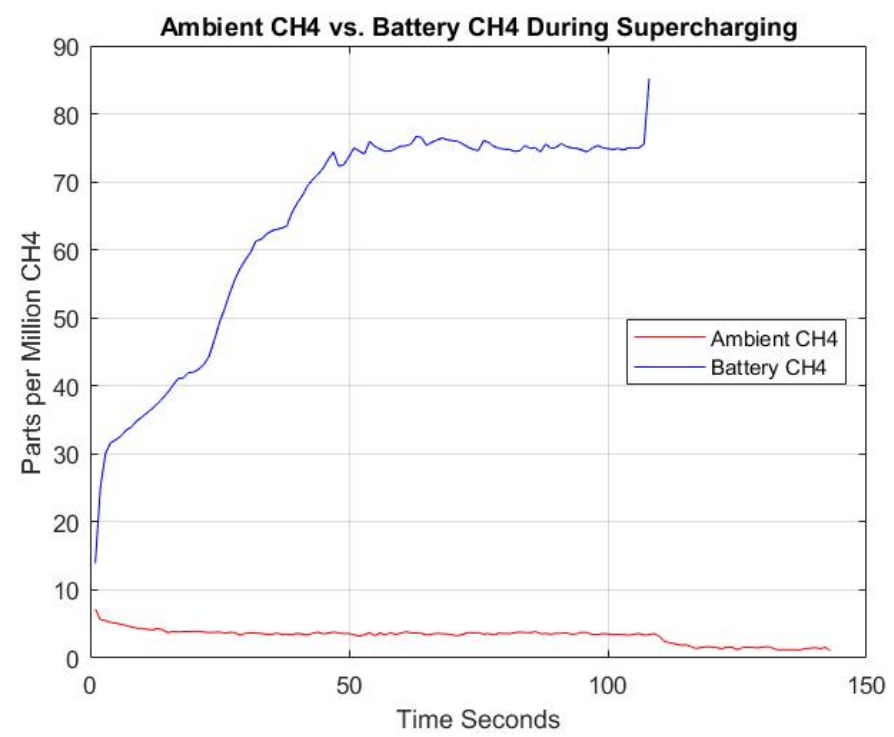

Figure 35 Ambient Methane vs. Battery Methane

\subsection{Second Supercharge Trip}

\subsubsection{Sampling}

Another trip was taken to the supercharging station in Triadelphia, WV. The BEV was driven to heat up the battery pack and the vehicle components. Two bags were sampled with the pump, two were 
sampled without the pump, and two controls were taken at the supercharging station. This gave a wider sample set.

\subsubsection{Results}

The six samples were analyzed by the FTIR. Each graph below shows two lines of each: ambient air, battery sample using the pump, and battery sample without the pump. The battery samples using the pump forced flow out of the battery pack into the sample bags, while the battery samples without the pump used the flowrate from the charging ESS to fill the sample bags. Figure 36 shows a graphical overlay of the six samples, comparing carbon monoxide (CO).

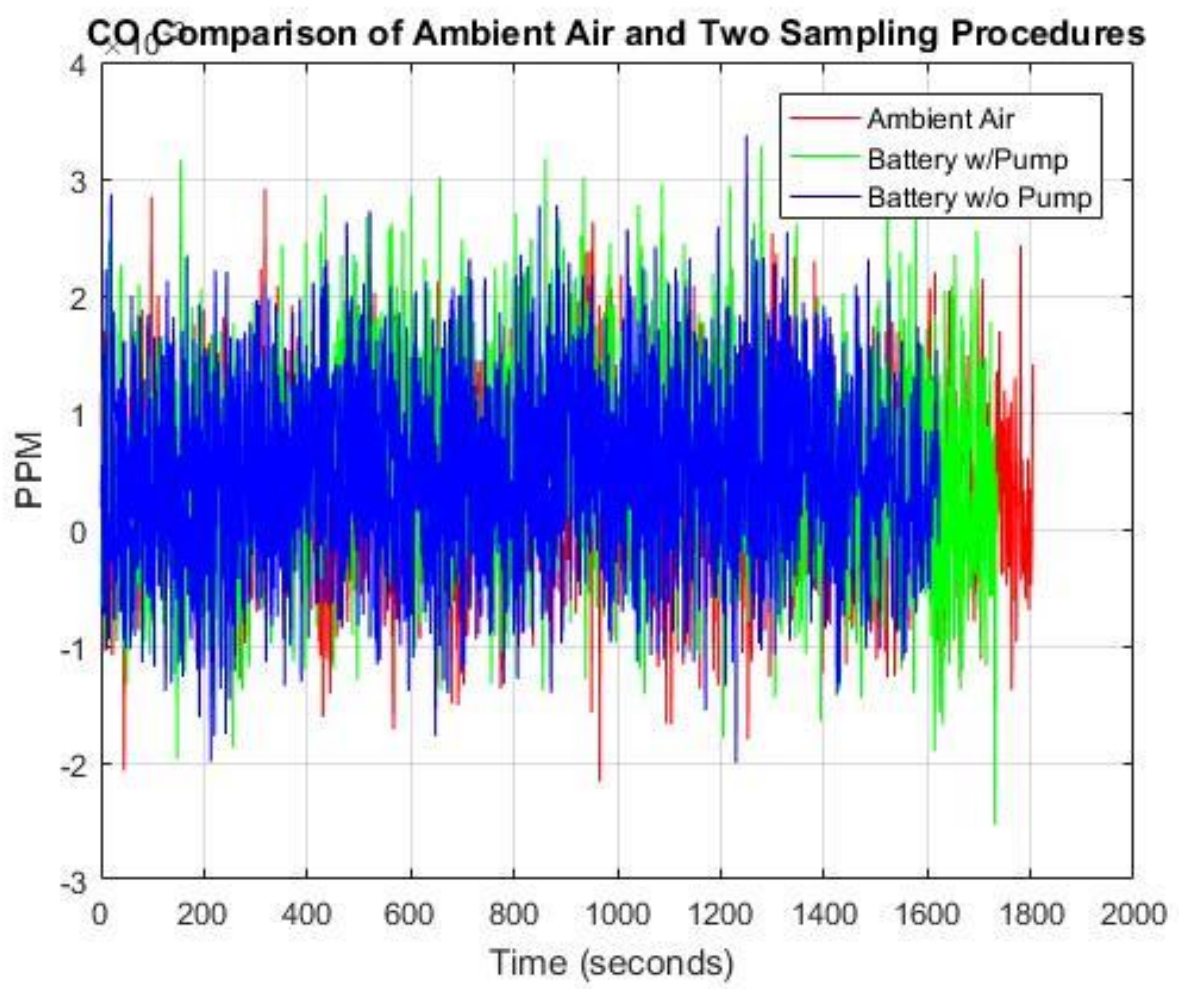

Figure 36 Comparison of the Three Tests for Carbon Monoxide

Figure 37 compares the percentage of carbon dioxide $\left(\mathrm{CO}_{2}\right)$ analyzed in the six samples. 


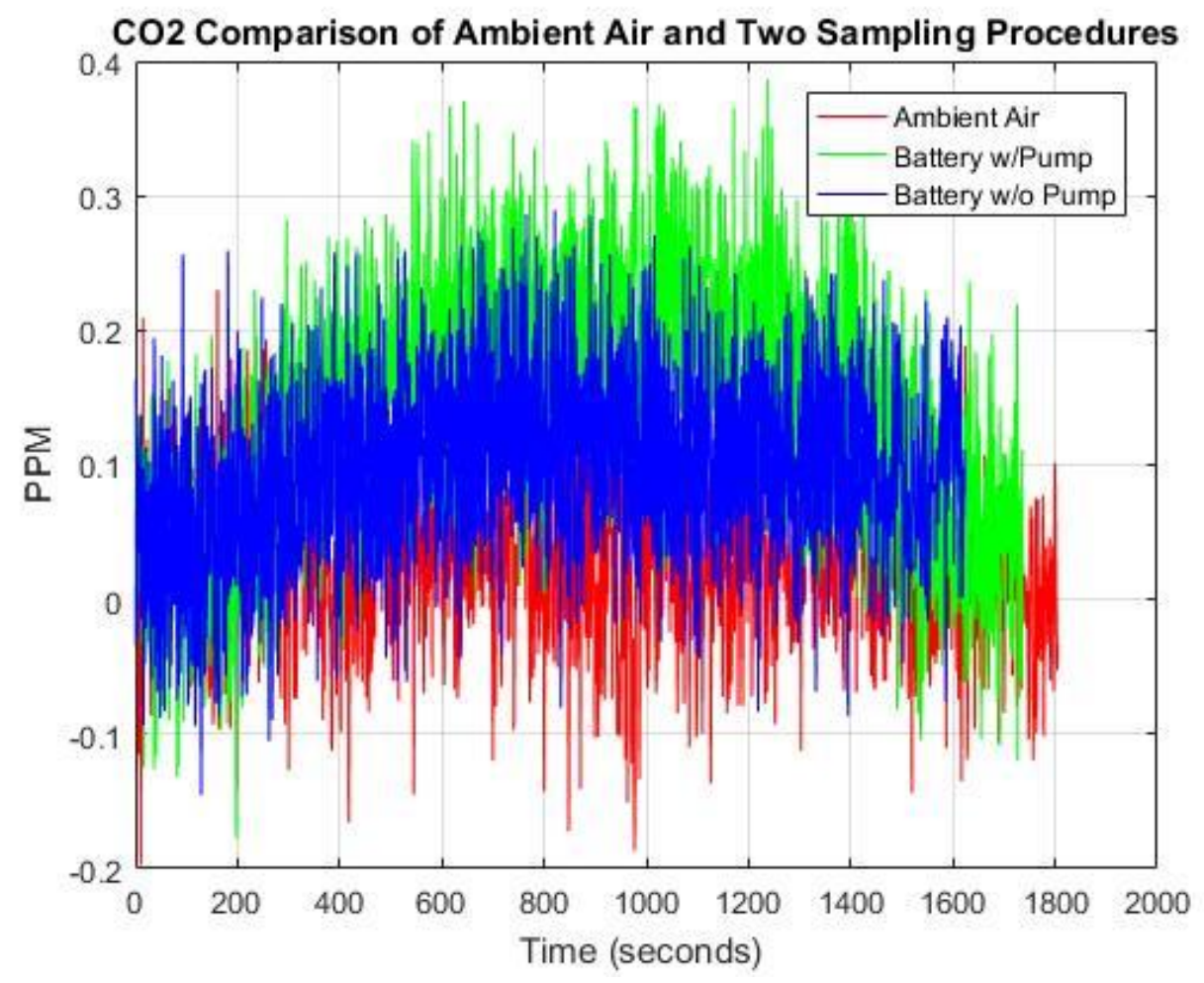

Figure 37 Comparison of the Three Tests for Carbon Dioxide

Figure 38 compares the propylene concentration of the six samples analyzed by the FTIR. It is observed that in this sample, both sample bags that were filled without the sample pump had an elevated concentration of propylene. 


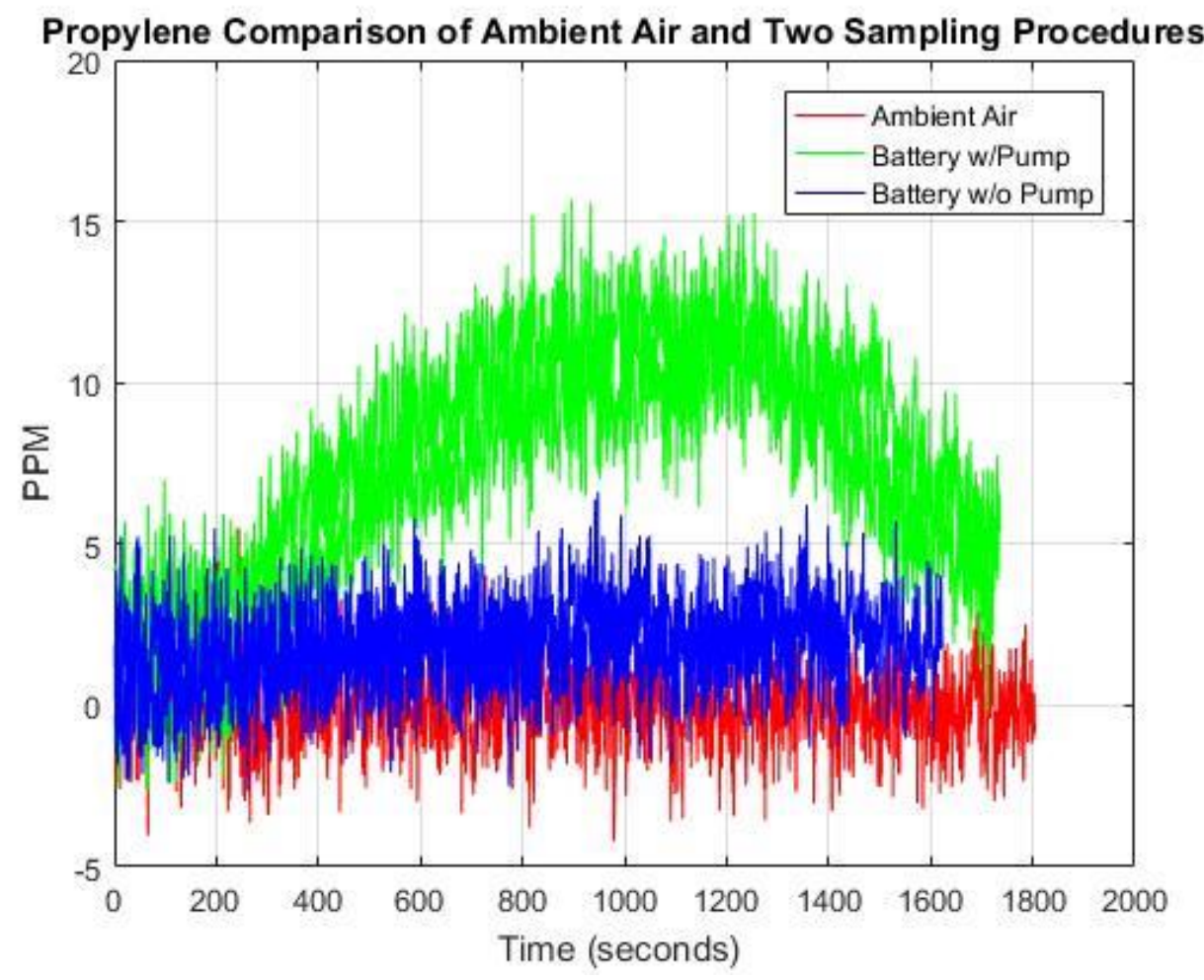

Figure 38 Comparison of the Three Tests for Propylene

Figure 39 compares the results of the control and the samples bags of butane. It is observed that the samples taken without the pump show elevated concentrations of butane. 


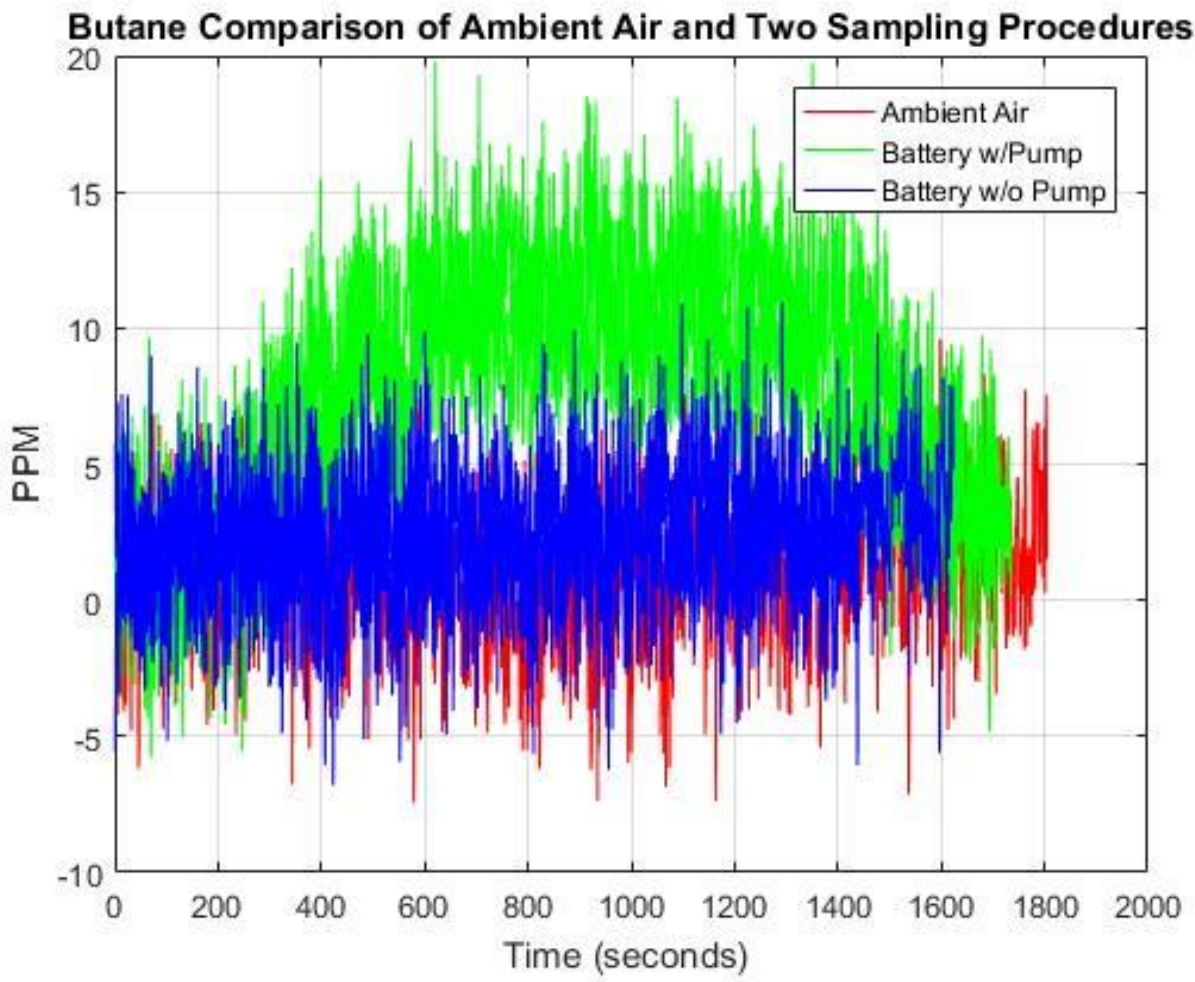

Figure 39 Comparison of the Three Tests for Butane

Figure 40, shows the comparison nitrogen dioxide (NO2) of the analyzed samples. 


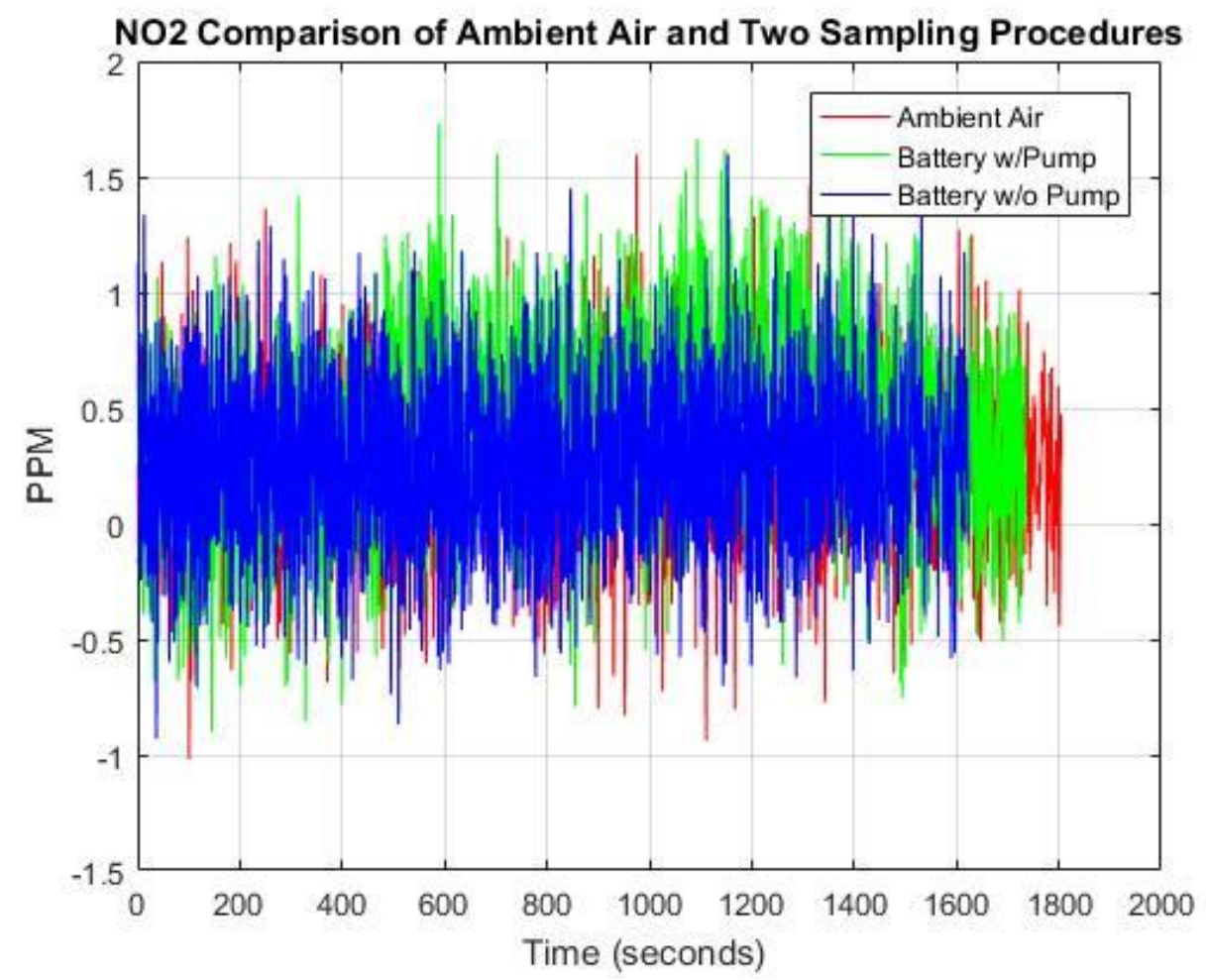

Figure 40 Comparison of the Three Tests for Nitrogen Dioxide

Figure 41, shows the comparison of the three samples for methane $(\mathrm{CH} 4)$. The samples taken without the pump, and with the pump show elevated concentrations when compared to the ambient control. 


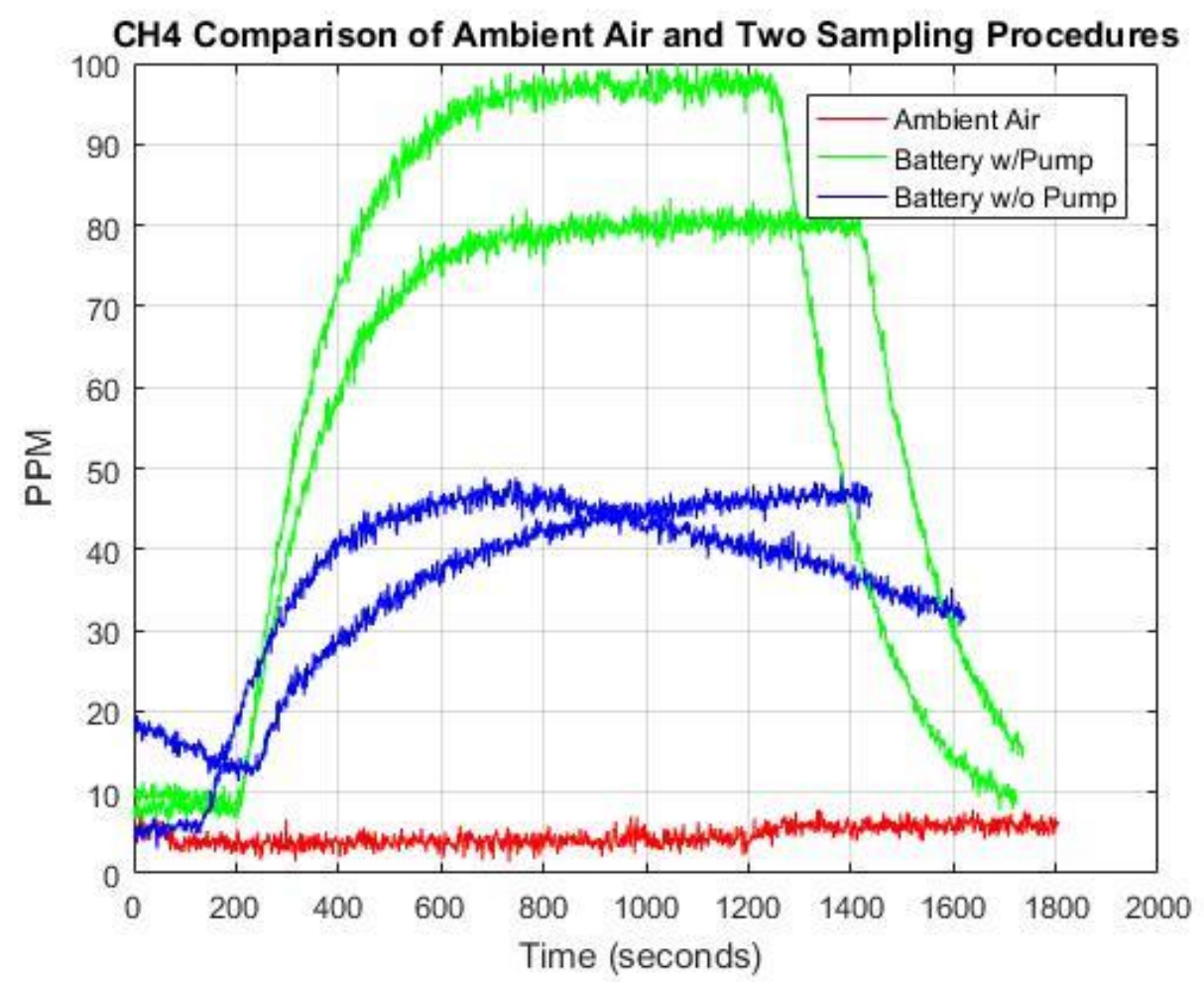

Figure 41 Comparison of the Three Tests for Methane

Table 5, below displays the max concentrations detected for each of the gaseous species displayed in the graphs above.

Table 5 The Max Concentrations Detected of Each Gaseous Species

\begin{tabular}{|l|l|l|l|l|l|l|}
\hline & CO2 (\%) & CO (\%) & $\begin{array}{l}\text { Propylene } \\
(\mathrm{ppm})\end{array}$ & $\begin{array}{l}\text { Butane } \\
(\mathrm{ppm})\end{array}$ & NO2 (ppm) & CH4 (ppm) \\
\hline Air & $2.45 \mathrm{E}-01$ & $2.91 \mathrm{E}-03$ & 5.51 & 9.62 & 1.59 & 7.9 \\
\hline $\begin{array}{l}\text { Battery with } \\
\text { Pump }\end{array}$ & $3.51 \mathrm{E}-01$ & $3.27 \mathrm{E}-03$ & 15.26 & 19.76 & 1.77 & 83.39 \\
\hline $\begin{array}{l}\text { Battery } \\
\text { without } \\
\text { Pump }\end{array}$ & $2.89 \mathrm{E}-01$ & $3.37 \mathrm{E}-03$ & 6.62 & 10.93 & 1.59 & 48.9 \\
\hline
\end{tabular}




\subsection{Driving Emissions}

\subsubsection{Sampling}

After the emissions were analyzed from the second supercharging trip it was desired to see if the ESS was producing gases as a result of battery stress, or if the flow rates previously seen were a result of gaseous expansion due to temperature change. It was noticed that after driving for a period with a sample bag attached directly to the sampling manifold the bag would inflate. Charles' Law, an adaptation of the ideal gas law states that the ratio of the initial and final temperatures are directly proportional to the temperature change for an ideal gas, Equation 7.

$$
V f=V i * T f / T i
$$

Equation 7 Charles' Law

Where:
$\mathrm{Vf}=$ =final volume
$\mathrm{Vi}=$ =initial volume
$\mathrm{Tf}=$ final temperature
$\mathrm{Ti}=$ initial temperature

An experiment was constructed to determine if the inflated bags were gases created from the batteries themselves, or if it was a result of temperature changes. A bag inflated with ambient air was attached to the sample manifold and the valve on the bag was open. Allowing the gases to freely increase or decrease in volume. The bag was left overnight and checked the next day.

\subsubsection{Results}

The weather forecast was consulted after leaving the bag overnight. The temperature on April 6th was $55^{\circ} \mathrm{F}$, and the temperature on April 7 th was $34^{\circ} \mathrm{F}$. The afternoon of the 6 th a sample bag was pumped full of air and connected to the sample manifold. The next day when the temperature was $20^{\circ} \mathrm{F}$ cooler, the bag was observed again after sitting overnight. Figure 42 shows the difference in the bag 
inflation. The left picture is the fully inflated sample bag, the picture on the right is the deflated bag after the temperature change occurred overnight.

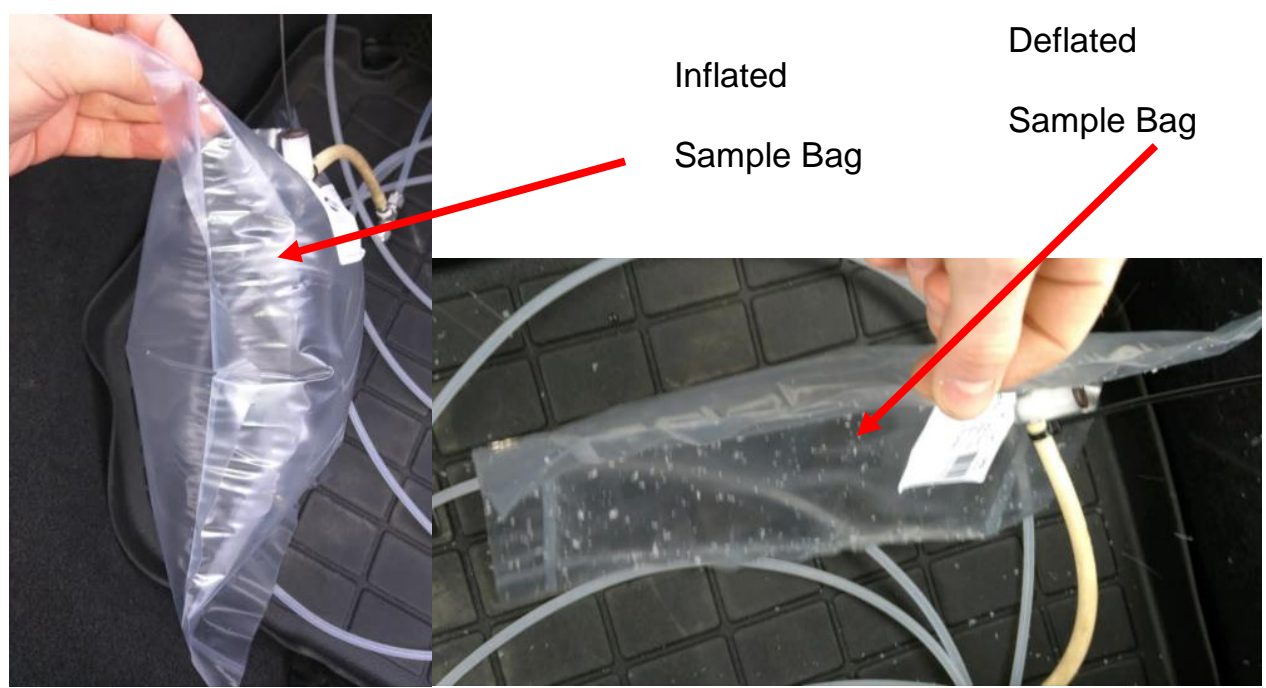

Figure 42 Left: Inflated Bag. Right: Deflated Bag

It can be inferred that the flow rates seen from the ESS during charging is due to the self-heating of the li-ion batteries that occur during chemical changes. Chemical changes occur when there is an imbalance in the battery during charging or discharging. The author in [24] observed the same behavior.

\subsection{Smoke Test Experiment}

\subsubsection{Smoke Test Setup}

After finding out that the ESS behaved as a heat pump during temperature changes, it was desired to see if gases could freely transfer between the ESS and the vehicle cabin. An experiment was set up to pump smoke into the battery pack of the BEV using the same manifold fabricated for sampling purposes. The first step was to prop open the one-way diaphragms on the battery pack vent to allow air to be forced into the pack. "C" Clips were fabricated to keep the diaphragms open, Figure 43, Figure 44. 


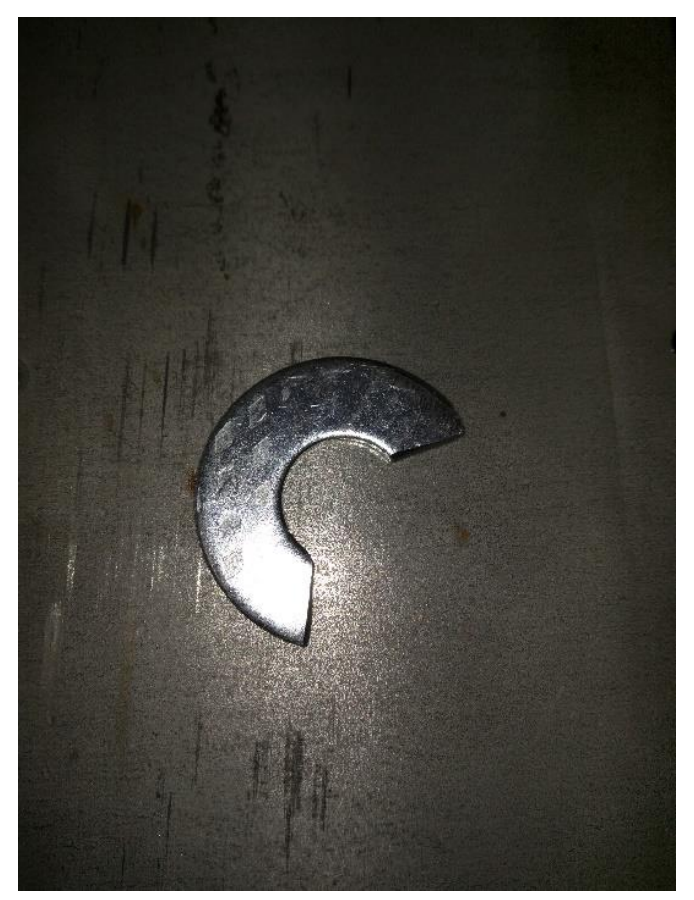

Figure 43 C Clips Were Fabricated to Hold the Orange Diaphragm Valves Open

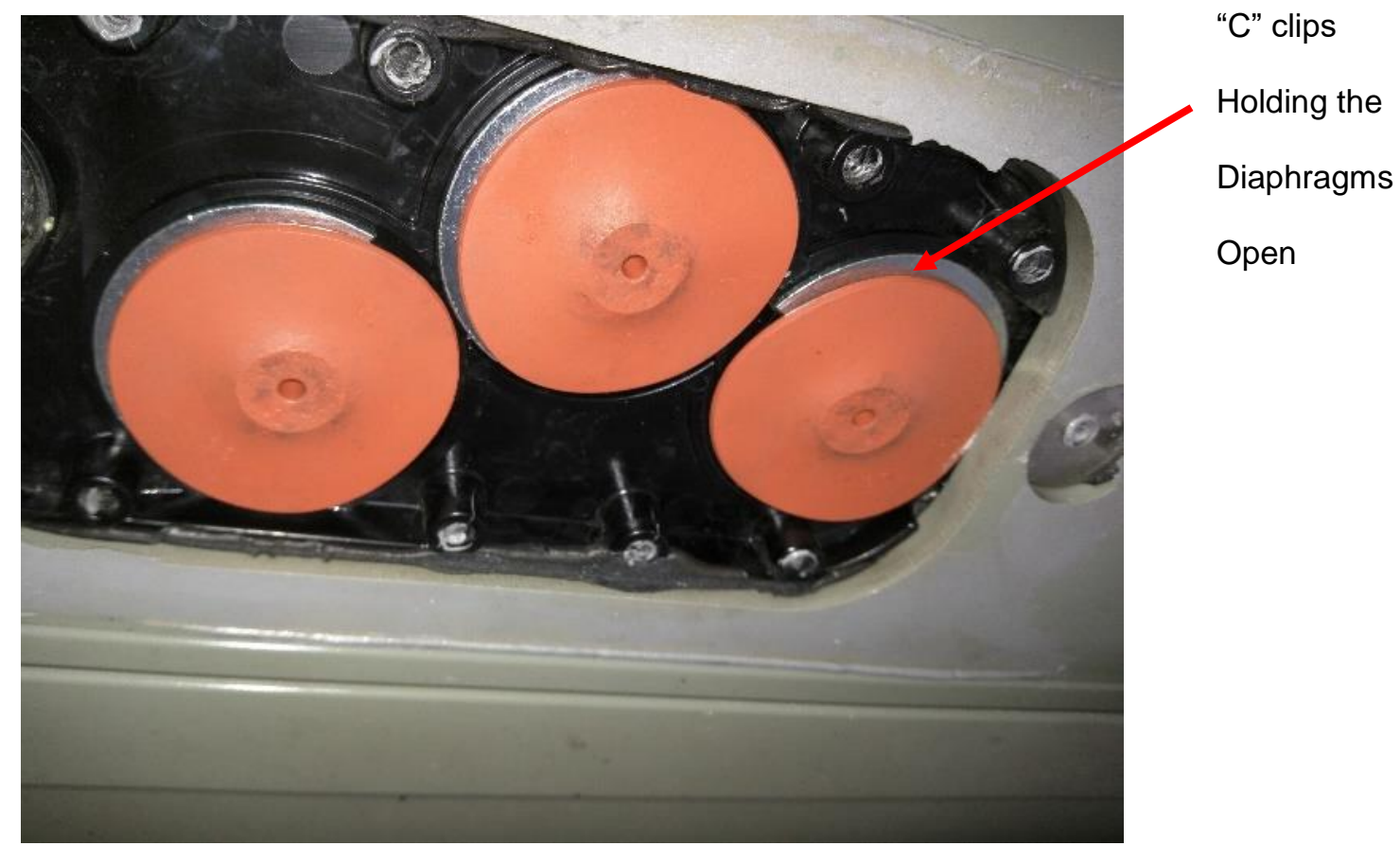

Figure 44 "C" Clips are Installed to Hold the Valves Open

The manifold box used for battery sampling was reinstalled over the open valves. A pressure gauge was installed to monitor the pressure of the ESS. An increase in pressure would mean that the pump was pressurizing the ESS and that no air was escaping. The manifold port had a barb fitting to 
transport smoke into the manifold, Figure 45. If the pressure gauge did not move it meant that the ESS was venting or exchanging gases with the cabin.

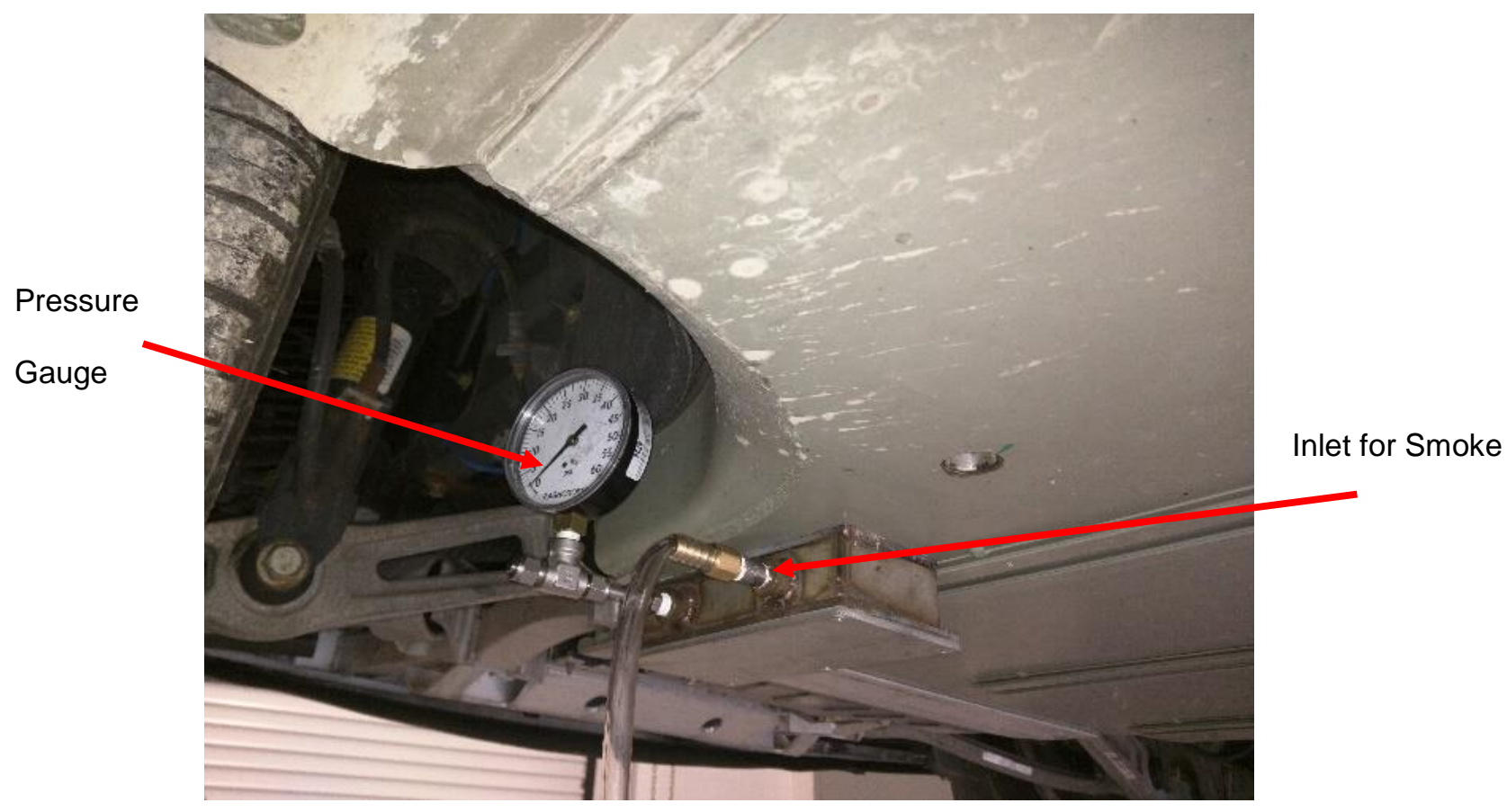

Figure 45 Manifold is Reinstalled with a Pressure Gauge to See if the Battery Pack Pressurizes

A cylindrical canister was fabricated to hold the smoke generator inside and funnel the volume of smoke to be transported by the pump, Figure 46. 


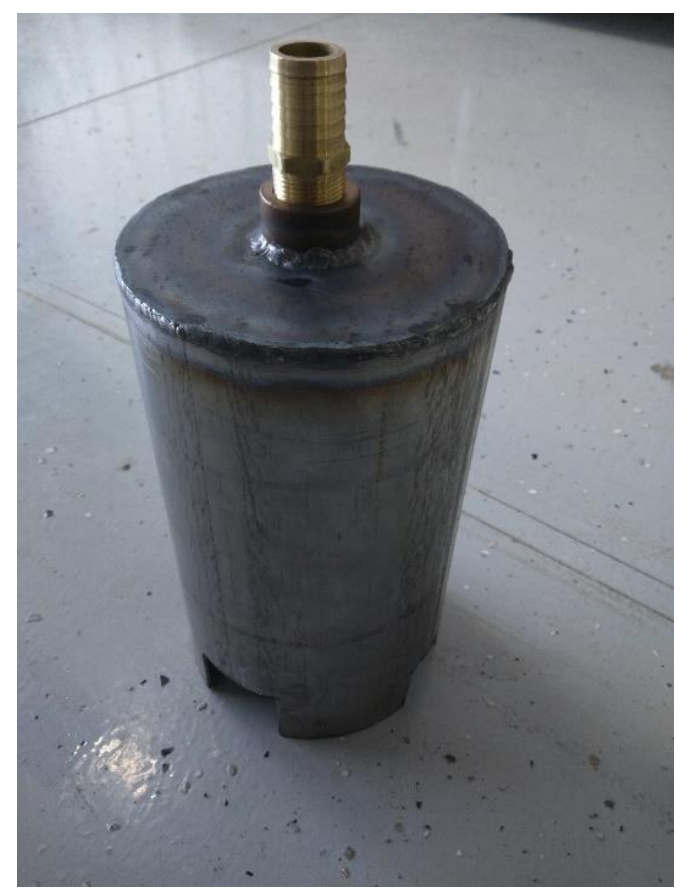

Figure 46 Canister to Funnel Smoke into the Manifold

A barb fitting with tubing going from the canister to the air pump was used to transport the smoke.

The style of smoke generator used is on top of the canister, Figure 47.

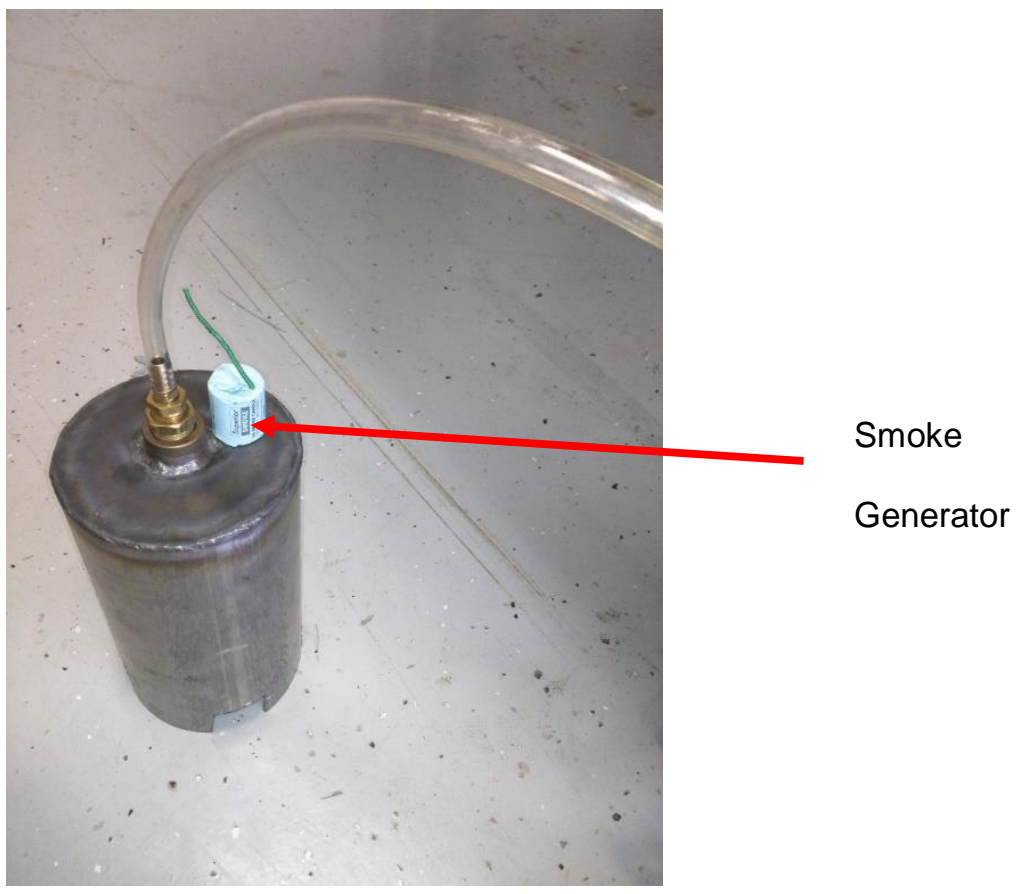

Figure 47 Canister with Tube and Smoke Generator 
The smoke canister was connected to the inlet of the pump, Figure 48. The outlet of the pump was connected to a Swagelok fitting, and tubing that transported the smoke to the sample manifold.

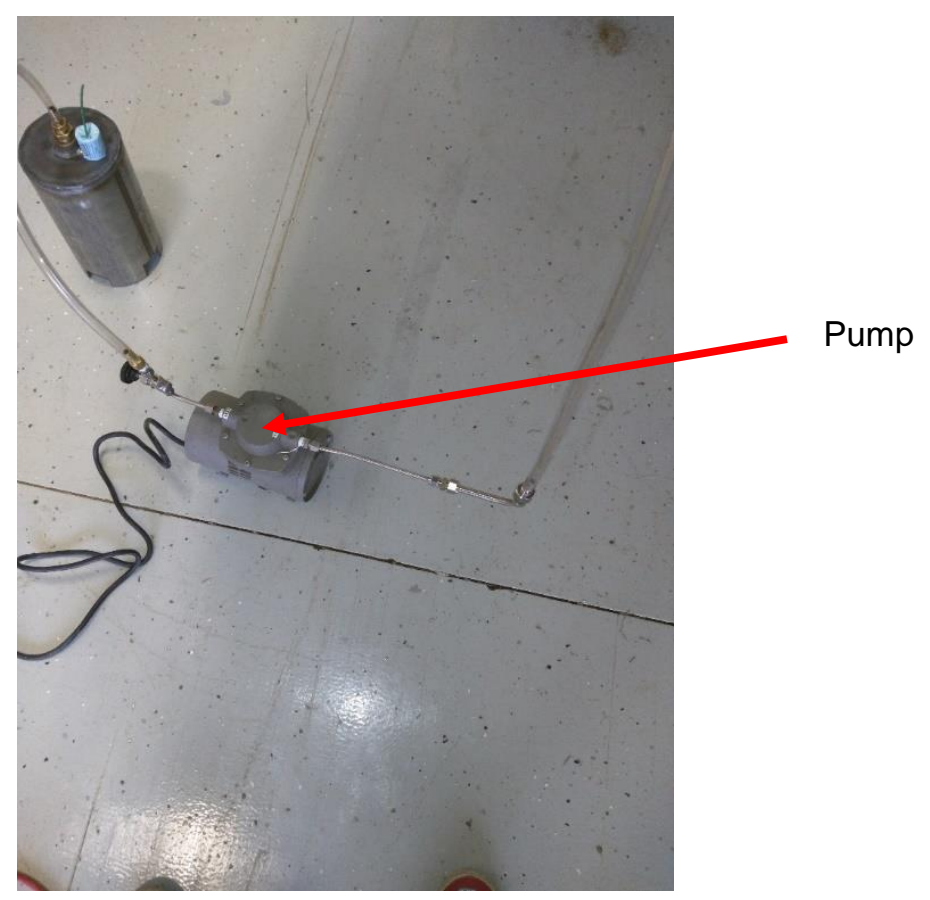

Figure 48 Smoke Canister Connected to the Pump

The canister was connected to the pump and the pump then the pump was connected to the sampling manifold, Figure 49. The smoke system allowed the ESS to be flooded with smoke. If smoke emitted from the pack anywhere the researchers could see from where it was emitting. 


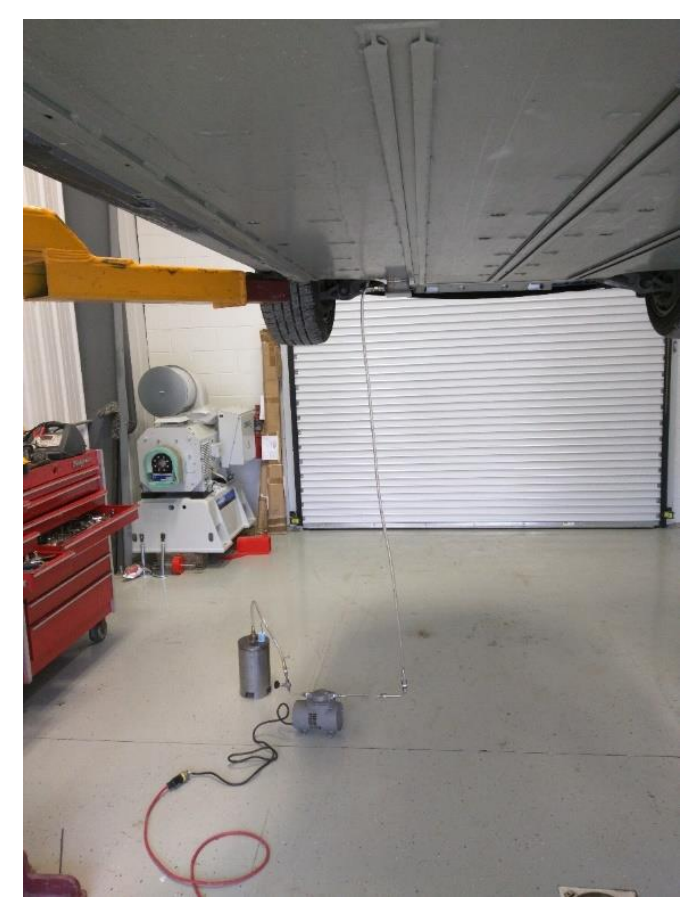

Figure 49 The Entire Smoke Generating System

\subsubsection{Smoke Test Results}

The smoke generator was lit and placed under the canister. The pump was turned on and smoke was forced into the ESS. The underside of the vehicle was observed, as well as the cabin of the vehicle. There were no visual signs that the smoke entered the vehicle cabin.

The purpose of the smoke test was to see if any potential emissions from the ESS could transfer into the cabin. Smoke was not observed in the cabin; however, another testing method was developed to overcome the flaws with this method.

\subsection{Carbon Dioxide Experiment}

\subsubsection{Carbon Dioxide Setup}

The smoke test showed no signs that anything had transferred into the cabin of the vehicle. The vehicle was taken outside and a new experiment was setup. A gaseous welding mixture of seventy-five percent Argon and twenty-five percent $\mathrm{CO}_{2}$ was used as a $\mathrm{CO}_{2}$ source, Figure 50. The $\mathrm{CO}_{2}$ bottle was used to pressurize the intake manifold, and in turn the battery pack.

$\mathrm{A} \mathrm{CO}_{2}$ analyzer was placed on the rear seat of the vehicle, which was approximately in the center of the vehicle cabin. The analyzer was left to run for half an hour to capture ambient $\mathrm{CO}_{2}$ readings in the 
vehicle cabin before the welding bottle was opened. A rise in $\mathrm{CO}_{2}$ detected by the analyzer would indicate that it was possible for the ESS and the cabin to exchange air.

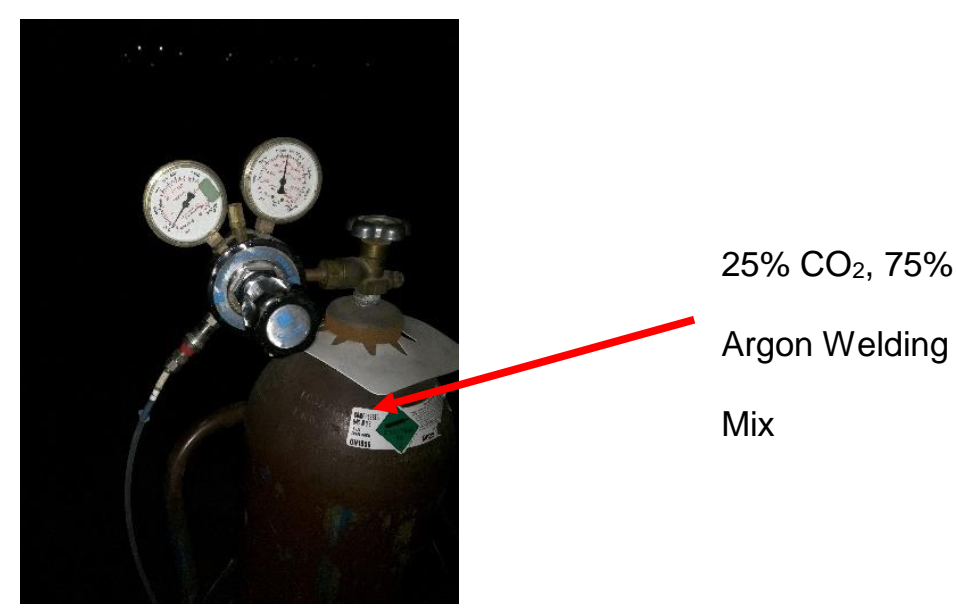

Figure 50: The $\mathrm{CO}_{2}$ Welding Gas Mix Used to Detect Presence of $\mathrm{CO}_{2}$

The analyzer used was a Horiba BE150, which is a non-dispersed infrared (NDIR) gas analyzer. The analyzer was placed inside the cabin of the vehicle, with a sampling pump to continuously draw air through the Horiba, Figure 51.

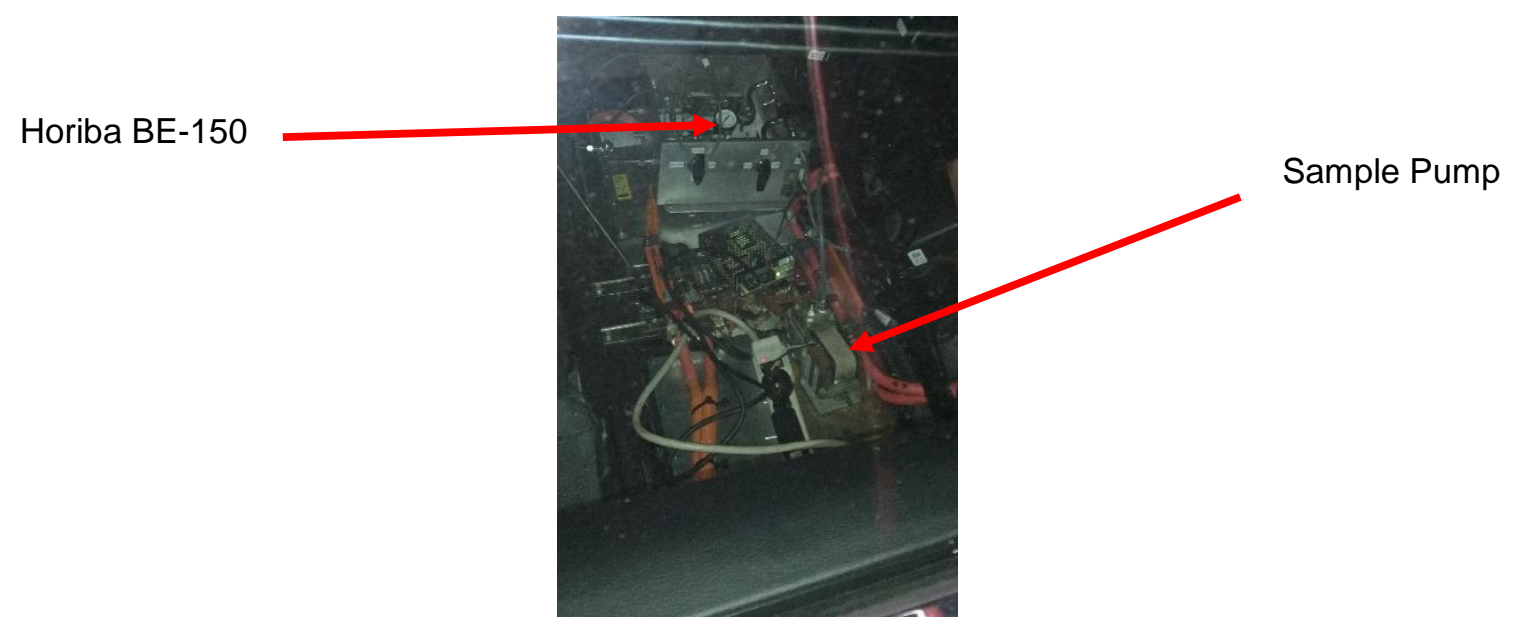

Figure 51: The DAQ Setup as well as the Box Containing the HoribaBE150

\subsubsection{Carbon Dioxide Results}

The bottle valve was opened and the gas mix flowed into the battery pack. After an hour of running this test the Horiba did not show any detection of $\mathrm{CO}_{2}$ outside of the ambient conditions. Since 
there was not a spike in $\mathrm{CO}_{2}$ during the experiment this showed that there is no direct pathway between the vehicle and the cabin.

\section{Bench Top Testing Procedure of BEV cells}

\subsection{Single Cell Design}

\subsubsection{Single Cell Setup}

The previous experiments all involved sampling the ESS as a whole. The individual battery cells were not isolated due to ESS construction. Several Tesla battery cells were purchased to test them individually, outside of the ESS environment. This would rule out if the FTIR results were influenced by construction materials used in the ESS, or if the batteries themselves were emitting. Isolating the battery cells outside of the ESS omits erroneous results produced by battery pack components. The chemistry and characteristics of the battery are proprietary data of Tesla, and not publicly disclosed. The closest battery to the Tesla, of similar composition, is the Panasonic NCR18650b. The specs for the NCR18650b can be found in, Appendix A.

The specification sheet states that charging must occur at $0.5 \mathrm{C}$ max, and $4.2 \mathrm{~V}$. " $\mathrm{C}$ " stands for coulombs, or the amount of charge that the batteries possess. The C-rate of a battery is directly related to the capacity of the battery. This calculation refers back to Equation 1 [21]. The purchased Tesla battery cells had a capacity of $3200 \mathrm{mAh}$ or 3.2Ah. For example, a battery with a capacity of 3.2Ah charging at $3.2 \mathrm{~A}$, for one hour, is charging at $1 \mathrm{C}$. As previously stated the battery cells should charge at $0.5 \mathrm{C}$ which means that they will charge at $1.6 \mathrm{~A}$, for two hours. The C-rates for charge and discharge times are shown in Table 6.

Table 6 Shows the C-rates for a Panasonic NCR18650b battery

cell.

\begin{tabular}{|l|l|l|}
\hline C-Rate Charge/Discharge & Time & Amps \\
\hline $2 \mathrm{C}$ & $30 \mathrm{~min}$ & $6.4 \mathrm{~A}$ \\
\hline $1 \mathrm{C}$ & 1 hour & $3.2 \mathrm{~A}$ \\
\hline $\mathrm{C} / 2$ & 2 hours & $1.6 \mathrm{~A}$ \\
\hline
\end{tabular}


The nominal voltage of the battery is $3.6 \mathrm{~V}$. To discharge the battery at different C-rates, resistive loads will need to be calculated.

$$
P=I * V
$$

Equation 8 Calculated Electrical Power

Where:

$\mathrm{P}=$ power (Watts)

$\mathrm{I}=$ current (Amperes)

$\mathrm{V}=$ Voltage $($ Volts $)$

As well as Ohms Law

$$
V=I * R
$$

Equation 9 Ohm's Law

Where:

$\mathrm{V}$, and $\mathrm{I}$ are the same as above

$\mathrm{R}=$ resistance(Ohms)

Table 7, below calculates the resistance needed, and the power needed to dissipate a $1 \mathrm{C}$ and $2 \mathrm{C}$ charge.

Table 7 Resistive Load and Power Dissipation Needed to Discharge at Specified C-rates

\begin{tabular}{|l|l|}
\hline $\mathbf{1 C}$ & $\mathbf{2 C}$ \\
\hline $3.6 \mathrm{~V} * 3.2 \mathrm{~A}=11.52 \mathrm{~W}$ & $3.6 \mathrm{~V} * 6.4 \mathrm{~A}=23.04 \mathrm{~W}$ \\
\hline $3.6 \mathrm{~V} / 3.2 \mathrm{~A}=1.125 \Omega$ & $3.6 / 6.4=0.5625 \Omega$ \\
\hline
\end{tabular}

To discharge the battery at $1 \mathrm{C}$ a resistive load of $1.125 \Omega$ capable of handling $12 \mathrm{~W}$ is needed. To

discharge the battery at $2 \mathrm{C}$ a resistive load of $0.5625 \Omega$ capable of handling $23 \mathrm{~W}$ of power is needed.

The battery cell was kept in an enclosure made from corrugated plastic. A window was made from clear acrylic to view the experiment. Wires were soldered to the battery cell and fed through a hole in the enclosure, allowing the charging, and resistive load to be placed on the battery. A Swagelok bulkhead was bolted through the side of the enclosure. A tube was connected to the bulkhead so that a sample bag could be filled during charging and discharging. All edges and holes were sealed with hot glue. 
If the experiment took place at a constant temperature, Charles' Law of ideal gas expansion due to temperature change, would not have any effect. Figure 52, and Figure 53 show a computer aided design (CAD) model of the experiment.

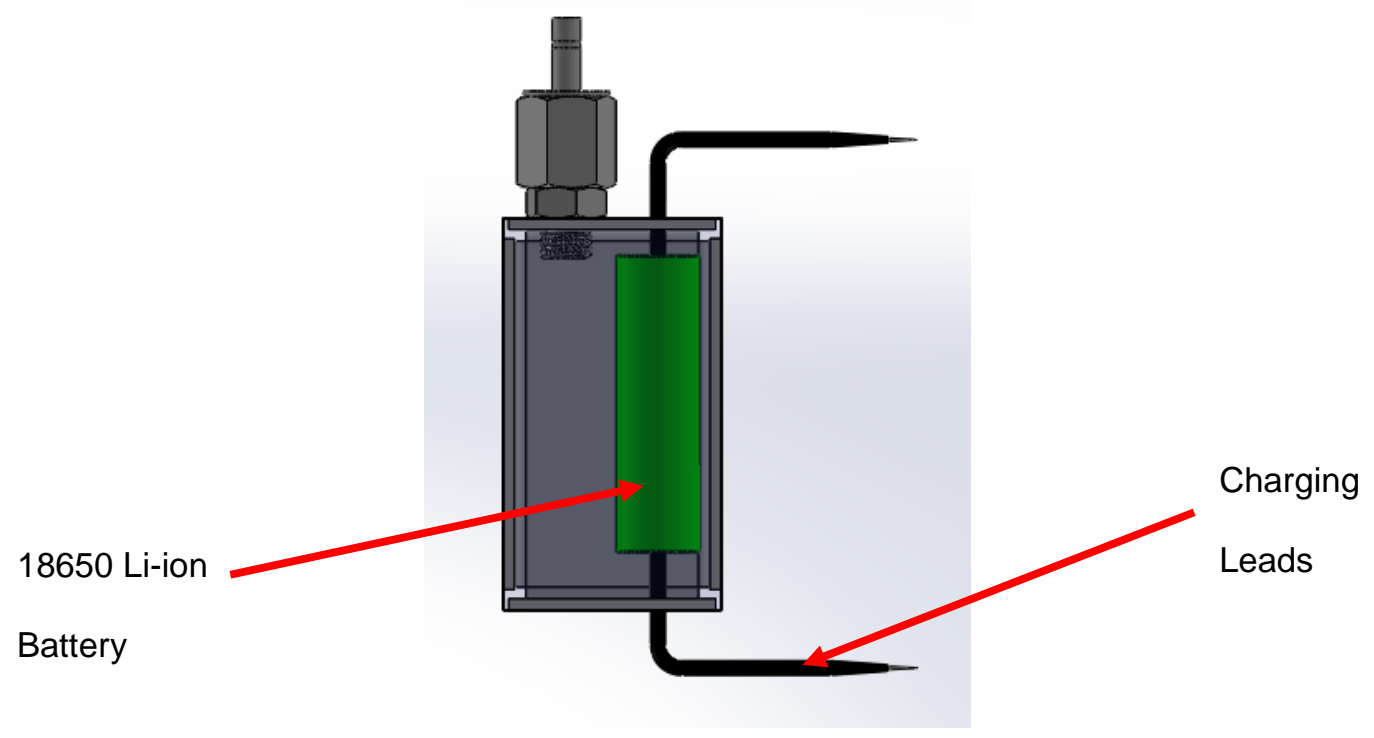

Figure 52 Top View of Enclosure Looking into the Test Chamber

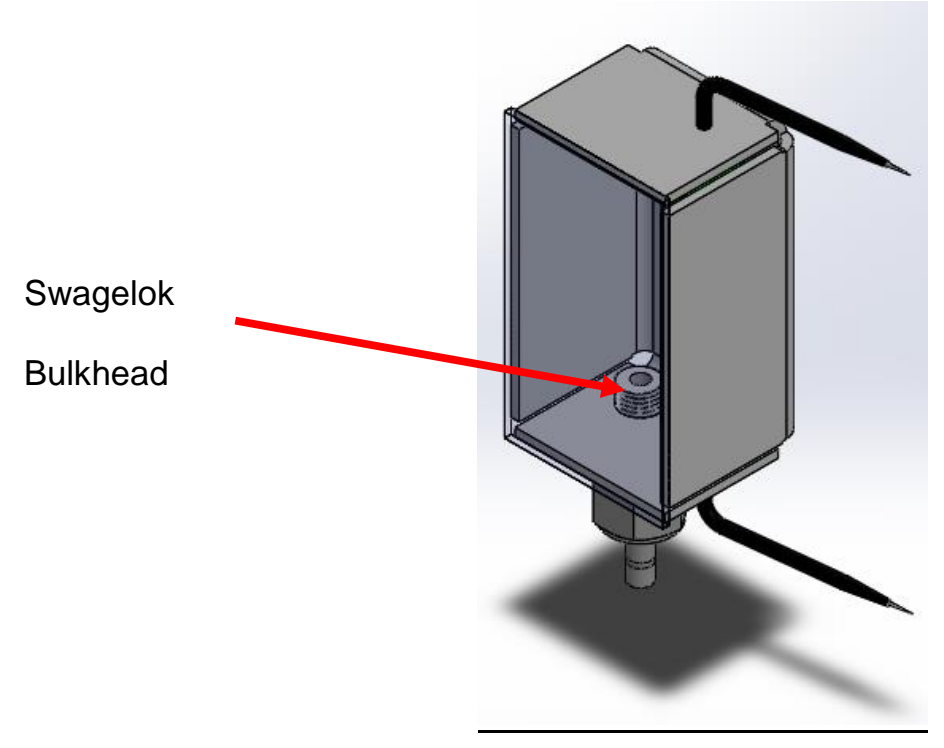

Figure 53 Isometric View Looking Through Acrylic

\subsubsection{Single Cell Testing}

The discharge circuits are seen below in Figure 54 . The circuits were created using $1 \Omega, 5 \mathrm{~W}$ resistive heaters, placed on a breadboard. 


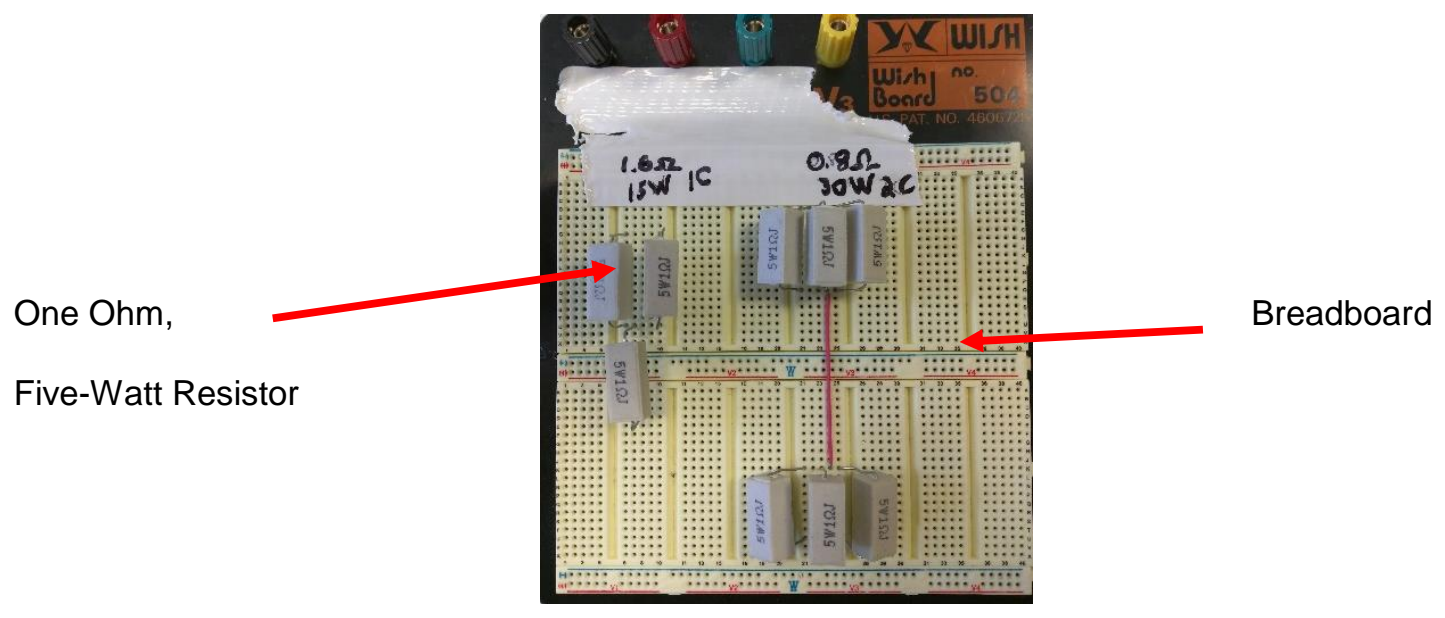

Figure 54 Resistive Circuit Used to Discharge at 1C and 2C

Prior to charging or discharging the battery, the sample bag was opened to allow pressure to equalize between the sample chamber and the bag. Figure 55, shows the single cell test setup. The battery cell is isolated in the fabricated enclosure, connected only to the sample bag.
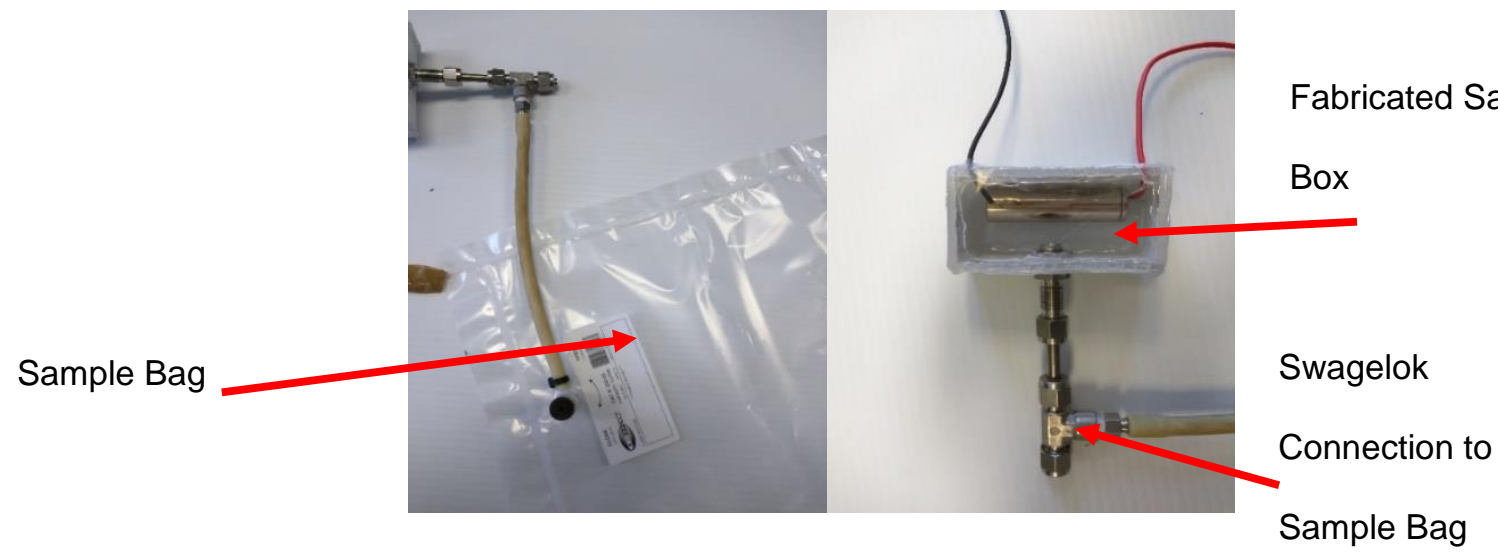

Figure 55 Left: The Sample Bag Connected to the Bulkhead.

Right: The Single Battery Cell Enclosed.

Figure 56 shows an overview of the single cell testing setup. The isolated cell is in the enclosure, connected to the Tedlar® sample bag. The leads used for charging and discharging pass through the side of the enclosure, and are sealed. 


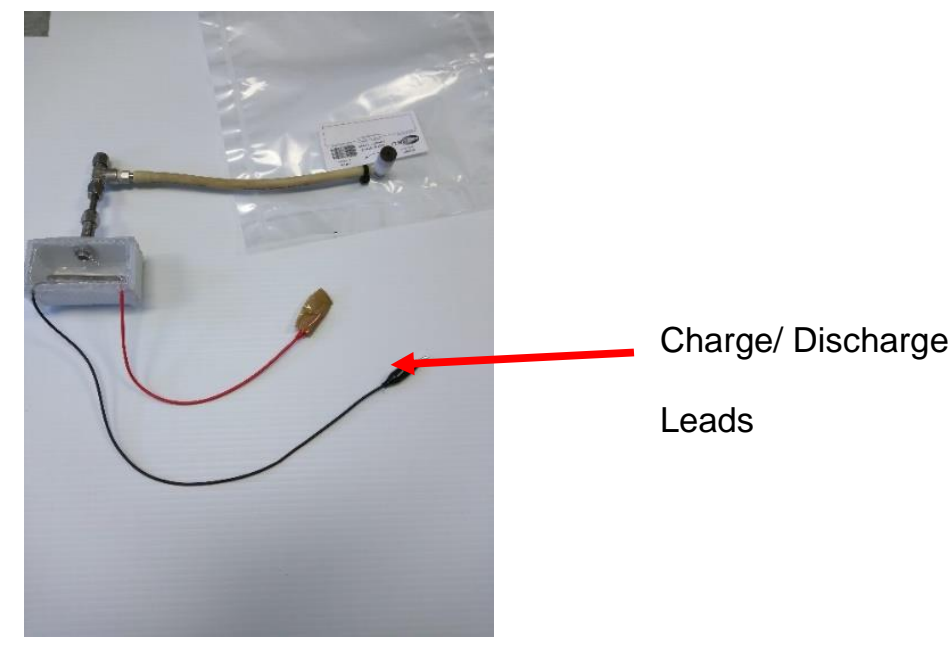

Figure 56 The Single Cell Sample Test

The battery was discharged across a resistive circuit of $1.6 \Omega$ calculated. Due to variability in each resistor the measured resistance of the circuit was $1.8 \Omega$. The measured current draw on the battery was 1.5A. The current was drawn from the battery until the OCV of the battery was $2 \mathrm{~V}$. This is below the minimum voltage for a single cell, based on Appendix A.

The battery cell was then connected to a power supply to recharge. The power supply was set at 4.2V and current limited to $1.63 \mathrm{~A}$ as recommended in Appendix A. After charging for an hour the battery was connected to a single $1 \Omega$ resistor. This draws a current from the battery directly related to the resistance, 4A. The sample bag showed no signs of inflation even after the more aggressive discharge. It was not expected that the battery would produce gases following the specification sheet recommendations.

After depleting the battery cell to $2 \mathrm{~V}$ the battery was recharged using the power supply. This time power supply was set to $12 \mathrm{~V}$ and current limited to $4 \mathrm{~A}$. After five minutes of charging the current was raised briefly to $6 \mathrm{~A}$. This is a charge rate 3.6 times the recommended charge rate. The battery remained cool and the sample bag showed no signs of inflation.

The single cell setup showed no signs of gaseous expansion or self-heating. The next experiment included multiple cells in an array of two battery cells in parallel, and three of these modules in series. This should give a discharge rate of $10 \mathrm{~A}$ across a $1 \Omega$ resistor. 


\subsection{Multiple Cells Testing}

\subsubsection{Multiple Cells Setup}

The series parallel configuration seen in Figure 57 produced a voltage of $11.6 \mathrm{~V}$. The pack setup had a new capacity of $6.4 \mathrm{Ah}$. This allowed the pack to discharge at a higher current for a longer period of time.

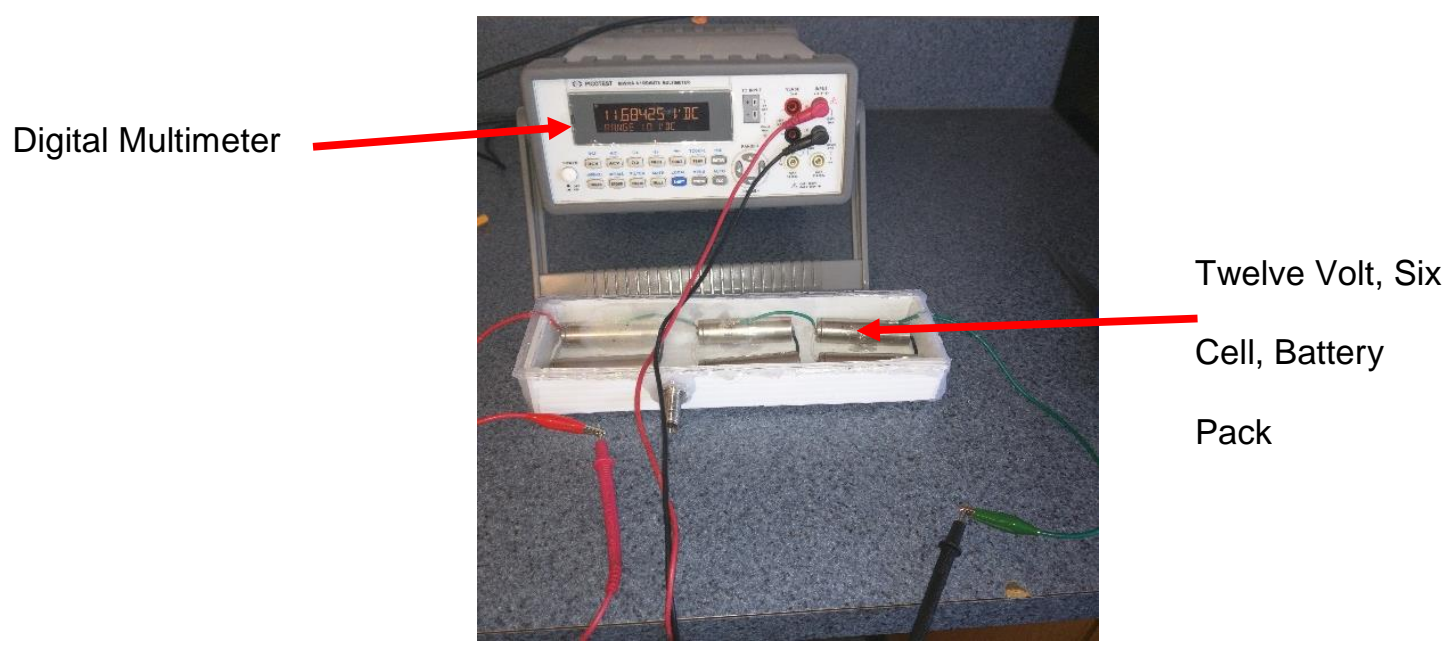

Figure 57 Digital Multi Meter Measuring the Voltage of the New Battery Configuration

The resistive circuit seen in Figure 58 had a resistance of $3.3 \Omega$ and was capable of dissipating $50 \mathrm{~W}$ of heat. The circuit allowed for a current flow of 3.5A.

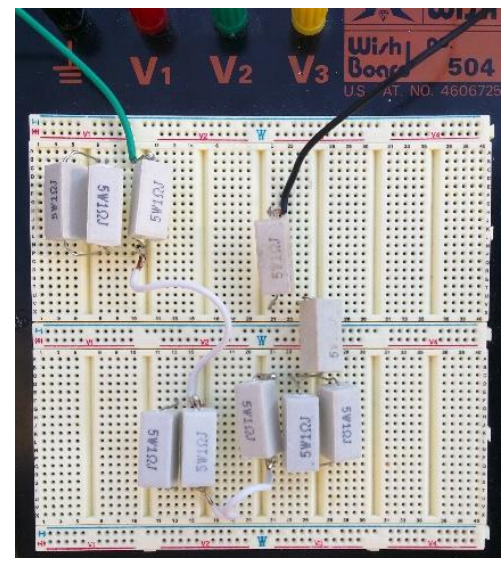

Figure 58 Resistive Network Used to Discharge the Battery Pack 


\subsubsection{Multi Cell Results}

While the battery pack was discharged the sample bag was connected to the sealed battery pack, Figure 59. The battery pack was left to discharge for forty minutes. After the forty-minute timeframe the bag showed no sign of inflation. After the forty minutes of discharge, the battery pack was connected across a single one-ohm resistor. This created a current draw of ten amps for a short duration, until the resistor failed. After the aggressive discharge, the bag did not inflate.

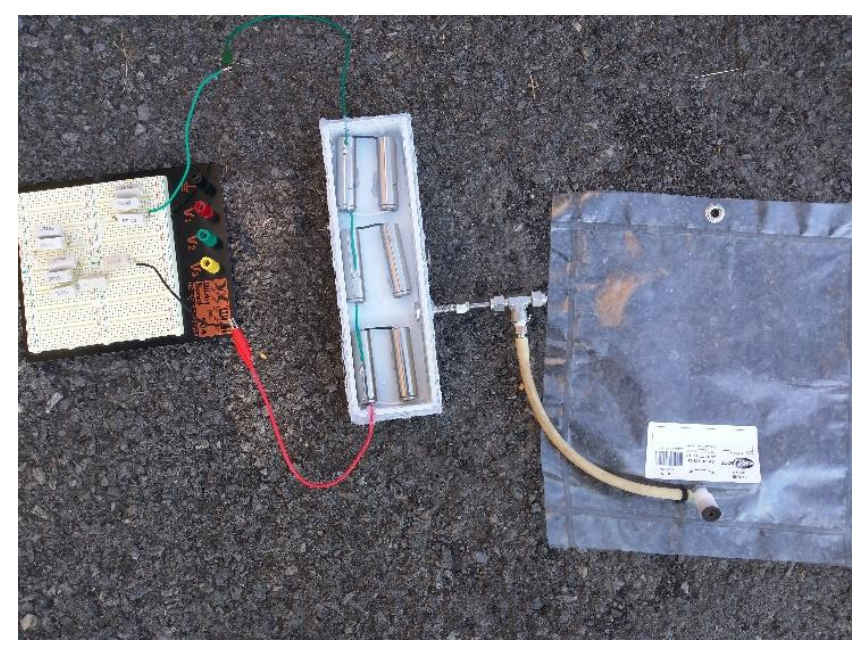

Figure 59 The Battery Pack Discharging While Connected to a Sample Bag

The next experiment was to drill a small hole in the sampling box to allow a sample pump to draw air through the box slowly. The sampling pump was connected to the Swagelok outlet creating an air flow through the box, over the battery cells in an effort to mimic previous testing with the ESS on the vehicle.

\subsection{FTIR Analysis of Multi-Cell Emissions}

The batteries showed no signs of off gassing during the passive tests (i.e. bag did not inflate from thermal expansion or the battery cell producing gases). For the last test, a small hole was drilled into the sample box, Figure 60. A variable flow sampling pump was attached to the Swagelok, allowing a flow across the batteries to occur. The outlet of the pump was connected to a ten-liter sample bag. The pump was set to one Ipm, giving a total sample time of ten minutes per bag. 


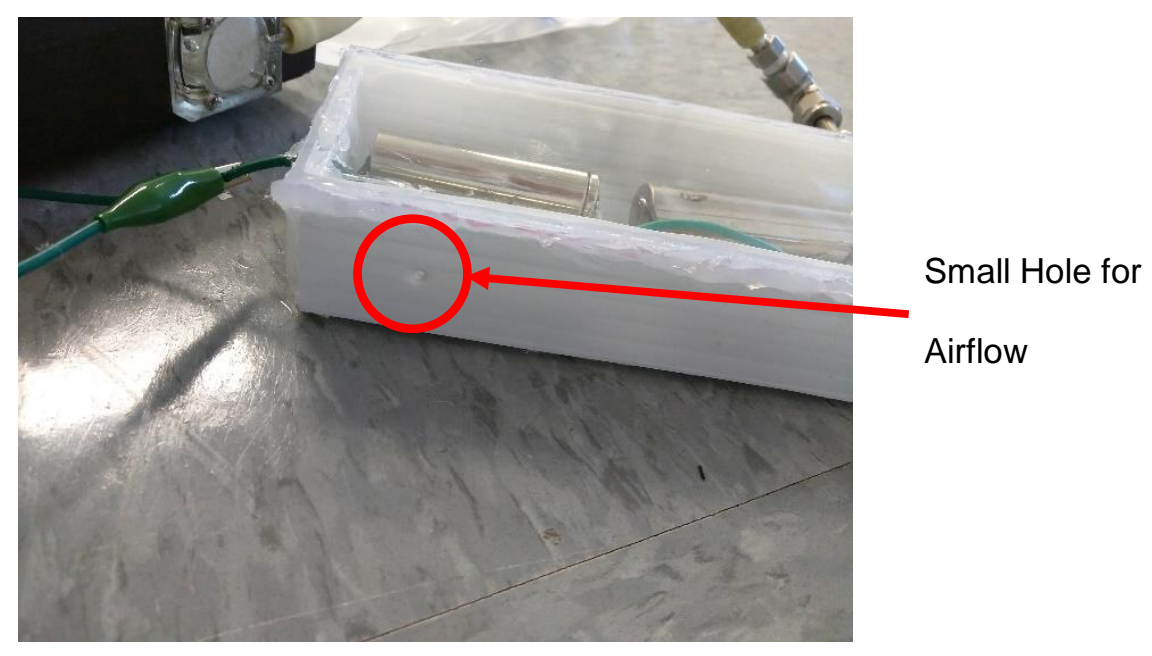

Figure 60 Small Drilled Hole Circled in Red.

The first sample bag was taken across the batteries without any charging or discharging occurring. This was the control bag to sample anything that might be present in the plastic sampling housing, Figure 61.

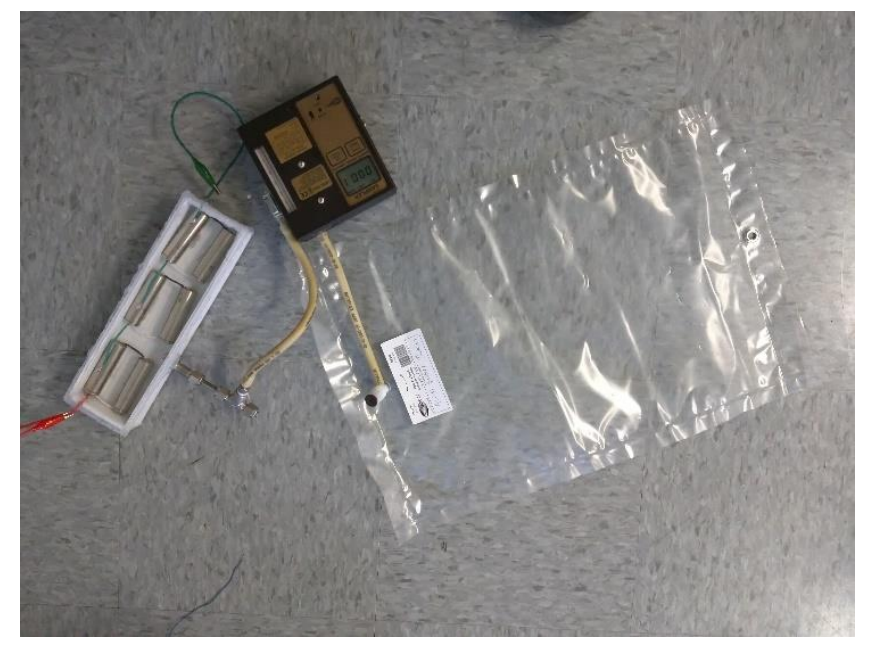

Figure 61 No Load is Placed on the Batteries. Sample is Taken as Control

After a new sample bag was connected, the experiment was repeated while rapidly charging and discharging the battery pack. Figure 62 shows the setup where the charging took place. Figure 63 , shows that the battery pack was charged at $9.5 \mathrm{~V}$ and five amps. 


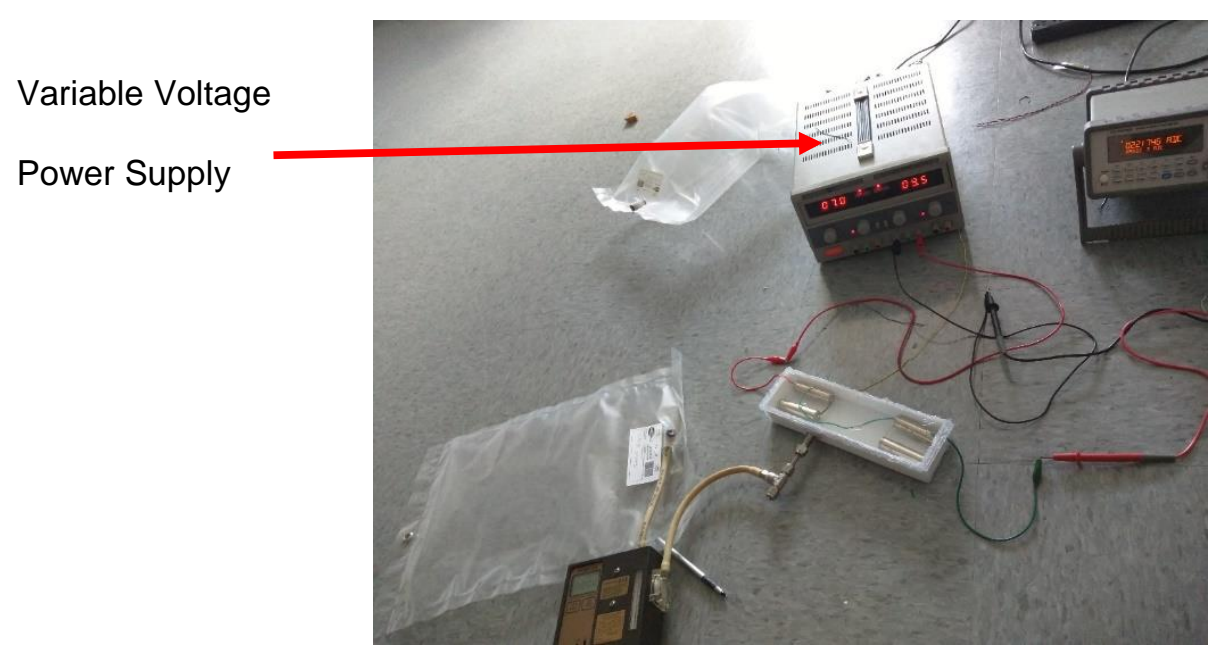

Figure 62 The Charging Circuit

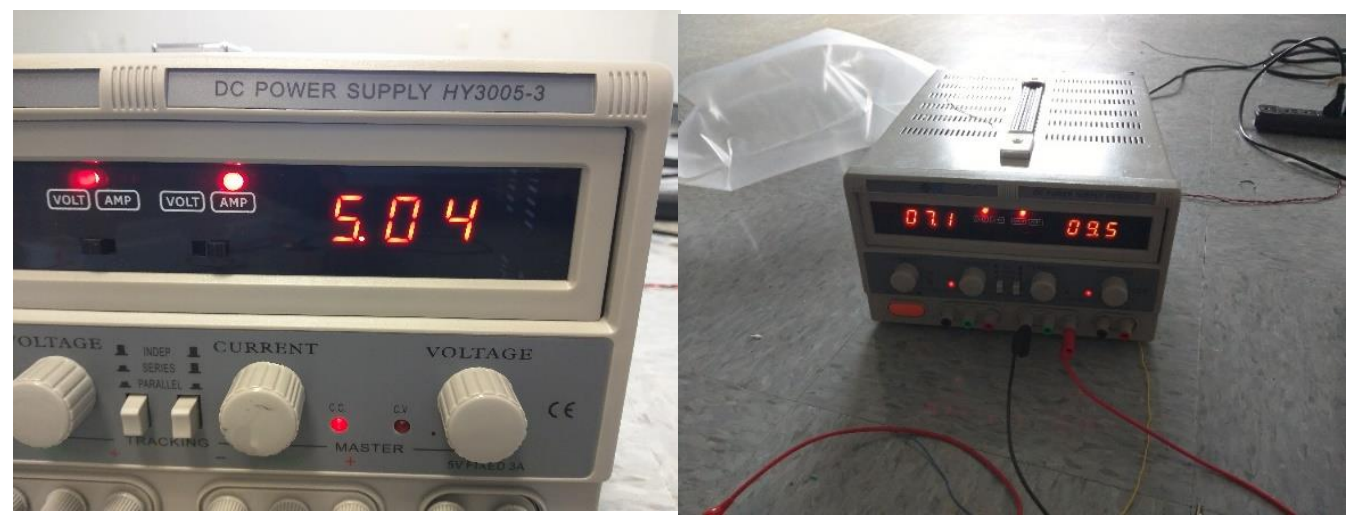

Figure 63 Shows the Power Supply Charging at 9.5V and 5A

The batteries were discharged across a resistive circuit of $1.2 \Omega$, at $6 \mathrm{~A}$, Figure 64 . 


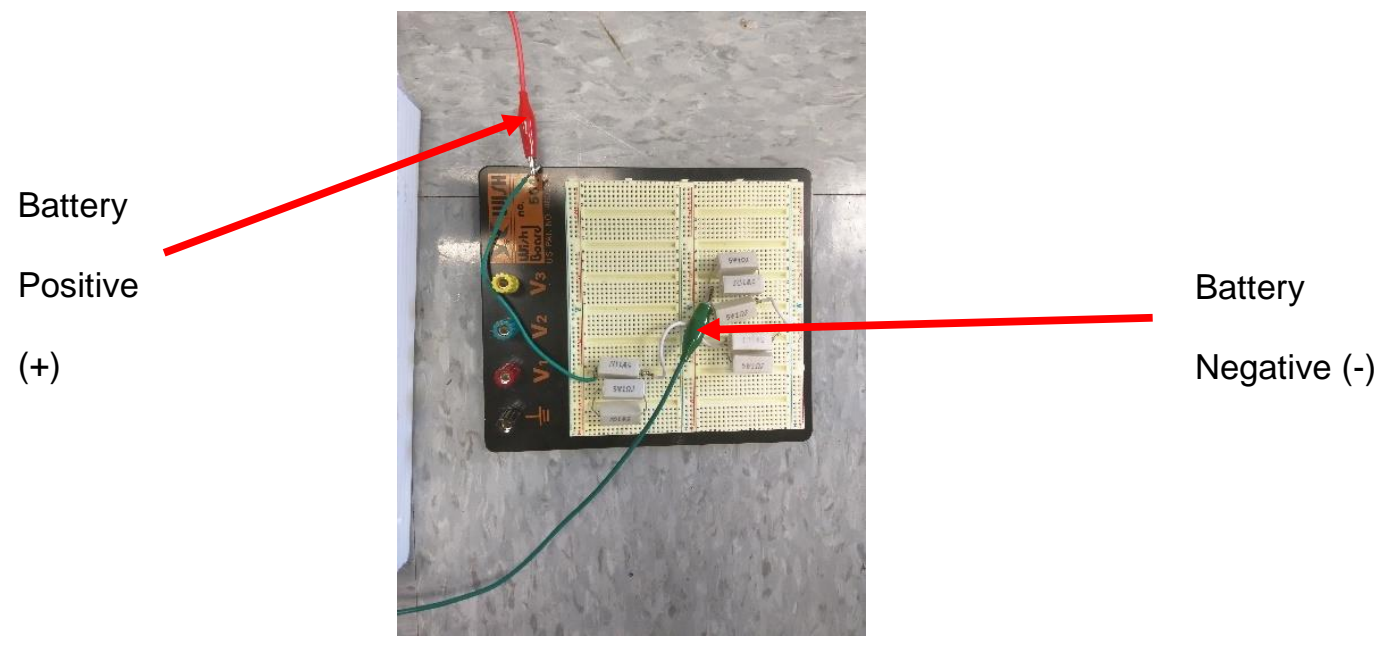

Figure 64 The Circuit Used to Discharge the Batteries.

There were five charge cycles and five discharge cycles during the ten-minute sampling period. Every minute the leads were switched between charging as in Figure 62, to discharging as in Figure 64. The goal was to stress the multiple test cells with rapid charging and discharging. The control bag and the sample bag were analyzed by the FTIR.

After running the sample bags through the FTIR no discernable results were found between the control and the sample. Ethane was the only compound recorded from the FTIR results. The goal was to compare the ethane data from the benchtop testing to the ethane results SwRI detected from the ESS. Figure 65 shows the FTIR results from the benchtop testing of the battery cells. No discernable differences were observed between the control and the sample. The elevated ethane concentrations SwRI detected must have been due to construction materials in the battery pack, or perhaps damaged battery cells in the ESS. If the batteries emitted ethane, the benchtop test would have indicated its presence. 


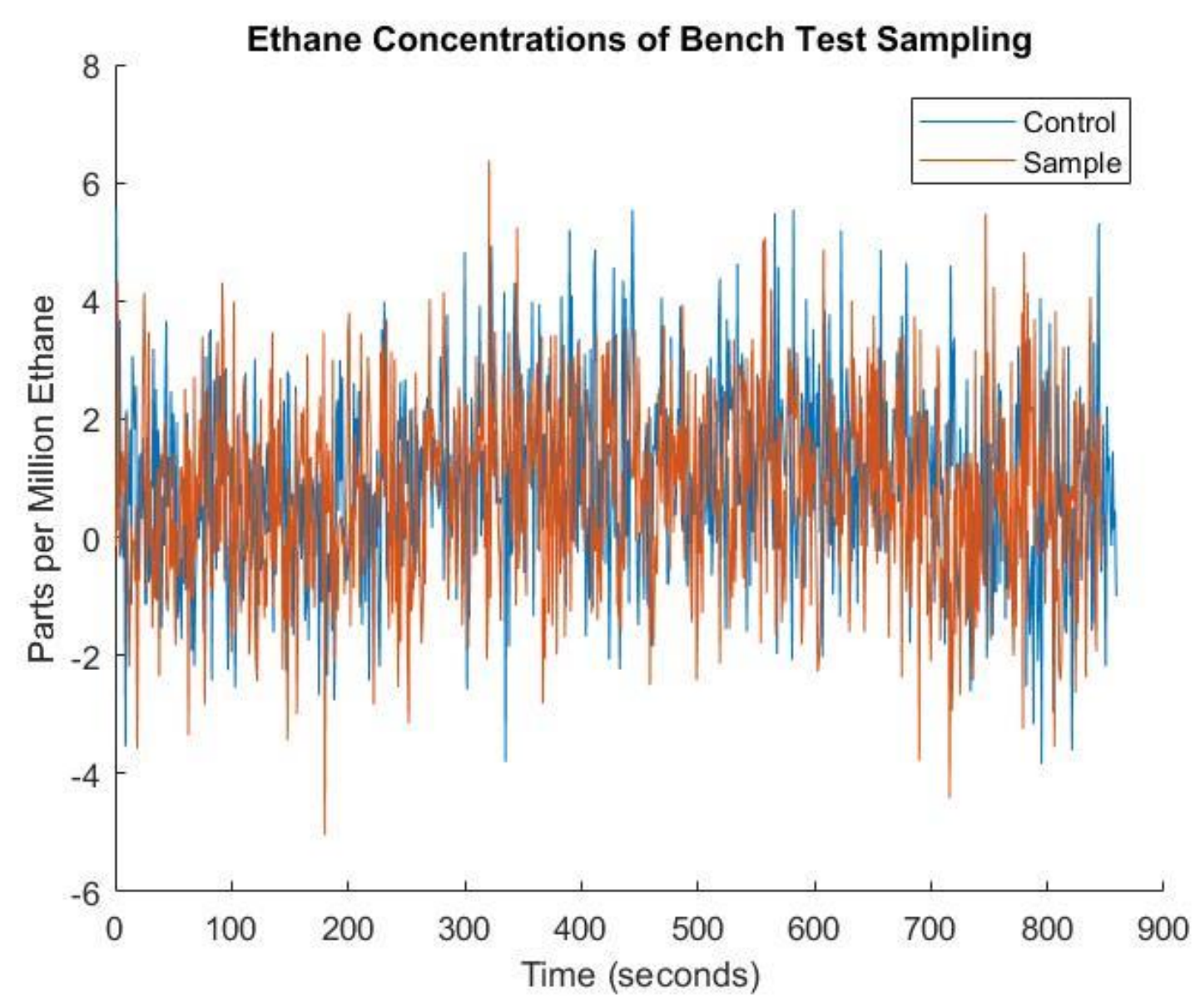

Figure 65 Shows No Discernable Differences Between the Control and the Sample

\subsection{Measuring Cell Temperature with a Thermocouple}

Lastly the cell temperature was measured during charging and discharging. A type $\mathrm{K}$ thermocouple was inserted into the hole drilled in the previous step. The type $\mathrm{K}$ thermocouple measures temperatures from $-200^{\circ} \mathrm{C}$ to $1250^{\circ} \mathrm{C}$ with an accuracy error of $2.2^{\circ} \mathrm{C}$ [28]. The tip of the thermocouple contacted one of the four batteries, and the thermocouple was sealed in place. Figure 66 shows the thermocouple in contact with the battery cell. 


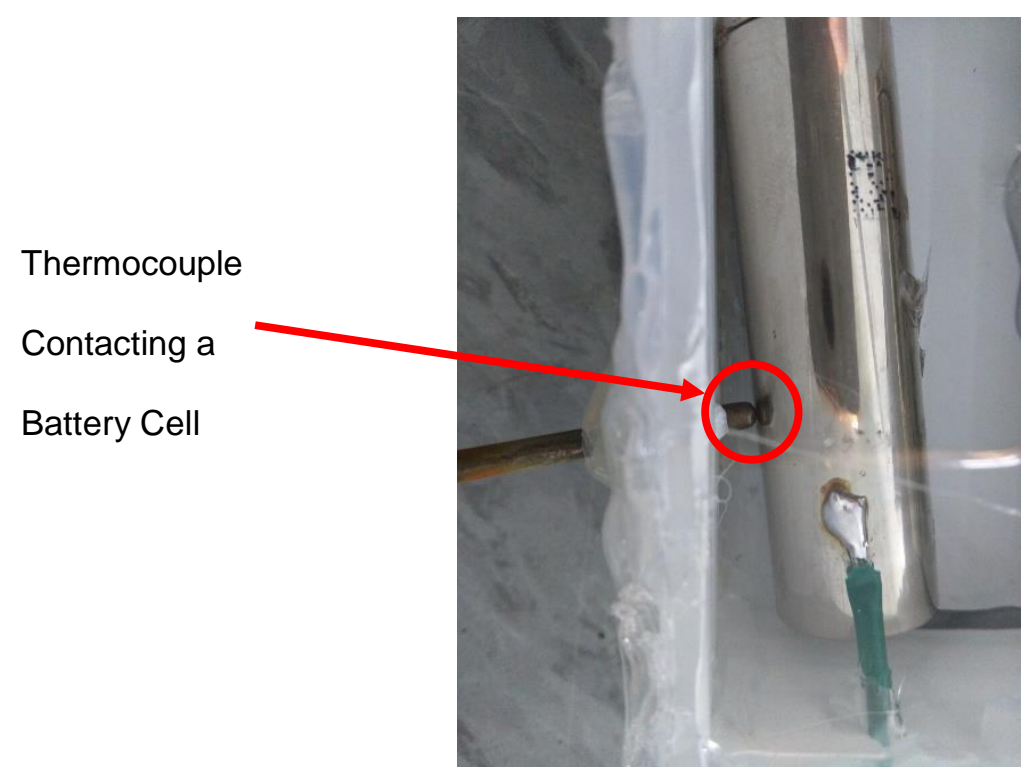

Figure 66 The Thermocouple is in Contact with the Battery Cell

Figure 67 shows the type $\mathrm{K}$ thermocouple used to measure the cell temperature.

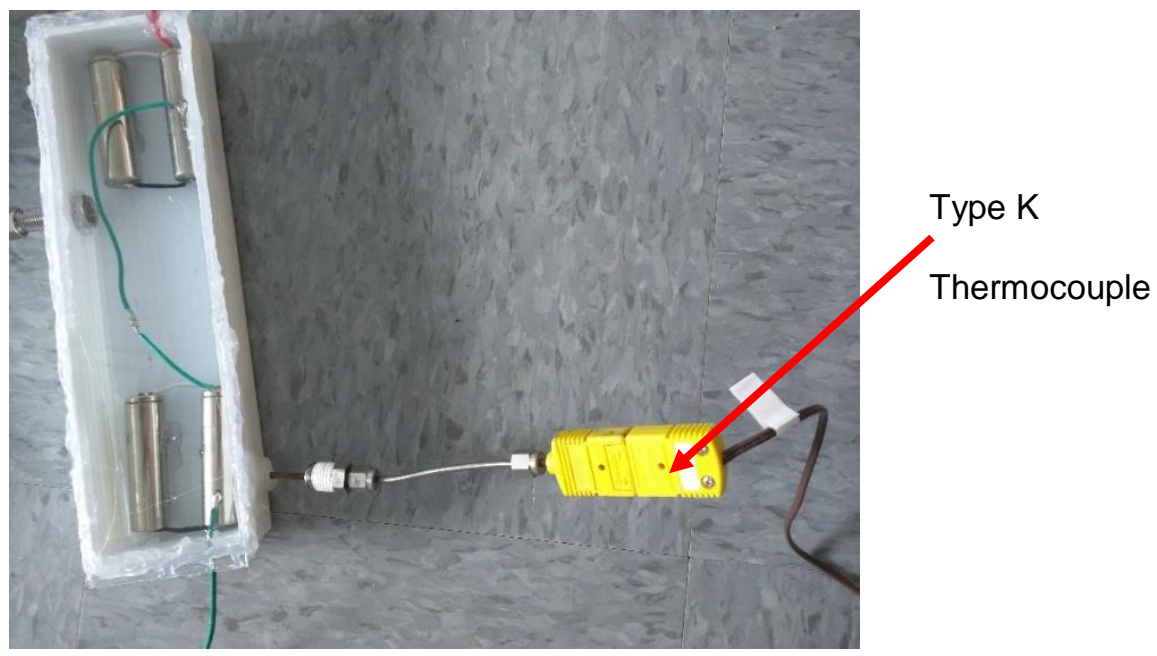

Figure 67 Type K Thermocouple Contacting the Battery Cell

The test was started after the batteries had sat at room temperature overnight. This ensured that the battery transients had settled and that the batteries were the same temperature as the ambient room air.

The test started at a room temperature of $24.2^{\circ} \mathrm{C}\left(75.5^{\circ} \mathrm{F}\right)$. The battery pack was first discharged across a $1.8 \Omega$ circuit, at $4 \mathrm{~A}$. The temperature rise was recorded until the battery pack hit an OCV of $6.5 \mathrm{~V}$. 
$6.5 \mathrm{~V}$ is the minimum allowable voltage for the battery pack until charging must occur as seen in Appendix A.

Figure 68 plots the temperature of the discharging battery over time until the cutoff minimum OCV of $6.5 \mathrm{~V}$ is reached.
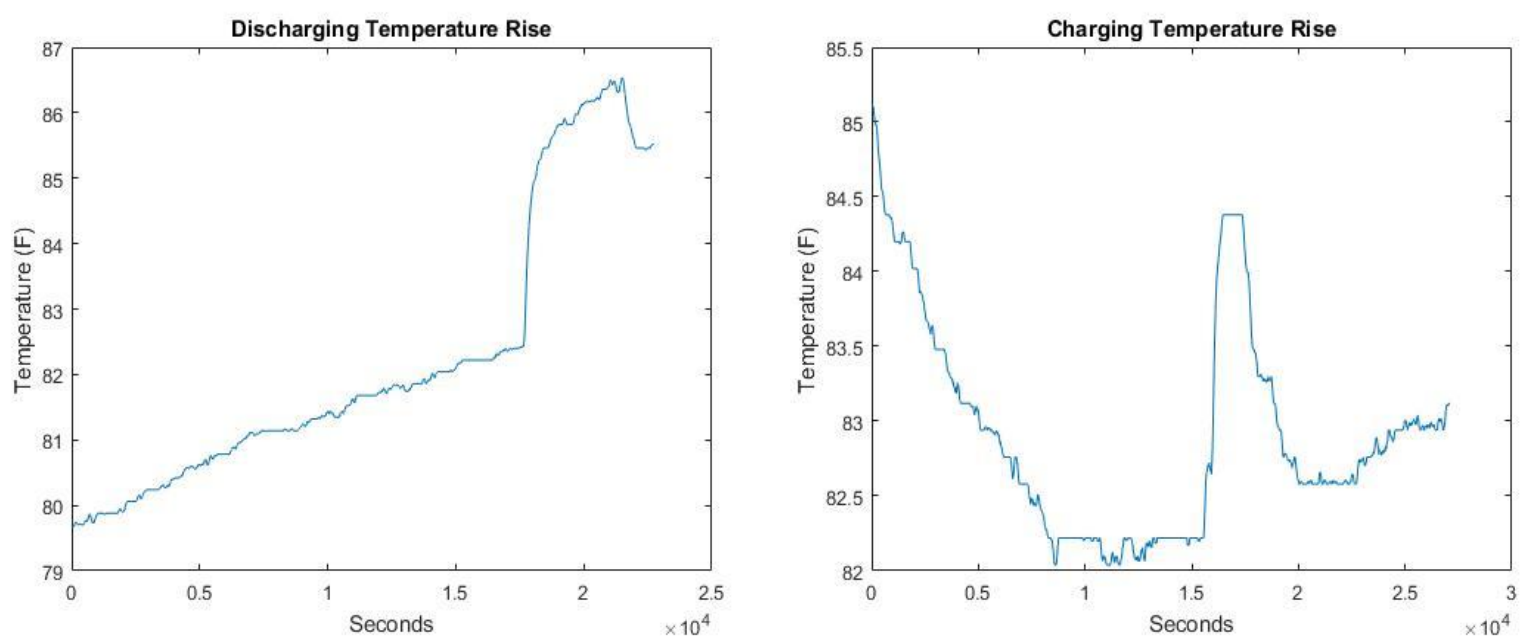

Figure 68 Left: Temperature Rise of a Battery Cell due to Discharge. Right: Temperature Rise of a Battery Cell due to Charge.

The maximum battery cell temperature was seen during the discharging cycle. The maximum temperature was $30.4^{\circ} \mathrm{C}\left(86.7^{\circ} \mathrm{F}\right)$. According to [24] this heat increase during charge and discharge is due to battery internal resistance. The thirty-degree Celsius/ max temperature is well below the eighty-degree Celsius temperature where the battery first starts to degrade due to overheating.

Charles' Law is an adaptation of the Ideal Gas Law. It assumes that a gas behaves ideally, and that the pressure of the system is kept constant.

The volume of air in the sampling box was calculated to be $0.37 \mathrm{~L}$. The final and initial temperatures are also known from the experiment. Using Charles' Law, Equation 7, the final volume of air is $0.46 \mathrm{~L}$. During the temperature rise of the battery cells during the experiment the gas expanded $0.9 \mathrm{~L}$. While this seems trivial at such a small volume of air, increasing the initial volume to $1 \mathrm{~L}$ and keeping the temperatures the same as above the final volume is $1.25 \mathrm{~L}$. Adjusting initial volume to $10 \mathrm{~L}$ gives a final volume of $12.6 \mathrm{~L}$. 
The BEV battery pack has a larger volume than calculated above. The BEV also underwent more aggressive charging and discharging than tested during the benchtop experiment. The sample bags that were filled during supercharging and driving are expanded gases due to temperature increase.

\section{Conclusions}

\subsection{Energy Consumption}

The energy consumption of the vehicle was similar to the manufacturer MPGge claims. The BEV performed better on the highway than it did during Morgantown City driving. This is because there were no current spikes associated with accelerations from a stop, which were commonly seen in the Morgantown route.

The models that the Tesla uses to predict range and specific energy consumption closely correlate to the data that was collected though on road testing and dynamometer testing. This affirms two things. The first being that the Tesla energy consumption calculations did not have artificially inflated results at an attempt to make the vehicle seem more energy efficient than it is. The second, being that the data recorded and processed from the on road and dynamometer testing were accurate.

\subsection{Battery Emissions}

The ESS did emit gases, however; the elevated ethane concentrations SwRI detected may have been produced from battery pack glue, plastics, or other construction materials. Whatever was produced during driving and supercharging could be from a substance in the battery packaging itself.

Another possibility would be that some of the battery cells themselves are damaged in the pack and are emitting substances that were picked up during analysis. A damaged, burning or heated battery can emit toxic vapors [29]. The vapors include sulfuric acid, carbon oxides, nickel, lithium, copper, and cobalt. This was not proven because the ESS is tightly sealed. The benchtop experiment did not consider damaged cells, all the cells were intact at the time of testing.

Both the sample bags and the ambient air bags from all emissions experiments were run through the same FTIR analyzer. This ensured that no erroneous results were displayed. If the FTIR was contaminated with hydrocarbons from other researchers, the same external errors would be recorded for 
the control and the samples. Although there were some elevations from certain hydrocarbons, the mass rate of gas out of the ESS is orders of magnitude lower than the tailpipe emissions of an ICE powered vehicle.

\subsection{Benchtop Testing}

The benchtop testing provided evidence that the batteries self-heat during charge and discharge cycles. It also indicated that any previous compounds observed during vehicle testing must have been from a damaged cell(s) or other materials used in the ESS. This study shows that any expansion received during charging or driving the BEV is due to a temperature rise and consequent gas expansion. The battery cells did not produce any emissions when they were isolated and tested. The inflation of the bags while charging or driving is due to the expansion of gases during a temperature rise of battery cells heating up.

\section{Recommendations}

Statistical software could be used to correlate ambient temperatures to the battery consumption. A correlation between cold air and battery performance could be developed. It was often noticed that the battery would lose charge when the ambient temperatures dropped below freezing. A warning would pop up on the Tesla console saying that the regenerative braking was disabled during extreme cold. This is due to changes in battery internal resistance, which is a function of temperature. The internal resistance rises as the battery gets colder, this makes it dangerous for the battery to accept current.

Another beneficial recommendation would be to do an aging test of the individual battery cells. This would allow future researchers to see how the proprietary chemistry of the Tesla battery cells degraded over time. A correlation could be made between efficiency of the vehicle and the battery pack age.

To ensure that the measurements taken within this paper are accurate an uncertainty analysis should be performed. The uncertainty analysis would verify the recorded numbers. All measurements have an error associated with them, as the calculations are carried out the error can propagate throughout the answer. The errors associated with the measurement equipment (i.e. current clamp, and high voltage probe) were known. The uncertainty error associated with the dynamometer is unknown. To 
truly calculate the accuracy of the measurements within this document, the error of the dynamometer must also be known.

Lastly, an intentional controlled failure of a battery cell could be implemented. Intentionally creating a thermal runaway of a battery cell would allow future researchers to record mass flow rate of emissions from a battery cell, as well as analyze the species of gases emitted. 


\section{Bibliography}

[1] N. Omar, "Standardization Work for BEV and HEV Applications: Critical Appraisal of Recent Traction Battery Documents," MDPI Basel Switz.

[2] W. F. Infante, A. F. Khan, N. J. C. Libatique, G. L. Tangonan, and S. N. Y. Uy, "Performance evaluation of series hybrid and pure electric vehicles using lead-acid batteries and supercapacitors," in TENCON 2012 IEEE Region 10 Conference, 2012, pp. 1-5.

[3] K. A. Snyder, X. G. Yang, and T. J. Miller, "Hybrid Vehicle Battery Technology - The Transition From NiMH To Li-lon," 2009.

[4] "2013 Tesla Model S," Kbb.com. [Online]. Available: https://www.kbb.com/tesla/model-s/2013/. [Accessed: 27-Jul-2017].

[5] "Information about the Greenhouse Gas Emission Calculations." [Online]. Available: https://www.fueleconomy.gov/feg/label/calculations-information.shtml. [Accessed: 13-Jul-2017].

[6] O. US EPA, "Power Profiler," US EPA, 30-Jan-2015. [Online]. Available: https://www.epa.gov/energy/power-profiler. [Accessed: 13-Jul-2017].

[7] "Beyond Tailpipe Emissions: Results." [Online]. Available: https://www.fueleconomy.gov/feg/Find.do?zipCode=26505\&year=2017\&vehicleld=38557\&action=bt3. [Accessed: 13-Jul-2017].

[8] "Argonne GREET Model." [Online]. Available: https://greet.es.anl.gov/. [Accessed: 19-Jul-2017].

[9] "10 Best Luxury Large Cars | U.S. News \& World Report." [Online]. Available: https://cars.usnews.com/cars-trucks/rankings/luxury-large-cars. [Accessed: 22-Jun-2017].

[10] "Compare Side-by-Side." [Online]. Available: https://www.fueleconomy.gov/feg/Find.do?action=sbs\&id=38557\&id=37536\&id=37718. [Accessed: 13-Jul-2017].

[11] "Detailed Test Information." [Online]. Available: https://www.fueleconomy.gov/feg/fe_test_schedules.shtml. [Accessed: 27-Jul-2017].

[12] "Learn More About the Fuel Economy Label for Electric Vehicles." [Online]. Available: http://www.fueleconomy.gov/feg/label/learn-more-electric-label.shtml. [Accessed: 07-Jul-2017].

[13] G. Berdichevsky, K. Kelty, J. Straubel, and E. Toomre, "The Tesla Roadster Battery System."

[14] "Timeline: History of the Electric Car . NOW on PBS." [Online]. Available: http://www.pbs.org/now/shows/223/electric-car-timeline.html. [Accessed: 15-Jun-2017].

[15] J. Mercurio, "The General Motors Ev1 Interior."

[16] N. Kandasamy and S. Whelan, "Numerical Investigations of Vehicle Climate Control Strategies Impact on Plug-In Electrical Vehicle Battery Range," SAE Tech. Pap.

[17] "Numerical Investigations of Vehicle Climate Control Strategies Impact on Plug-In Electrical Vehicle Battery Range." [Online]. Available: http://papers.sae.org/2017-01-0190/. [Accessed: 22-Jun-2017].

[18] A. Lajunen, "Energy Efficiency and Performance of Cabin Thermal Management in Electric Vehicles," 2017.

[19] P. Zhou, "Electric Vehicle Thermal Management System," US 2010/0025006 A1.

[20] "Panasonic Delivers Over 100 Million Lithium-Ion Battery Cells for Tesla's Model S EV," Panasonic Newsroom Global. [Online]. Available: http://news.panasonic.com/global/topics/2013/22989.html. [Accessed: 22-Jun-2017].

[21] P. Wesskamp, S. Reitemeyer, and J. Melbert, "Online Capacity Estimation for Automotive Lithium-Ion Cells Incorporating Temperature-Variation and Cell-Aging," 2017.

[22] A. Augeard, T. Singo, P. Desprez, and M. Abbaoui, "Numerical methods for detecting DC arc fault in lithium-ion batteries," in 2015 IEEE 61st Holm Conference on Electrical Contacts (Holm), 2015, pp. $39-46$.

[23] N. Omar et al., "Assessment of performance of lithium iron phosphate oxide, nickel manganese cobalt oxide and nickel cobalt aluminum oxide based cells for using in plug-in battery electric vehicle applications," in 2011 IEEE Vehicle Power and Propulsion Conference, 2011, pp. 1-7.

[24] K. F. Yeow and H. Teng, "Characterizing Thermal Runaway of Lithium-ion Cells in a Battery System Using Finite Element Analysis Approach," SAE Int. J. Altern. Powertrains, vol. 2, no. 1, pp. 179-186, Apr. 2013. 
[25] "Battery Electric Vehicle Energy Consumption and Range Test Procedure (J1634 Ground Vehicle Standard) - SAE Mobilus." [Online]. Available: https://saemobilus.sae.org/content/j1634_201210. [Accessed: 22-Jun-2017].

[26] "UE9 Series | LabJack." [Online]. Available: https://labjack.com/products/ue9. [Accessed: 04-Jul2017].

[27] T. Dillard, "Look Inside A Tesla Model S Battery Pack," Inside EVs. [Online]. Available: http://insideevs.com/look-inside-a-tesla-model-s-battery-pac/. [Accessed: 04-Jul-2017].

[28] "Thermocouple," Omega. [Online]. Available: http://www.omega.com/prodinfo/thermocouples.html. [Accessed: 17-Jul-2017].

[29] "2016 Models S Emergency Responders Guide," Tesla. [Online]. Available:

https://www.tesla.com/sites/default/files/pdfs/first_responders/2016_Models_S_Emergency_Respond ers_Guide_en.pdf. [Accessed: 27-Jul-2017]. 


\section{Appendices}

\subsection{Appendix A}

\section{Panasonic \\ NCR18650B}

Features \& Benefits

- High energy density

- Long stable power and long run time

- Ideal for notebook PCs, boosters, portable devices, etc.

-At temperatures below $10^{\circ} \mathrm{C}$, charge at a $0.25 \mathrm{C}$ rate.

\section{Charge Characteristics}

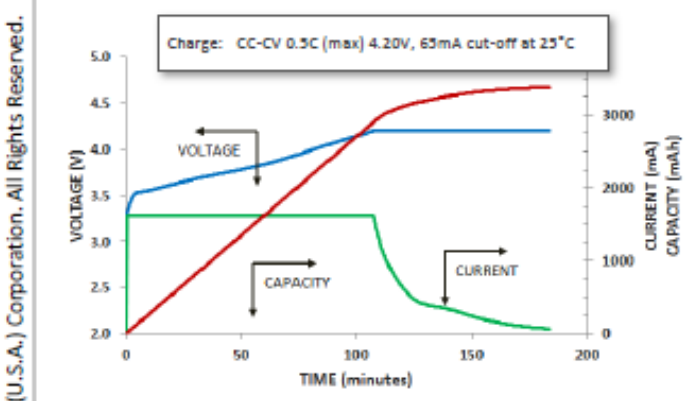

Discharge Characteristics (by temperature)

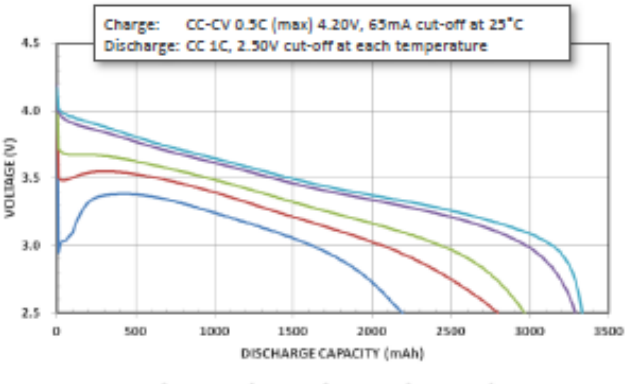

$-20^{\circ} \mathrm{c}-10^{\circ} \mathrm{c}-0^{*} \mathrm{c}-25^{\circ} \mathrm{c}-40^{\circ}$

The data in this document is for descriptive purposes only and is not intended to make or imply any guarantee or warranty.

For more information on how Panasonic can assist you with your battery power solution needs, visit us at www.panasonic.com/industrial/batteries-oem, e-mail secsales@us.panasonic.com, or call (469) 362-5600.
Dimensions

Max. $18.5 \mathrm{~mm}$

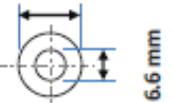

"With tube

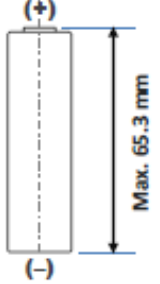

For Reference Only
Cycle Life Characteristics

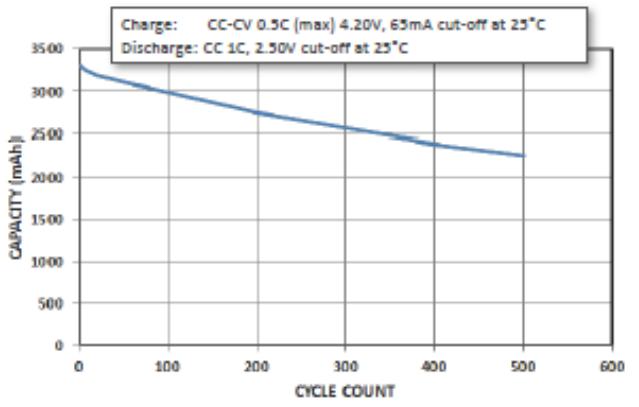

Discharge Characteristics (by rate of discharge)

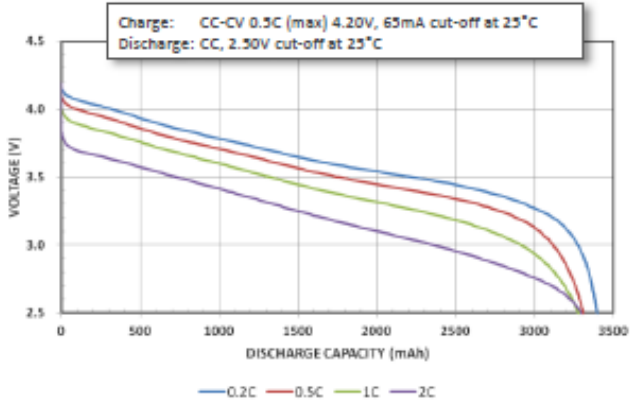




\subsection{Appendix B}

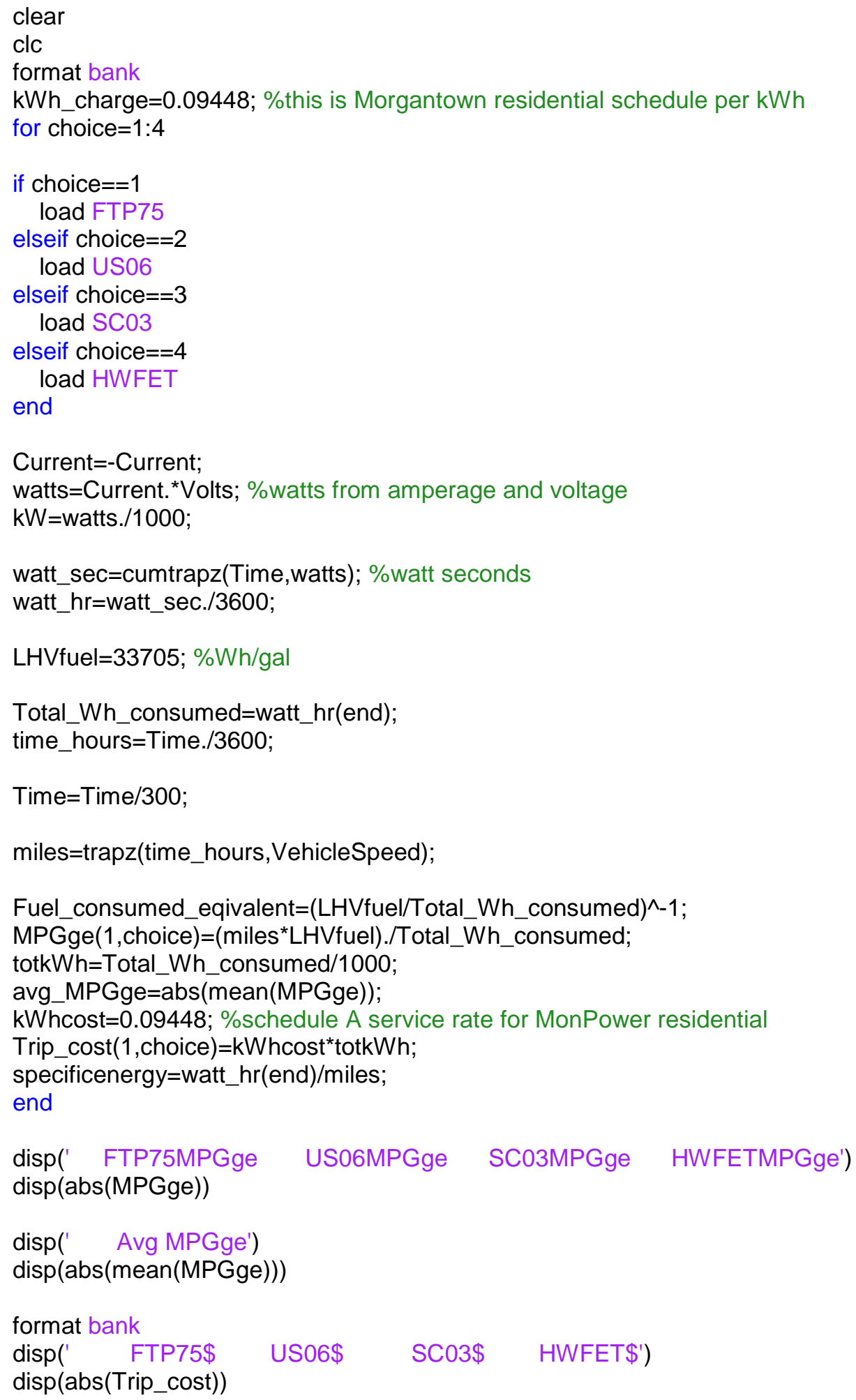




\subsection{Appendix C}

\begin{tabular}{|c|c|c|c|c|c|c|c|}
\hline & & & \multicolumn{5}{|c|}{ Volatile Organic Compounds plus C2-C4 Hydrocarbons } \\
\hline & & & \multicolumn{5}{|c|}{ Client Sample ID } \\
\hline & & & BLANK031017 & Air Control Sample 1 & Air Control Sample 2 & BATT 1 & BATT 2 W/O PUMP \\
\hline & CAS \# & COMPOUND NAME & \multicolumn{5}{|c|}{ Concentration (PPBV) } \\
\hline \multirow{23}{*}{ 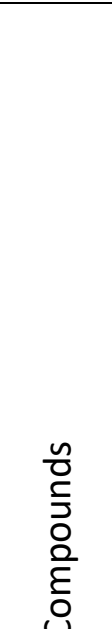 } & $115-07-1$ & PROPENE & $\mathrm{ND}(1.0)$ & $\mathrm{ND}(1.0)$ & $\mathrm{ND}(1.0)$ & $\mathrm{ND}(1.0)$ & 4.37 \\
\hline & $75-71-8$ & DICHLORODIFLUOROMETHANE & $\mathrm{ND}(1.0)$ & 0.595 & 0.677 & 0.426 & 0.529 \\
\hline & 74-87-3 & CHLOROMETHANE & $\mathrm{ND}(1.0)$ & 0.804 & 0.956 & 99.5 & 19 \\
\hline & $76-14-2$ & DICHLOROTETRAFLUOROETHANE & $\mathrm{ND}(1.0)$ & $\mathrm{ND}(1.0)$ & $\mathrm{ND}(1.0)$ & $\mathrm{ND}(1.0)$ & $\mathrm{ND}(1.0)$ \\
\hline & 63923 & VINYL CHLORIDE & $\mathrm{ND}(1.0)$ & $\mathrm{ND}(1.0)$ & $\mathrm{ND}(1.0)$ & 2.96 & 0.509 \\
\hline & 106-99-0 & 1,3-BUTADIENE & $\mathrm{ND}(1.0)$ & $\mathrm{ND}(1.0)$ & $\mathrm{ND}(1.0)$ & $\mathrm{ND}(1.0)$ & $\mathrm{ND}(1.0)$ \\
\hline & 74-83-9 & BROMOMETHANE & $\mathrm{ND}(1.0)$ & $\mathrm{ND}(1.0)$ & $\mathrm{ND}(1.0)$ & $\mathrm{ND}(1.0)$ & $\mathrm{ND}(1.0)$ \\
\hline & 64-17-5 & ETHANOL & $\mathrm{ND}(1.0)$ & 63 & 5.99 & 487 & 62.6 \\
\hline & $75-00-3$ & CHLOROETHANE & $\mathrm{ND}(1.0)$ & $\mathrm{ND}(1.0)$ & $\mathrm{ND}(1.0)$ & 2.55 & 0.43 \\
\hline & $107-02-8$ & ACROLEIN & $\mathrm{ND}(1.0)$ & 2.19 & $\mathrm{ND}(1.0)$ & 3.31 & 0.622 \\
\hline & 67-64-1 & ACETONE & $\mathrm{ND}(1.0)$ & 49.3 & 11.4 & 286 & 40.2 \\
\hline & 75-69-4 & TRICHLOROFLUOROMETHANE (R11) & $\mathrm{ND}(1.0)$ & 0.28 & 0.344 & $\mathrm{ND}(1.0)$ & 0.276 \\
\hline & 67-63-0 & ISOPROPANOL & $\mathrm{ND}(1.0)$ & 2.24 & $\mathrm{ND}(1.0)$ & 41.9 & 5.94 \\
\hline & 75-35-4 & 1,1-DICHLOROETHENE & $\mathrm{ND}(1.0)$ & $\mathrm{ND}(1.0)$ & $\mathrm{ND}(1.0)$ & $\mathrm{ND}(1.0)$ & $\mathrm{ND}(1.0)$ \\
\hline & 64164 & METHYLENE CHLORIDE & $\mathrm{ND}(1.0)$ & $\mathrm{ND}(1.0)$ & $\mathrm{ND}(1.0)$ & 7.29 & 1.43 \\
\hline & 76-13-1 & 1,1,2-TRICHLOROTRIFLUOROETHANE & $\mathrm{ND}(1.0)$ & $\mathrm{ND}(1.0)$ & $\mathrm{ND}(1.0)$ & $\mathrm{ND}(1.0)$ & $\mathrm{ND}(1.0)$ \\
\hline & $75-15-0$ & CARBON DISULFIDE & $\mathrm{ND}(1.0)$ & 2.29 & 0.898 & 7.89 & 1.27 \\
\hline & $156-60-5$ & trans-1,2-DICHLOROETHENE & $\mathrm{ND}(1.0)$ & $\mathrm{ND}(1.0)$ & $\mathrm{ND}(1.0)$ & 1.97 & 0.341 \\
\hline & \begin{tabular}{|l|}
$1634-04-4$ \\
\end{tabular} & METHYL TERT-BUTYL ETHER & $\mathrm{ND}(1.0)$ & $\mathrm{ND}(1.0)$ & $\mathrm{ND}(1.0)$ & $\mathrm{ND}(1.0)$ & 1.96 \\
\hline & $75-34-3$ & 1,1-DICHLOROETHANE & $\mathrm{ND}(1.0)$ & $\mathrm{ND}(1.0)$ & $\mathrm{ND}(1.0)$ & $\mathrm{ND}(1.0)$ & $\mathrm{ND}(1.0)$ \\
\hline & $108-05-4$ & VINYL ACETATE & $\mathrm{ND}(1.0)$ & $\mathrm{ND}(1.0)$ & $\mathrm{ND}(1.0)$ & $\mathrm{ND}(1.0)$ & $\mathrm{ND}(1.0)$ \\
\hline & $78-93-3$ & 2-BUTANONE & $\mathrm{ND}(1.0)$ & 2.47 & 0.397 & 4120 & 585 \\
\hline & $156-59-2$ & cis-1,2-DICHLOROETHENE & $\mathrm{ND}(1.0)$ & $\mathrm{ND}(1.0)$ & $\mathrm{ND}(1.0)$ & 2.69 & 0.363 \\
\hline \multirow{6}{*}{$\begin{array}{l}u \\
\text { 늠 } \\
\frac{c}{\sigma} \\
\text { ஸ் }\end{array}$} & $141-78-6$ & ETHYL ACETATE & $\mathrm{ND}(1.0)$ & $\mathrm{ND}(1.0)$ & $\mathrm{ND}(1.0)$ & $\mathrm{ND}(1.0)$ & $\mathrm{ND}(1.0)$ \\
\hline & $110-54-3$ & HEXANE & $\mathrm{ND}(1.0)$ & 0.201 & $\mathrm{ND}(1.0)$ & $\mathrm{ND}(1.0)$ & $\mathrm{ND}(1.0)$ \\
\hline & \begin{tabular}{|l|}
$67-66-3$ \\
\end{tabular} & CHLOROFORM & $\mathrm{ND}(1.0)$ & $\mathrm{ND}(1.0)$ & $\mathrm{ND}(1.0)$ & 41.2 & 7.81 \\
\hline & \begin{tabular}{|l|}
$109-99-9$ \\
\end{tabular} & TETRAHYDROFURAN & $\mathrm{ND}(1.0)$ & $\mathrm{ND}(1.0)$ & $\mathrm{ND}(1.0)$ & $\mathrm{ND}(1.0)$ & $\mathrm{ND}(1.0)$ \\
\hline & $107-06-2$ & 1,2-DICHLOROETHANE & $\mathrm{ND}(1.0)$ & $\mathrm{ND}(1.0)$ & $\mathrm{ND}(1.0)$ & $\mathrm{ND}(1.0)$ & $\mathrm{ND}(1.0)$ \\
\hline & \begin{tabular}{|l|}
$71-55-6$ \\
\end{tabular} & 1,1,1-TRICHLOROETHANE & $\mathrm{ND}(1.0)$ & $\mathrm{ND}(1.0)$ & $\mathrm{ND}(1.0)$ & $\mathrm{ND}(1.0)$ & $\mathrm{ND}(1.0)$ \\
\hline \multirow{3}{*}{$\frac{0}{\pi}$} & $71-43-2$ & BENZENE & $\mathrm{ND}(1.0)$ & 0.268 & $\mathrm{ND}(1.0)$ & 34.8 & 5.67 \\
\hline & $56-23-5$ & CARBON TETRACHLORIDE & $\mathrm{ND}(1.0)$ & $\mathrm{ND}(1.0)$ & $\mathrm{ND}(1.0)$ & 375 & 55.4 \\
\hline & \begin{tabular}{|l|}
$110-82-7$ \\
\end{tabular} & CYCLOHEXANE & $\mathrm{ND}(1.0)$ & $\mathrm{ND}(1.0)$ & $\mathrm{ND}(1.0)$ & $\mathrm{ND}(1.0)$ & $\mathrm{ND}(1.0)$ \\
\hline \multirow{32}{*}{ 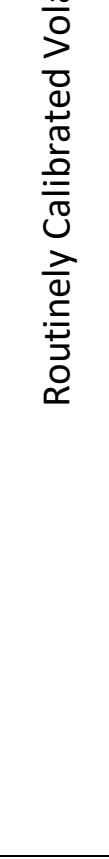 } & \begin{tabular}{|l|}
$78-87-5$ \\
\end{tabular} & 1,2-DICHLOROPROPANE & $\mathrm{ND}(1.0)$ & $\mathrm{ND}(1.0)$ & $\mathrm{ND}(1.0)$ & $\mathrm{ND}(1.0)$ & $\mathrm{ND}(1.0)$ \\
\hline & $75-27-4$ & BROMODICHLOROMETHANE & $\mathrm{ND}(1.0)$ & $\mathrm{ND}(1.0)$ & $\mathrm{ND}(1.0)$ & $\mathrm{ND}(1.0)$ & $\mathrm{ND}(1.0)$ \\
\hline & 65386 & TRICHLOROETHENE & $\mathrm{ND}(1.0)$ & $\mathrm{ND}(1.0)$ & $\mathrm{ND}(1.0)$ & 340 & 55.2 \\
\hline & \begin{tabular}{|l|}
$123-91-1$ \\
\end{tabular} & 1,4-DIOXANE & $\mathrm{ND}(1.0)$ & $\mathrm{ND}(1.0)$ & $\mathrm{ND}(1.0)$ & 3.92 & $\mathrm{ND}(1.0)$ \\
\hline & $80-62-6$ & METHYL METHACRYLATE & $\mathrm{ND}(1.0)$ & $\mathrm{ND}(1.0)$ & $\mathrm{ND}(1.0)$ & 2270 & 310 \\
\hline & $142-82-5$ & HEPTANE & $\mathrm{ND}(1.0)$ & 0.695 & 0.439 & $\mathrm{ND}(1.0)$ & 3.84 \\
\hline & $108-10-1$ & 4-METHYL-2-PENTANONE & $\mathrm{ND}(1.0)$ & 3.1 & 0.509 & $\mathrm{ND}(1.0)$ & 1.34 \\
\hline & 10061-01-5 & cis-1,3-DICHLOROPROPENE & $\mathrm{ND}(1.0)$ & $\mathrm{ND}(1.0)$ & $\mathrm{ND}(1.0)$ & $\mathrm{ND}(1.0)$ & $\mathrm{ND}(1.0)$ \\
\hline & 10061-02-6 & trans-1,3-DICHLOROPROPENE & $\mathrm{ND}(1.0)$ & $\mathrm{ND}(1.0)$ & $\mathrm{ND}(1.0)$ & $\mathrm{ND}(1.0)$ & $\mathrm{ND}(1.0)$ \\
\hline & $79-00-5$ & 1,1,2-TRICHLOROETHANE & $\mathrm{ND}(1.0)$ & $\mathrm{ND}(1.0)$ & $\mathrm{ND}(1.0)$ & $\mathrm{ND}(1.0)$ & $\mathrm{ND}(1.0)$ \\
\hline & 108-88-3 & TOLUENE & $\mathrm{ND}(1.0)$ & 1.91 & 0.889 & 57.2 & 8.69 \\
\hline & $591-78-6$ & 2-HEXANONE & $\mathrm{ND}(1.0)$ & $\mathrm{ND}(1.0)$ & $\mathrm{ND}(1.0)$ & $\mathrm{ND}(1.0)$ & $\mathrm{ND}(1.0)$ \\
\hline & $124-48-1$ & DIBROMOCHLOROMETHANE & $\mathrm{ND}(1.0)$ & $\mathrm{ND}(1.0)$ & $\mathrm{ND}(1.0)$ & $\mathrm{ND}(1.0)$ & $\mathrm{ND}(1.0)$ \\
\hline & \begin{tabular}{|l|}
$106-93-4$ \\
\end{tabular} & 1,2-DIBROMOETHANE & $\mathrm{ND}(1.0)$ & $\mathrm{ND}(1.0)$ & $\mathrm{ND}(1.0)$ & $\mathrm{ND}(1.0)$ & $\mathrm{ND}(1.0)$ \\
\hline & $127-18-4$ & TETRACHLOROETHENE & $\mathrm{ND}(1.0)$ & $\mathrm{ND}(1.0)$ & $\mathrm{ND}(1.0)$ & 9430 & 1100 \\
\hline & \begin{tabular}{|l|}
$108-90-7$ \\
\end{tabular} & CHLOROBENZENE & $\mathrm{ND}(1.0)$ & $\mathrm{ND}(1.0)$ & $\mathrm{ND}(1.0)$ & $\mathrm{ND}(1.0)$ & 0.324 \\
\hline & $100-41-4$ & ETHYLBENZENE & $\mathrm{ND}(1.0)$ & 2.25 & 0.631 & 6.99 & 1.55 \\
\hline & & M/P-XYLENE & $\mathrm{ND}(1.0)$ & 9.37 & 2.67 & 27.3 & 6.38 \\
\hline & \begin{tabular}{|l|}
$75-25-2$ \\
\end{tabular} & BROMOFORM & $\mathrm{ND}(1.0)$ & $\mathrm{ND}(1.0)$ & $\mathrm{ND}(1.0)$ & $\mathrm{ND}(1.0)$ & $\mathrm{ND}(1.0)$ \\
\hline & $100-42-5$ & STYRENE & $\mathrm{ND}(1.0)$ & $\mathrm{ND}(1.0)$ & $\mathrm{ND}(1.0)$ & $\mathrm{ND}(1.0)$ & $\mathrm{ND}(1.0)$ \\
\hline & \begin{tabular}{|l|}
$79-34-5$ \\
\end{tabular} & 1,1,2,2-TETRACHLOROETHANE & $\mathrm{ND}(1.0)$ & $\mathrm{ND}(1.0)$ & $\mathrm{ND}(1.0)$ & $\mathrm{ND}(1.0)$ & $\mathrm{ND}(1.0)$ \\
\hline & \begin{tabular}{|l|}
$95-47-6$ \\
\end{tabular} & O-XYLENE & $\mathrm{ND}(1.0)$ & 3.39 & 0.95 & 6.36 & 1.35 \\
\hline & \begin{tabular}{|l|}
$622-96-8$ \\
\end{tabular} & 4-ETHYLTOLUENE & $\mathrm{ND}(1.0)$ & 0.562 & 0.346 & $\mathrm{ND}(1.0)$ & $\mathrm{ND}(1.0)$ \\
\hline & \begin{tabular}{|l|}
$108-67-8$ \\
\end{tabular} & 1,3,5-TRIMETHYLBENZENE & $\mathrm{ND}(1.0)$ & 0.51 & 0.207 & 0.779 & $\mathrm{ND}(1.0)$ \\
\hline & $95-63-6$ & 1,2,4-TRIMETHYLBENZENE & $\mathrm{ND}(1.0)$ & 1.61 & 0.723 & 2.93 & 0.514 \\
\hline & $100-44-7$ & BENZYL CHLORIDE & $\mathrm{ND}(1.0)$ & $\mathrm{ND}(1.0)$ & $\mathrm{ND}(1.0)$ & $\mathrm{ND}(1.0)$ & $\mathrm{ND}(1.0)$ \\
\hline & 541-73-1 & 1,3-DICHLOROBENZENE & $\mathrm{ND}(1.0)$ & $\mathrm{ND}(1.0)$ & $\mathrm{ND}(1.0)$ & $\mathrm{ND}(1.0)$ & $\mathrm{ND}(1.0)$ \\
\hline & $106-46-7$ & 1,4-DICHLOROBENZENE & $\mathrm{ND}(1.0)$ & $\mathrm{ND}(1.0)$ & $\mathrm{ND}(1.0)$ & $\mathrm{ND}(1.0)$ & $\mathrm{ND}(1.0)$ \\
\hline & \begin{tabular}{|l|}
$95-50-1$ \\
\end{tabular} & 1,2-DICHLOROBENZENE & $\mathrm{ND}(1.0)$ & $\mathrm{ND}(1.0)$ & $\mathrm{ND}(1.0)$ & $\mathrm{ND}(1.0)$ & $\mathrm{ND}(1.0)$ \\
\hline & $120-82-1$ & 1,2,4-TRICHLOROBENZENE & $\mathrm{ND}(1.0)$ & 0.351 & $\mathrm{ND}(1.0)$ & $\mathrm{ND}(1.0)$ & $\mathrm{ND}(1.0)$ \\
\hline & $91-20-3$ & NAPHTHALENE & $\mathrm{ND}(1.0)$ & 0.518 & $\mathrm{ND}(1.0)$ & $\mathrm{ND}(1.0)$ & $\mathrm{ND}(1.0)$ \\
\hline & $87-68-3$ & HEXACHLOROBUTADIENE & $\mathrm{ND}(1.0)$ & $\mathrm{ND}(1.0)$ & $\mathrm{ND}(1.0)$ & 0.548 & $\mathrm{ND}(1.0)$ \\
\hline \multirow{4}{*}{ 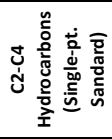 } & 74-98-6 & PROPANE & ND & ND & 2 & 29 & 6.73 \\
\hline & $75-28-5$ & ISOBUTANE & ND & 0.469 & 0.811 & 1.91 & 0.638 \\
\hline & $106-97-8$ & BUTANE & ND & 0.522 & 1.58 & 5.63 & 1.79 \\
\hline & 74-84-0 & ETHANE & ND & ND & ND & ND & ND \\
\hline & & \multicolumn{3}{|c|}{${ }^{*} \mathrm{ND}(\mathrm{X})$ - Analyte not detected; associated detection limit is given. } & & & \\
\hline
\end{tabular}




\subsection{Appendix D}

\begin{tabular}{|c|c|c|c|c|c|c|}
\hline & & & \multicolumn{4}{|c|}{ Volatile Organic Compounds plus C2-C4 Hydrocarbons } \\
\hline & & SwRI System ID & 613513 & 613514 & 613515 & 613516 \\
\hline & & Client ID & Super Charger 1 No Pump & Super Charger 2 No Pump & Travel to Coopers Rock & Travel to Super Charge \\
\hline & CAS \# & COMPOUND NAME & \multicolumn{4}{|c|}{ Concentration (PPBV) } \\
\hline & $115-07-1$ & PROPENE & $\mathrm{ND}(10.0)$ & $\mathrm{ND}(10.0)$ & $\mathrm{ND}(10.0)$ & $\mathrm{ND}(10.0)$ \\
\hline \multirow{23}{*}{ 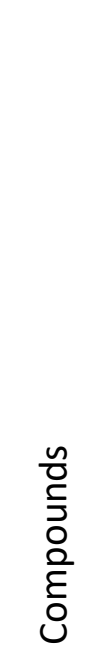 } & $75-71-8$ & DICHLORODIFLUOROMETHANE & $\mathrm{ND}(10.0)$ & $\mathrm{ND}(10.0)$ & $\mathrm{ND}(10.0)$ & $\mathrm{ND}(10.0)$ \\
\hline & $74-87-3$ & CHLOROMETHANE & 436 & 446 & 197 & 340 \\
\hline & $76-14-2$ & DICHLOROTETRAFLUOROETHANE & $\mathrm{ND}(10.0)$ & $\mathrm{ND}(10.0)$ & $\mathrm{ND}(10.0)$ & $\mathrm{ND}(10.0)$ \\
\hline & 75-01-4 & VINYL CHLORIDE & 5.15 & 5 & 2.4 & 4.01 \\
\hline & 106-99-0 & 1,3-BUTADIENE & $\mathrm{ND}(10.0)$ & $\mathrm{ND}(10.0)$ & $\mathrm{ND}(10.0)$ & $\mathrm{ND}(10.0)$ \\
\hline & $74-83-9$ & BROMOMETHANE & $\mathrm{ND}(10.0)$ & $\mathrm{ND}(10.0)$ & $\mathrm{ND}(10.0)$ & $\mathrm{ND}(10.0)$ \\
\hline & $64-17-5$ & ETHANOL & 1530 & 1180 & 665 & 1220 \\
\hline & $75-00-3$ & CHLOROETHANE & 16.3 & 17.1 & 5.66 & 10.2 \\
\hline & $107-02-8$ & ACROLEIN & $\mathrm{ND}(10.0)$ & $\mathrm{ND}(10.0)$ & $\mathrm{ND}(10.0)$ & $\mathrm{ND}(10.0)$ \\
\hline & $67-64-1$ & ACETONE & 3390 & 786 & 1490 & 680 \\
\hline & $75-69-4$ & TRICHLOROFLUOROMETHANE (R11) & $\mathrm{ND}(10.0)$ & $\mathrm{ND}(10.0)$ & $\mathrm{ND}(10.0)$ & $\mathrm{ND}(10.0)$ \\
\hline & $67-63-0$ & ISOPROPANOL & 200 & 156 & 52.8 & 98.3 \\
\hline & 75-35-4 & 1,1-DICHLOROETHENE & $\mathrm{ND}(10.0)$ & $\mathrm{ND}(10.0)$ & $\mathrm{ND}(10.0)$ & $\mathrm{ND}(10.0)$ \\
\hline & 75-09-2 & METHYLENE CHLORIDE & $\mathrm{ND}(10.0)$ & $\mathrm{ND}(10.0)$ & $\mathrm{ND}(10.0)$ & $\mathrm{ND}(10.0)$ \\
\hline & 76-13-1 & 1,1,2-TRICHLOROTRIFLUOROETHANE & $\mathrm{ND}(10.0)$ & $\mathrm{ND}(10.0)$ & $\mathrm{ND}(10.0)$ & $\mathrm{ND}(10.0)$ \\
\hline & $75-15-0$ & CARBON DISULFIDE & 15 & 12.4 & 5.41 & 8.15 \\
\hline & $156-60-5$ & trans-1,2-DICHLOROETHENE & $\mathrm{ND}(10.0)$ & $\mathrm{ND}(10.0)$ & $\mathrm{ND}(10.0)$ & $\mathrm{ND}(10.0)$ \\
\hline & 1634-04-4 & METHYL TERT-BUTYL ETHER & $\mathrm{ND}(10.0)$ & $\mathrm{ND}(10.0)$ & $\mathrm{ND}(10.0)$ & $\mathrm{ND}(10.0)$ \\
\hline & $75-34-3$ & 1,1-DICHLOROETHANE & $\mathrm{ND}(10.0)$ & $\mathrm{ND}(10.0)$ & $\mathrm{ND}(10.0)$ & ND(10.0) \\
\hline & $108-05-4$ & VINYL ACETATE & $\mathrm{ND}(10.0)$ & $\mathrm{ND}(10.0)$ & $\mathrm{ND}(10.0)$ & $\mathrm{ND}(10.0)$ \\
\hline & $78-93-3$ & 2-BUTANONE & 7120 & 5690 & 3560 & 5090 \\
\hline & $156-59-2$ & cis-1,2-DICHLOROETHENE & 4.23 & $\mathrm{ND}(10.0)$ & $\mathrm{ND}(10.0)$ & $\mathrm{ND}(10.0)$ \\
\hline & $141-78-6$ & ETHYL ACETATE & $\mathrm{ND}(10.0)$ & $\mathrm{ND}(10.0)$ & $\mathrm{ND}(10.0)$ & $\mathrm{ND}(10.0)$ \\
\hline \multirow{5}{*}{ 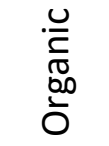 } & $110-54-3$ & HEXANE & $\mathrm{ND}(10.0)$ & $\mathrm{ND}(10.0)$ & $\mathrm{ND}(10.0)$ & $\mathrm{ND}(10.0)$ \\
\hline & $67-66-3$ & CHLOROFORM & 49.6 & 43.2 & 25.1 & 33.8 \\
\hline & $109-99-9$ & TETRAHYDROFURAN & $\mathrm{ND}(10.0)$ & $\mathrm{ND}(10.0)$ & $\mathrm{ND}(10.0)$ & $\mathrm{ND}(10.0)$ \\
\hline & 107-06-2 & 1,2-DICHLOROETHANE & $\mathrm{ND}(10.0)$ & $\mathrm{ND}(10.0)$ & $\mathrm{ND}(10.0)$ & $\mathrm{ND}(10.0)$ \\
\hline & $71-55-6$ & 1,1,1-TRICHLOROETHANE & $\mathrm{ND}(10.0)$ & $\mathrm{ND}(10.0)$ & $\mathrm{ND}(10.0)$ & $\mathrm{ND}(10.0)$ \\
\hline \multirow{3}{*}{$\frac{\Phi}{\pi}$} & 71-43-2 & BENZENE & 58 & 53 & 21.9 & 35.9 \\
\hline & $56-23-5$ & CARBON TETRACHLORIDE & 317 & 281 & 127 & 189 \\
\hline & $110-82-7$ & CYCLOHEXANE & $\mathrm{ND}(10.0)$ & $\mathrm{ND}(10.0)$ & $\mathrm{ND}(10.0)$ & $\mathrm{ND}(10.0)$ \\
\hline \multirow{2}{*}{$\stackrel{0}{>}$} & 78-87-5 & 1,2-DICHLOROPROPANE & $\mathrm{ND}(10.0)$ & $\mathrm{ND}(10.0)$ & $\mathrm{ND}(10.0)$ & $\mathrm{ND}(10.0)$ \\
\hline & $75-27-4$ & BROMODICHLOROMETHANE & $\mathrm{ND}(10.0)$ & $\mathrm{ND}(10.0)$ & $\mathrm{ND}(10.0)$ & $\mathrm{ND}(10.0)$ \\
\hline \multirow{30}{*}{ 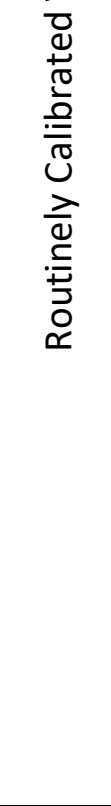 } & $79-01-6$ & TRICHLOROETHENE & 428 & 392 & 156 & 248 \\
\hline & 123-91-1 & 1,4-DIOXANE & $\mathrm{ND}(10.0)$ & $\mathrm{ND}(10.0)$ & $\mathrm{ND}(10.0)$ & $\mathrm{ND}(10.0)$ \\
\hline & $80-62-6$ & METHYL METHACRYLATE & 5340 & 4680 & 2900 & 4880 \\
\hline & $142-82-5$ & HEPTANE & $\mathrm{ND}(10.0)$ & 34.4 & 14.1 & 22.4 \\
\hline & $108-10-1$ & 4-METHYL-2-PENTANONE & 6.78 & 6.45 & $\mathrm{ND}(10.0)$ & 4.14 \\
\hline & 10061-01-5 & cis-1,3-DICHLOROPROPENE & $\mathrm{ND}(10.0)$ & $\mathrm{ND}(10.0)$ & $\mathrm{ND}(10.0)$ & $\mathrm{ND}(10.0)$ \\
\hline & 10061-02-6 & trans-1,3-DICHLOROPROPENE & $\mathrm{ND}(10.0)$ & $\mathrm{ND}(10.0)$ & $\mathrm{ND}(10.0)$ & $\mathrm{ND}(10.0)$ \\
\hline & 79-00-5 & 1,1,2-TRICHLOROETHANE & $\mathrm{ND}(10.0)$ & $\mathrm{ND}(10.0)$ & $\mathrm{ND}(10.0)$ & $\mathrm{ND}(10.0)$ \\
\hline & 108-88-3 & TOLUENE & 246 & 145 & 87 & 89.9 \\
\hline & 591-78-6 & 2-HEXANONE & $\mathrm{ND}(10.0)$ & $\mathrm{ND}(10.0)$ & $\mathrm{ND}(10.0)$ & $\mathrm{ND}(10.0)$ \\
\hline & \begin{tabular}{|l|}
$124-48-1$ \\
\end{tabular} & DIBROMOCHLOROMETHANE & $\mathrm{ND}(10.0)$ & $\mathrm{ND}(10.0)$ & $\mathrm{ND}(10.0)$ & $\mathrm{ND}(10.0)$ \\
\hline & \begin{tabular}{|l|}
$106-93-4$ \\
\end{tabular} & 1,2-DIBROMOETHANE & $\mathrm{ND}(10.0)$ & $\mathrm{ND}(10.0)$ & $\mathrm{ND}(10.0)$ & $\mathrm{ND}(10.0)$ \\
\hline & $127-18-4$ & TETRACHLOROETHENE & 6940 & 6970 & 2200 & 2500 \\
\hline & $108-90-7$ & CHLOROBENZENE & 4.61 & 5.18 & $\mathrm{ND}(10.0)$ & 3.55 \\
\hline & $100-41-4$ & ETHYLBENZENE & 5.71 & 5.17 & 5.74 & 3.07 \\
\hline & & M/P-XYLENE & 16.3 & 13.3 & 24.5 & 7.87 \\
\hline & $75-25-2$ & BROMOFORM & $\mathrm{ND}(10.0)$ & $\mathrm{ND}(10.0)$ & $\mathrm{ND}(10.0)$ & $\mathrm{ND}(10.0)$ \\
\hline & $100-42-5$ & STYRENE & $\mathrm{ND}(10.0)$ & $\mathrm{ND}(10.0)$ & $\mathrm{ND}(10.0)$ & $\mathrm{ND}(10.0)$ \\
\hline & 79-34-5 & 1,1,2,2-TETRACHLOROETHANE & $\mathrm{ND}(10.0)$ & $\mathrm{ND}(10.0)$ & $\mathrm{ND}(10.0)$ & $\mathrm{ND}(10.0)$ \\
\hline & $95-47-6$ & O-XYLENE & 5.78 & 4.88 & 17.5 & 2.84 \\
\hline & $622-96-8$ & 4-ETHYLTOLUENE & $\mathrm{ND}(10.0)$ & $\mathrm{ND}(10.0)$ & $\mathrm{ND}(10.0)$ & $\mathrm{ND}(10.0)$ \\
\hline & $108-67-8$ & 1,3,5-TRIMETHYLBENZENE & $\mathrm{ND}(10.0)$ & $\mathrm{ND}(10.0)$ & 3.17 & $\mathrm{ND}(10.0)$ \\
\hline & $95-63-6$ & 1,2,4-TRIMETHYLBENZENE & $\mathrm{ND}(10.0)$ & $\mathrm{ND}(10.0)$ & 11.2 & 2.78 \\
\hline & $100-44-7$ & BENZYL CHLORIDE & $\mathrm{ND}(10.0)$ & $\mathrm{ND}(10.0)$ & $\mathrm{ND}(10.0)$ & $\mathrm{ND}(10.0)$ \\
\hline & $541-73-1$ & 1,3-DICHLOROBENZENE & $\mathrm{ND}(10.0)$ & $\mathrm{ND}(10.0)$ & $\mathrm{ND}(10.0)$ & $\mathrm{ND}(10.0)$ \\
\hline & $106-46-7$ & 1,4-DICHLOROBENZENE & $\mathrm{ND}(10.0)$ & $\mathrm{ND}(10.0)$ & $\mathrm{ND}(10.0)$ & $\mathrm{ND}(10.0)$ \\
\hline & $95-50-1$ & 1,2-DICHLOROBENZENE & $\mathrm{ND}(10.0)$ & $\mathrm{ND}(10.0)$ & $\mathrm{ND}(10.0)$ & $\mathrm{ND}(10.0)$ \\
\hline & $120-82-1$ & 1,2,4-TRICHLOROBENZENE & $\mathrm{ND}(10.0)$ & $\mathrm{ND}(10.0)$ & $\mathrm{ND}(10.0)$ & $\mathrm{ND}(10.0)$ \\
\hline & $91-20-3$ & NAPHTHALENE & $\mathrm{ND}(10.0)$ & $\mathrm{ND}(10.0)$ & $\mathrm{ND}(10.0)$ & $\mathrm{ND}(10.0)$ \\
\hline & $87-68-3$ & HEXACHLOROBUTADIENE & $\mathrm{ND}(10.0)$ & $\mathrm{ND}(10.0)$ & $\mathrm{ND}(10.0)$ & $\mathrm{ND}(10.0)$ \\
\hline \multirow{4}{*}{ 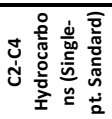 } & $74-98-6$ & PROPANE & 685 & 799 & 409 & 572 \\
\hline & \begin{tabular}{|l|}
$75-28-5$ \\
\end{tabular} & ISOBUTANE & 26.1 & 24.1 & 12.6 & 17.3 \\
\hline & 106-97-8 & BUTANE & 114 & 121 & 57.5 & 86.8 \\
\hline & 74-84-0 & ETHANE & 17600 & 27300 & 10300 & 13000 \\
\hline
\end{tabular}

